Lúcia Galvão Gomes dos Reis Ramos

\title{
A Performance da Luz no contexto de Intervenções Urbanas
}

São Paulo

2019 
Lúcia Galvão Gomes dos Reis Ramos

\section{A Performance da Luz no contexto de Intervenções Urbanas}

Dissertação apresentada ao Programa de Pós-Graduação em Artes Cênicas da Escola de Comunicações e Artes da Universidade de São Paulo para obtenção do título de Mestre em Artes Cênicas.

Área de concentração: Teoria e Prática do Teatro.

Linha de pesquisa: Texto e Cena

Orientadora: Prof. Dra. Cibele Forjaz Simões

São Paulo

2019 
AUTORIZO A REPRODUÇÃO E DIVULGAÇÃO TOTAL OU PARCIAL DESTE TRABALHO, POR QUALQUER MEIO CONVENCIONAL OU ELETRÔNICO, PARA FINS DE ESTUDO E PESQUISA, DESDE QUE CITADA A FONTE.

RAMOS, Lúcia Galvão Gomes dos Reis

A performance da luz no contexto de intervenções urbanas/ Lúcia Galvão Gomes dos Reis Ramos; orientadora, Cibele Forjaz Simões. São Paulo, 2019.106 p.:il.

Dissertação (Mestrado) - Programa de Pós-Graduação em Artes Cênicas - Escola de Comunicações e Artes / Universidade de São Paulo.

Bibliografia

Versão original

1.Iluminação 2. Intervenção Urbana 3. Cor 4. Arte Urbana

I. Forjaz Simões, Cibele II. Título.

CDD 21.ed. - 792 
Lúcia Galvão Gomes dos Reis Ramos

A Performance da Luz no contexto de Intervenções Urbanas

Dissertação apresentada ao Programa de Pós-Graduação em Artes Cênicas da Escola de Comunicações e Artes da

Universidade de São Paulo para obtenção do título de Mestre em Artes Cênicas.

Aprovada em:

Banca Examinadora:

Prof. Dr. :

Instituição:

Assinatura:

Prof. Dr. :

Instituição:

Assinatura:

Prof. Dr. :

Instituição:

Assinatura: 
Dedico essa dissertação à Clara, Quilha e Nando. 


\section{AGRADECIMENTOS}

Em primeiro lugar gostaria de agradecer minha orientadora, Cibele Forjaz, pela confiança e principalmente por ter aberto os caminhos para que essa e outras pesquisas sobre iluminação pudessem ter espaço em nosso meio acadêmico. Sem dúvida ela estabeleceu um novo patamar para os estudos sobre luz no Brasil e é com imensa alegria que me junto a uma primeira leva de orientandos dedicados ao tema.

Não poderia deixar de agradecer a meu mestre Guilherme Bonfanti, pelo que ele significou dentro da minha formação, pela inspiração e pela generosidade que teve comigo ao longo desse processo de mestrado, me recebendo em sua casa e disponibilizando toda a sorte de materiais para a pesquisa. Também não tenho palavras para expressar minha gratidão pela atenção e gentileza da artista Eleonora Fabião que foi fundamental para o resultado dessa investigação. Além de sua obra ter sido uma das principais inspirações para a dissertação, suas contribuições na banca de qualificação e a forma aguçada com que ela olhou para o projeto foram decisivos.

Essa dissertação não teria se realizado sem o suporte e carinho da minha família, que sempre me apoiou incondicionalmente e me ajudou de inúmeras formas a tornar possível essa realização. Especialmente minha irmã Clara, a quem não tenho palavras para agradecer todas as leituras e revisões cuidadosas, fundamentais para chegar até aqui.

Por fim gostaria de agradecer todos os colegas que participaram de diferentes formas dos projetos citados, são tantos que ficaria impossível citar aqui todos sem cometer alguma injustiça. Mas, em especial agradeço à: Guilherme Tanaka que me ajudou com a construção da maquete do projeto, Emiliano Capozoli pelo registro cuidadoso de tantos trabalhos e Helena Musa que me ajudou com a formatação desse texto. 
8 INTRODUÇÃO

11 PARTE 1: COR

24 PARTE 2: CIDADE

$27 \quad 2.1$ A fisiologia da luz nas performances de Eleonora Fabião.

$50 \quad 2.2$ A experiência com a luz da cidade em Bom Retiro 985 metros.

67 PARTE 3: AÇÕES

$67 \quad 3.1$ Breve genealogia

813.20 Bixiga

101 CONSIDERAÇÕES FINAIS

102 BIBLIOGRAFIA 


\title{
RESUMO
}

Esse trabalho investiga o potencial performativo da luz dentro do contexto das intervenções urbanas, a partir da análise de obras desenvolvidas por artistas brasileiros de teatro e das artes visuais. A pesquisa propõe uma aproximação entre estes dois campos artísticos tendo como apoio duas referencias teóricas fundamentais: Goethe e Hélio Oiticica. Nessa perspectiva, algumas instalações urbanas realizadas pela autora entre 2005 e 2008, em São Paulo, foram revisitadas. Na tentativa de estabelecer diálogos com os artistas explorados na pesquisa o projeto se desenvolve também em uma dimensão prática, que resulta em uma nova proposta de intervenção urbana em São Paulo.

\begin{abstract}
This work investigates the performative potential of light within the context of urban interventions based on the poetics of different Brazilian theatre and visual artists. The research proposes an approximation between these two artistic fields having as a support the work of two fundamental theoretical references: Goethe and Hélio Oiticica. In this perspective, some urban interventions created by the author in São Paulo, between 2005 and 2008, were revisited. In the attempt of establishing relations with the researched artists the project develops itself also in a practical dimension, which results in a new proposal of urban intervention in São Paulo.
\end{abstract}




\section{INTRODUÇÃO}

O texto apresentado se propôs a investigar experiências visuais no campo da iluminação desenvolvidas por artistas de teatro e das artes visuais, na tentativa de aproximar os dois campos por meio de uma linguagem comum: a luz, enquanto ferramenta de performances e intervenções urbanas. A partir da premissa de que existe uma área comum nas pesquisas em iluminação e nas relações que são estabelecidas com a paisagem através da percepção visual e da experiência corporal, busca-se uma aproximação entre a produção dos artistas que operam nas artes plásticas e no campo teatral com a intenção de uma análise da minha própria produção artística.

0 eixo central da investigação se deu pelo foco na relação estabelecida entre o olho humano, a luz e o espaço. A compreensão da arte enquanto uma experiência e do espaço como fator determinante na relação entre obra e espectador foi o que direcionou o recorte dos artistas selecionados para estudo, e que servem de base para as reflexões que culminarão do último capítulo da dissertação. De forma que a primeira parte desse trabalho foca em um certo entendimento da cor e da luz, a ser perseguido ao longo da dissertação, e tendo como eixo principal duas obras teóricas: 1- "O Aspiro ao grande labirinto" de Hélio Oiticica, 2- "Doutrina das Cores" de Goethe; além da experiência de outros artistas plásticos que aprofundaram uma pesquisa nesse campo de cor e luz, como por exemplo Yves Klein e James Turrel.

A segunda parte tem como objetivo abordar obras que relacionam-se com a cidade a partir da experiência com a luz. Ao longo da pesquisa, a ênfase por uma perspectiva relacionada à arte urbana foi se aprofundando e determinou a seleção de obras que tem como questão central a problematização com o espaço urbano. Nesse sentido, far-se-á uma breve apresentação das referências teóricas que orientaram a natureza dessa dimensão política da pesquisa, entre as quais destacam-se os textos "A vida cotidiana no Mundo Moderno", de Henri Lefebvre, e “ Arte, Cultura e Cidade: aspectos estético-políticos contemporâneos", de Vera Pallamin. É a partir desse pano de fundo que se apresentará uma reflexão sobre determinados trabalhos dos artistas Eleonora Fabião e Guilherme Bonfanti.

A artista carioca realiza ações e performa na rua desde 2008, e também atua como professora da Pós-Graduação em Artes da Cena na UFRJ. A escolha dessa artista está relacionada ao potencial sensível desses trabalhos - que investigam a relação com o espaço a partir da luz - e também ao agudo sentido político de sua obra na experiência com a cidade. Além disso, a artista tem produzido um rico material reflexivo e teórico que embasa suas ações e propõe questões muito significativas acerca da dimensão do trabalho de intervenção urbana. A partir do entendimento do artista performer como alguém que busca inaugurar a abertura de novos espaços dentro do espaço normatizado pelo cotidiano, ela estabelece fissuras na tessitura da experiência urbana. 
Em seguida, pretende-se relacionar as questões suscitadas pela artista por meio dessas proposições com o trabalho do iluminador Guilherme Bonfanti, em especial o projeto 'Bom Retiro 958', espetáculo teatral encenado pelo Teatro da Vertigem no bairro do Bom Retiro, em São Paulo, no ano de 2012. 0 espetáculo escolhido é uma realização extremamente interessante no que se refere à experiência com o espaço urbano, especialmente no que se refere ao projeto de luz, que tem um enorme protagonismo na linguagem do espetáculo, incorporando táticas e operações de ação direta na cidade. 0 tipo de solução que é dado por Bonfanti para as questões técnicas que envolvem o desenho de luz do espetáculo e a sua escolha de materiais aproximam-se do entendimento que Fabião tem da luz como ferramenta de trabalho. Os projetos de luz de Bonfanti - desenvolvidos no Teatro de Vertigem - tem a marca de incorporar conceitualmente e esteticamente as condições muitas vezes adversas, tanto do meio e da paisagem, quanto das limitações econômicas, o que geralmente resulta em soluções altamente criativas. Nesse sentido, aproximo as práticas desses dois artistas que - nas palavras de Fabião - utilizam-se da precariedade, no melhor sentido do termo, para seu fazer artístico.

Como já foi dito, é também intenção dessa pesquisa culminar, na terceira parte, com uma atualização do meu próprio fazer artístico. Nessa perspectiva, algumas instalações urbanas realizadas entre 2005 e 2008 serão revisitadas na tentativa de estabelecer diálogos com os artistas e assuntos anteriormente investigados na dissertação. Assim, em paralelo à pesquisa teórica, o projeto se propôs a incluir uma dimensão prática, que resultasse em uma nova proposta de intervenção no bairro do Bexiga, ambicionando dialogar com as inúmeras questões de memória coletiva suscitadas naquele território e em especial com a atual luta pelo Parque do Bexiga. ${ }^{1}$

1 O Parque do Bixiga é um projeto de Lei (PL 805/2017) que prevê a criação de uma área verde pública, de característica cultural, no coração da Bela Vista, Bixiga. 
COR 


\section{PARTE 1: COR}

O intuito desse capítulo inicial é estabelecer o quadro teórico de referência da pesquisa, que tem como objeto primordial a investigação sobre a relação entre luz, cor e olho

humano. É importante ressaltar que esse objeto de estudo insere-se dentro do campo das artes performáticas, tendo a relação entre espectador e obra como ponto central. Trata-se de um campo teórico bastante abrangente e por isso o recorte definido detém-se, principalmente, sobre as reflexões teóricas do artista brasileiro Hélio Oiticica em relação à luz e cor e, mais especificamente, sobre o conjunto de textos que resultou no celebre livro "Aspiro Ao Grande Labirinto".

A escolha de utilizar a obra de Oiticica como eixo principal do trabalho deriva da potência de suas reflexões e da forma como elas conectam aspectos essenciais das experiências artísticas que serão analisadas ao longo da dissertação, nas quais a cor ganha uma dimensão importante dentro da relação proposta entre espaço e espectador. É importante ressaltar, no entanto, que não pretendemos abarcar a dimensão total da obra de Oiticica e sim suas contribuições teóricas acerca da sua conceituação de cor-luz, que é o aspecto que se relaciona de maneira mais direta ao escopo da pesquisa.

Em "Aspiro ao grande Labirinto" Oiticica sugere a busca por uma experiência metafísica com cor e espaço, abordando a questão a partir de uma relação temporal que seria estabelecida entre esses elementos e buscando não um espaço racionalizado, mas um espaço temporalizado pela própria experiência e pela cor. Esse entendimento da cor enquanto experiência, como alguma coisa viva, que é impossível de ser totalmente racionalizada, e que acontece a partir de uma vivência temporal, aproxima-se das proposições de Goethe no tratado "Doutrina das Cores", que é, por sua vez, outra referência fundamental na reflexão que se pretende desenvolver a respeito dos conceitos de cor e de luz.

Em suas investigações, o poeta alemão, estabelece alguns parâmetros para o entendimento das cores a partir da observação cuidadosa e detalhada da natureza. Nesse sentido Goethe contesta a teoria Newtoniana que propõe que a luz branca seja a somatória dos espectros de cor encontrados no arco-íris². Ele considera que essa conclusão cientifica está determinada por condições bastante controladas e que a observação da luz na natureza

2 "Depois de interceptar um raio de luz com um prisma, fazendo surgir as cores do espectro, Newton realizou uma operação adicional em que as cores, ao atravessar um segundo prisma, ou uma lente convergente, recompunham a luz branca original. A decomposição da luz branca pelo prisma permitiulhe deduzir que a separação espacial das cores simples é obtida graças ao grau diferente da refração de cada cor revelado ao atravessar corpos transparentes. (...) As aferições dos raios refratados possibilitaram a Newton retirar a noção de cor do âmbito das impressões subjetivas para introduzi-la no caminho das medidas e verificações matemáticas." (PEDROSA, 2014, p.60) 
nos leva a outras percepções. Para Goethe a luz não está somente fora de nós, mas também em nós, e é nessa relação que se forma a nossa percepção das cores.

Goethe acredita que os espectros de cor não constituem a luz solar mas se formam justamente do encontro entre o claro e o escuro, entre a luz e a escuridão. Ele propõe a ideia de um olho vivo, que participaria ativamente do processo de formação das cores, o que significaria que as cores não podem ser consideradas como algo que exista em separado dessa experiência. Assim, Goethe apresenta uma noção de totalidade da experiência, em que as cores surgem da tensão entre luz e escuridão presente no processo dialético da natureza. Para ele a idéia de cor não pode ser dissociada da idéia de luz. De forma similar ao que se observa no texto de Oiticica, podemos identificar em Goethe a busca de um conceito de cor que se estabelece por meio da experiência e que tem no corpo humano um ponto de contato fundamental.

\begin{abstract}
"A natureza oscila com um leve movimento pendular, cria um aqui e um ali, um alto e um baixo, um antes e um depois, aos quais estão condicionados todos os fenômenos, que se manifestam para nós no tempo e no espaço. (...) Sempre os percebemos na medida que em que se unificam ou se separam, animam a existência e promovem alguma forma de vida."
\end{abstract} (GOETHE, 2013, p.62)

Em sua produção artística, ao longo da década 1960, Oiticica desenvolveu diversas experimentações relacionadas à luminosidade das cores, perseguindo um estado puro da cor a partir da criação de diferenças muito suaves de tons, que por fim resultavam em monocromias. 0 artista escreve em seu diário que essas experiências buscavam encontrar o 'sentido da cor', e que para isso ele partia da idéia de 'cor-luz', ou da 'luminosidade anterior da cor', até culminar no que designou como "desenvolvimento nuclear da cor". A noção de "desenvolvimento nuclear" é bastante pertinente ao tratamento que será adotado, ao longo dissertação, em relação ao uso da cor, já que parte da ideia de que existe uma potencialidade inerente à cor a ser revelada. É a partir dessa premissa que a ideia de cor-luz começa a desenvolver-se no e para o espaço e é nesse sentido que a estruturação das obras de Oiticica vai ser problematizada. A cor, entendida enquanto experiência, passaria a pulsar de dentro de seu núcleo e se desenvolver para o espaço.

A ideia de um desenvolvimento estrutural da cor proposta por Oiticica gerou uma série de experimentações escultóricas (bólides) e culminou no que o artista chamou de penetráveis: instalações compostas por diversos materiais que propunham uma experiência de imersão na cor, quando o espectador era convidado a penetrar a estrutura das obras. 
O ponto de partida para os penetráveis é a ideia de uma cor performática no espaço e no tempo. Estes labirintos virtuais sugerem uma vivência temporalizada do espaço em que a cor, enquanto agente estético, afasta-se de qualquer função decorativa. De forma que a estrutura total da obra só pode ser apreendida na experiência de desvendamento desse labirinto, uma vez que é impossível ver as partes simultaneamente. Cor, tempo, estrutura e espaço são entendidos por Oiticica como dimensões da obra, que se relacionam com uma outra dimensão, a 'dimensão infinita'. Esta não seria a possibilidade de a obra se 'dissolver ao infinito', mas se define pelo sentido ilimitado, de não-particularidade que há na relação entre vazio e cheio, desnível de cor, direção espacial e duração temporal.

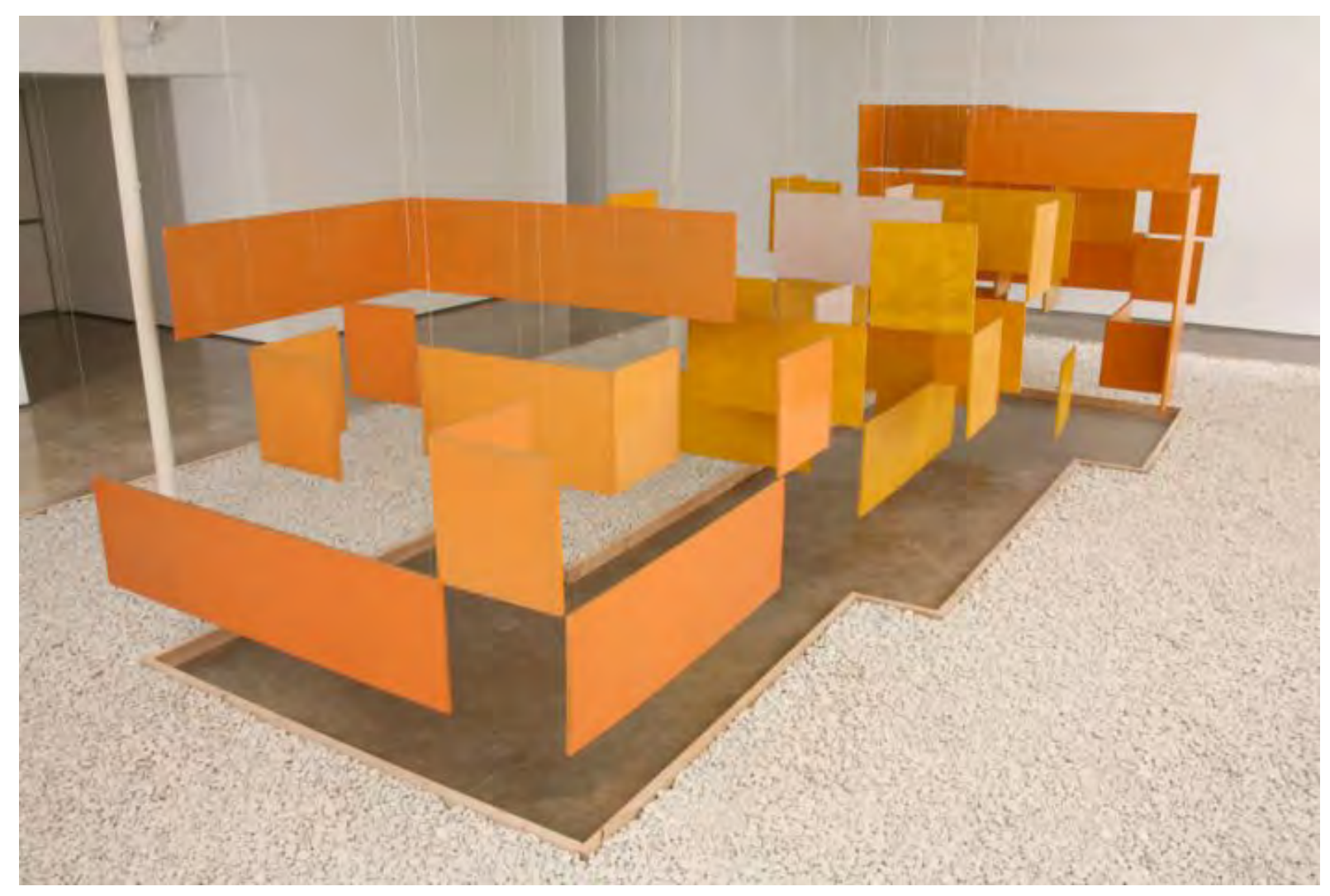

Hélio Oiticica, Grande Núcleo composto por: NC3, NC4 e NC6, 1960.670 x $975 \mathrm{~cm}$ FONTE: http://www.heliooiticica.org.br/english/obras/obras.php?idcategoria=7 
A compreensão de que existe uma cor performática, que pode ser entendida como uma ação e cuja estrutura se constrói na relação com o espaço, é também herdeira das reflexões de Piet Mondrian, cujos escritos sobre a metafísica da cor influenciaram bastante Oiticica. Em um trecho citado por este em seu diário, Mondrian pontua que o futuro indica uma a arte que não se estabelecerá como algo separado de seu entorno, e no qual pintura e escultura não se manifestarão como objetos distintos. Essa não separação, se relaciona com a noção de totalidade da arte que Oiticica perseguirá em sua obra, e que tem um caráter transcendental, quando ocorreria uma fusão entre o sujeito e o objeto.

0 tipo de relação entre sujeito/objeto proposta por Oiticica permite estabelecer uma ponte com outro elemento teórico importante para essa pesquisa, que é a fenomenologia de Merleau-Ponty. Dentro dessa perspectiva, a relação dialética entre o sujeito e o objeto - na experiência - distancia-se de uma noção intelectualista, onde há uma separação entre a sensação, e o que é percebido, e em que as partes estão isoladas. A percepção se daria a partir de um sujeito situado, e o corpo seria compreendido como uma totalidade sistêmica. A ideia da dissolução entre plano e fundo e de uma dimensão relacional da experiência, em que a obra de arte só se dá nessa relação espaço temporal, está pois muito ancorada em Merleau-Ponty. $\mathrm{O}$ autor refuta a lógica dualista e acredita que os objetos não podem ser percebidos de maneira isolada. Para Merleau-Ponty, é justamente na dinâmica relacional que se constituem as partes, e seria impossível atingir-se qualquer olhar totalizante pois o sujeito estaria desde já imbricado na experiência do olhar. De forma que para Oiticica, a relação com o tempo torna-se um dos fatores cruciais na experiência artística que ele está propondo, o que o aproxima da filosofia e das leis de percepção, sobretudo pelo sentido simbólico na relação existencial do homem com o mundo.

\footnotetext{
"A gênese da obra de arte é de tal modo ligada e participada pelo artista, que já não se pode separar matéria de espirito, pois, como frisa Merleau-Ponty, matéria e espírito são dialéticas de um só fenômeno. 0 elemento condutor e criador do artista é a intuição, e, como disse certa vez Klee, 'em última análise a obra de arte é intuição, e a intuição não poderá ser superada.' " (OITICICA, 1986, p.49)
}

\section{Cor Metafísica}

Essa concepção metafisica da obra de arte, e especialmente no que diz respeito a cor, proposta por Oiticica, remete à busca do artista francês Yves Klein que, também inserido no contexto cultural da década de 1960, desenvolveu experiências artísticas ligadas às 
propriedades imateriais da cor. Klein elaborou a ideia do que chamou de "sensibilidade pictórica" partindo de propostas muito radicais de experimentação, nas quais buscava extrapolar a materialidade física da cor. Partindo de uma exploração da luminosidade da cor, suas proposições artísticas se desdobraram em happenings e performances em que forma e estrutura se definiam na relação estabelecida, a partir do corpo, entre a cor e o tempo. Existe também em sua obra a busca por uma experiência perceptiva que seja capaz de transcender a vivência puramente material da cor. Para Klein a Natureza transcende a fisicalidade e a materialidade do que podemos apreender com os nossos cinco sentidos.

Klein partiu de estudos e pinturas monocromáticas até chegar em um tom de azul que denominou azul Klein, e começou a investigar as possíveis diferenças pictóricas que haveriam entre esses monocromos azuis elaborando a ideia de uma sensibilidade pictórica imaterial. As obras desse período - situadas em meados da década de 1950 - ficaram posteriormente conhecidas como "período azul". Segundo o artista essa fase foi uma iniciação tanto para ele mesmo quanto para o público e depois disso ele estava pronto para embarcar na corrida pelo azul imaterial. Este azul imaterial seria a realidade invisível da pintura, ou a realidade de uma totalidade pictórica.

Aos monocromos da fase azul sucederam outras experiências que buscavam transcender a materialidade das pinturas; como na exposição de 1958 ocorrida na galeria Iris Clert, em Paris, e que ficou conhecida como a exposição do "vazio" (void). Para essa exposição o artista criou toda uma atmosfera no exterior da galeria com o intuito de que o publico entrasse em contato com a materialidade da cor azul. Ele alterou a orientação da entrada da galeria e cobriu - até a altura do olho - as janelas que davam para rua e as portas com tecido azul. Antes que o público fosse convidado a entrar na galeria foi oferecido um coquetel azul de gin, Cointreau e azul de metileno. 0 artista havia ainda conseguido autorização para iluminar em azul o obelisco, próximo ao evento, da Praça de La Concorde; o que acabou não acontecendo porque a polícia cancelou de última hora a permissão. Após experimentarem se relacionar com a cor azul, a partir desses elementos materiais cuidadosamente escolhidos pelo artista, o público era convidado a entrar na galeria toda esvaziada de objetos e se deparava com um espaço inteiramente vazio, com as paredes inteiramente brancas, imantadas pelo que o artista chamou de sensibilidade pictórica imaterial. Dessa forma o azul visível e tangível estaria no exterior da galeria, enquanto que no interior estaria a desmaterialização do azul.

Nas palavras de Klein: 
"Esse estado pictórico, invisível no espaço da galeria, deveria ser sob todos os aspectos a melhor definição de pintura até agora dada, quero dizer: radiação. Invisível e intangível, essa imaterialização da pintura deveria atuar, no caso de o processo criativo ser bem sucedido, sobre os veículos e corpos sensíveis dos visitantes da exposição de maneira mais efetiva do que pinturas visíveis, representações comuns, sendo elas figurativas, não figurativas, ou até monocromáticas." (KLEIN in RIOUT, 2010, p. 62) 3

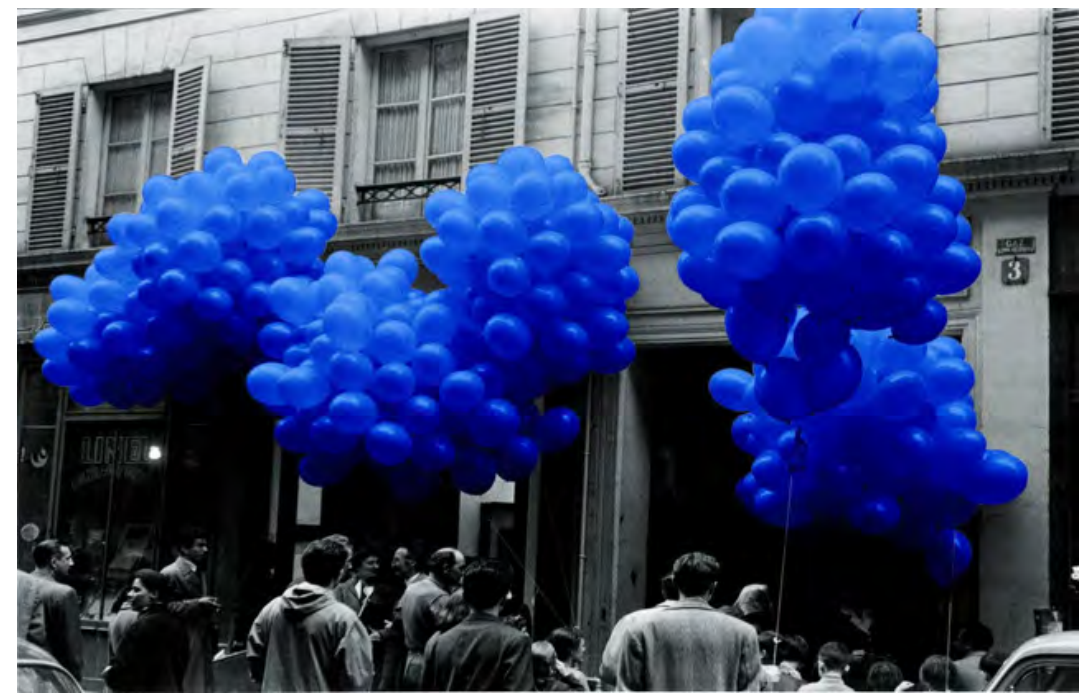

Yves Klein, Aerostatic Sculpture, 1957.

FONTE: https://blog.artsper.com/en/a-closer-look/10-things-to-know-about-yves-klein/

O ambiente da década de sessenta, no contexto das artes, se construiu a partir de vários elementos, mas, no caso de Klein e Oiticica, os estudos sobre fenomenologia que derivaram de Husserl parecem ter favorecido um campo de pesquisa onde a experiência relacional tornou-se central para os trabalhos. Além disso, ambos os artistas, ao desenvolverem suas pesquisas com a cor, partiram do estudo sobre a radiação da cor e sua luminosidade. Desta forma parece ser possível aproximar a noção de "sensibilidade pictórica" perseguida por Klein e o que Oiticica irá chamar de "dimensão infinita do trabalho". Ambos aspiram encontrar na arte, e, especialmente, na cor, uma dimensão cósmica para suas obras.

3 "This pictorial state, invisible within the gallery space, should in every aspect be the best definition of painting yet given, that is to say: radiance. Invisible and intangible, this immaterialization of the painting should act, if the creative process is successful, upon the vehicles or sensible bodies of visitors to the exhibition much more effectively than visible, ordinary representative paintings, whether they be figurative, nonfigurative, or even monochromes." (Tradução livre da autora). 
"O desenvolvimento nuclear antes de ser a dinamização da cor é a sua duração no espaço e no tempo. É a volta ao núcleo da cor, que começa na procura de sua luminosidade intrínseca, virtual, interior, até o seu movimento do mais estático para a duração. (...) Dai ao se desenvolver tudo para o espaço, a cor começou a tomar forma de um desenvolvimento a que chamo nuclear; um desenvolvimento que seria como se a cor pulsasse do seu estado estático para a duração; como se ela pulsasse de dentro do seu núcleo e se desenvolvesse. (...) de uma busca dessa dimensão infinita da cor (...) procura também, e principalmente, se firmar no sentido puramente transcendental de si mesmo." (OITICICA, 1986, p.40)

Oiticica busca enquanto artista, assim como Ives Klein, religar sua relação com o espaço em um sentido universal, não particular, buscando o transcendental. É na relação entre as partes que se dá a realização da obra, ou seja, trata-se de uma relação espaço-temporal. Existe em ambos uma aspiração ao sublime e o próprio Oiticica descreve seu diário como algo menos racional do que espiritual. 0 sentido existencial da pesquisa desses artistas transborda a noção de obra de arte enquanto objeto e imprime uma visão da obra de arte a partir de sua experiência no espaço e no cosmos.

\footnotetext{
"Uma grande ordem não seria forçosamente racional, mas sim que possua tal significado a cor que poderia dizer que é cósmica ou sublime no seu sentido. Esse caráter da cor nasce de uma necessidade existencial, que, por ser existencial,supera ouse elevaacimadocotidiano,para emprestaràvidaexistencial um clímax, um sopro de Vida. (...) A cor é uma necessidade religiosa, como quem fizesse preces dialogasse aqui com a cor e se estruturasse.(...)." (OITICICA, 1986, p.30)
}

Não é possível abordar de nenhuma forma a metafisica da cor ou da arte sem ao menos citar o pintor russo Wassily Kandinsky que publicou em 1911 o livro "O espiritual na Arte". Nesse tratado Kandinsky propõe uma aproximação da pintura com a música, relacionando os elementos paradigmáticos da pintura - a cor e a forma - com os elementos paradigmáticos da musica. Dessa forma Kandinsky busca encontrar uma sonoridade da cor, sendo esse elemento musical, na opinião de Oiticica: "o verdadeiro elemento de não -objetivação da sua pintura, e por isso mesmo toma um sentido de absoluta importância, altamente transcendental, eixo mesmo de sua obra" (OITICICA, 1986, p.19) 
O texto de Kandinsky profetiza uma tendência da pintura rumo à composição pura e a sua própria desmaterialização, e atesta uma mudança na arte rumo ao espiritual. Ele convida o espectador para uma arte que se apresente para além de qualquer habilidade técnica do artista e que não esteja presa ao seu suporte; mas cujo conteúdo, sua essência, possa tocar a alma de seus espectadores. Kandinsky recupera as considerações de Goethe sobre os caminhos futuros da pintura e que sugerem a criação de uma base fundamental para este campo. A partir das colocações de Goethe, o artista aponta para a necessidade de desenvolvimento dos meios que são próprios à pintura (cor e forma) para que seja possível, através disso, atingir-se o sentido abstrato do termo arte e a realização de uma composição pictórica pura. Isso se daria menos pelas leis da física e mais pelas leis espirituais, que ele chamou de "Necessidade Interior".

\begin{abstract}
"Apesar, ou melhor, em virtude do isolamento da Arte, nunca as artes estiveram mais próximas umas das outras do que nestes últimos tempos, neste momento decisivo da Mudança de Rumo Espiritual. A cor provoca, portanto, uma vibração psíquica. E seu efeito físico superficial é apenas, em suma, o caminho que lhe serve para atingir a alma." (KANDINSKY, 1990,p.64)
\end{abstract}

\title{
Programa Ambiental
}

Oiticica trata da questão perceptiva da cor como um conjunto de relações que se estabelecem entre espectador e obra, em que nada está isolado, transbordando o campo das artes visuais e problematizando a cor em sua relação temporal com o espaço. É justamente sua investigação a respeito de uma arte relacional ao longo da década de 1960 - que como visto acima foi muito influenciada pelo filosofia fenomenológica - que conduz Oiticica ao que ele chamou de Programa Ambiental.

Em 1966 o artista desenvolve uma série de bólides que se distanciam dos estudos com cor precedentes, chamados de "transobjetos", em que ele incorporava materiais cotidianos (por exemplo uma cuba de vidro) em sua pesquisa escultórica sobre a estruturação da cor. Esses bólides caracterizavam-se pelo fato de não trazerem qualquer alteração na estrutura física do objeto apropriado. Mesmo que a funcionalidade social desses objetos fosse alterada, sua estrutura física era mantida intacta. 0 'bólide-lata', por exemplo, uma lata de fogo com estopa embebida em óleo, se torna uma referência dessa busca por estender a arte não somente para fora das paredes institucionais, mas para uma espécie de sensibilização da experiência cotidiana. A lata de fogo não se refere mais tão somente "aquela" lata de fogo, mas a todas as latas de fogo que se encontram na paisagem. 
“(...)inclusive pretendo estender o sentido de 'apropriação' às coisas do mundo com que deparo nas ruas, terrenos baldios, campos, o mundo ambiente, enfim - coisas que não seriam transportáveis, mas para as quais eu chamaria o público à participação (...) Museu é o mundo; é a experiência cotidiana (...). A experiência da lata-fogo a que me referi está em toda parte servindo de sinal luminoso para a noite - é a obra que isolei na anonimidade da sua origem - existe aí como que uma 'aproximação geral': quem viu a lata-fogo isolada como uma obra não poderá deixar de lembrar que é uma 'obra' ao ver, na calada da noite, as outras espalhadas como que sinais cósmicos, simbólicos, pela cidade: juro de mãos postas que nada existe de mais emocionante do que essas latas sós, iluminando a noite (o fogo que nunca apaga)." (OITICICA, 1986, pag. 79 e 80)

A problematização da experiência tonal e de sua estruturação no espaço se desloca para o contexto social - no caso de Oiticica, o brasileiro - em que estas experiências estão inseridas. Com isso, as escolhas estéticas do artista passam a incorporar diferentes signos dessa paisagem social. E será a partir dos elementos que ele encontra dispostos 'no mundo' e nas experiências cotidianas que Oiticica estrutura sua pesquisa. As questões levantadas em seu Programa Ambiental são muito pertinentes para a análise das experiências artísticas abordadas ao longo da presente dissertação. Um dos critérios adotados para a seleção dos artistas foi o fato de estarem inseridos no contexto brasileiro e de isso ser determinante nas suas escolhas estéticas.

\section{Califórnia}

Desde a fase de elaboração desse projeto de pesquisa existia a vontade de estudar a obra de dois artistas californianos: James Turrel e Robert Irwin. Os dois norte-americanos, também inseridos no cenário cultural da década de sessenta e muito influenciados pelos estudos fenomenológicos, desenvolvem obras que serão classificadas como "fenomenológicas". Turrel e Irwin partem do movimento norte americano de arte Minimalista porém acabam extrapolando-a e focando na questão perceptiva, que se torna eixo central de suas obras. É importante ressaltar que o contexto social norte-americano levou a um desenvolvimento de seus trabalhos muito distinto do que ocorreu com Oiticica. Mas, pelo fato de compartilharem um entendimento perceptivo das cores e da luz que os aproxima de Oiticica, considero importante situar brevemente a trajetória desses artistas e, em especial a de James Turrel, que busca dialogar com as forças da natureza por meio de sua obra. 
Anna Barros, em "A arte da percepção"-livro que resulta de sua tese de doutoradoaborda as obras de Turrel, e propõe uma relação entre a arte fenomenológica e o minimalismo norte-americano:

"A arte fenomenológica vem da necessidade profunda de renovação da compreensão do que é realidade e de como apreendê-la, visando ao surgimento de uma conscientização sobre a qual seja o nível em que nos relacionamos com a natureza das coisas. Tem em comum com o Minimalismo essa necessidade de ir buscar, na experimentação direta do fenômeno, a gênese do trabalho e também o emprego de elementos mínimos para atualizá-lo, mas aqui beirando total imaterialidade, pois tem de ser composta pela percepção e não ser sobre percepção." (BARROS, 1999, p.21)

A trajetória de Robert Irwin, assim como a de Oiticica, tem como ponto de partida a pintura e é a partir da investigação do comportamento das cores e da forma com a luz pode ser irradiada através de jogos perceptivos, que sua obra ganha progressivamente uma dimensão ambiental. Irwin parte do estudo da relação entre figura e fundo, e da tensão entre essas dimensões, para buscar, de forma declarada, trazer à tona as questões de cunho filosófico que emergem desse tema; ou seja, problematizando a maneira como nós nos relacionamos com o nosso meio. Irwin acredita que é na relação espaço temporal, partindo do movimento, que se dá a consciência perceptiva. 0 artista está vivo e ainda em atividade, sua obra é extremamente vasta e se desdobrou de inúmeras formas. Embora não seja possível discorrer aqui sobre a totalidade de sua produção, algumas de suas reflexões podem ser bastante oportunas para o sentido de experiência com o espaço que essa investigação almeja. É bastante interessante, por exemplo, a maneira como ele articula as noções de ser no tempo, espaço e presença, como aspectos primários da experiência.

“[E]las [as pinturas] agora estão se dirigindo à raiz da questão que, tanto na filosofia como na física, não são, de maneira alguma, sobre o jogo de ideias ou incidentes. São sobre a relação básica entre três ou quatro aspectos primários da experiência no mundo: ser-no-tempo, por exemplo, espaço e presença. Quando você deixa de atribuir-lhes uma leitura literária ou articulada (o tipo de leitura que você daria a uma pintura Renascentista), e em lugar disto olha para elas perceptualmente, você realiza que seus olhos terminam suspensos em pleno ar, no meio do espaço ou no meio da distância: o tempo e o espaço parecem se fundir na continuidade da sua presença." (IRWIN in BARROS, 1999, p.31) 
0 artista James Turrell não tem como ponto de partida a pintura, mas sim a gravura, para sua investigação. Turrell se ocupa inicialmente da materialidade da luz. A ele interessa dar um tratamento espacial ao fenômeno luz, dotando-o de espessura e densidade. A cor também vai assumindo importância a medida em que ele começa a criar espaços de imersão onde cor e luz provocam o sistema visual do espectador a funcionar de maneira diferente da usual. Em paralelo, o elemento tempo adquire uma enorme importância no trabalho de Turrel, que propõe ao publico novas experiências temporais.

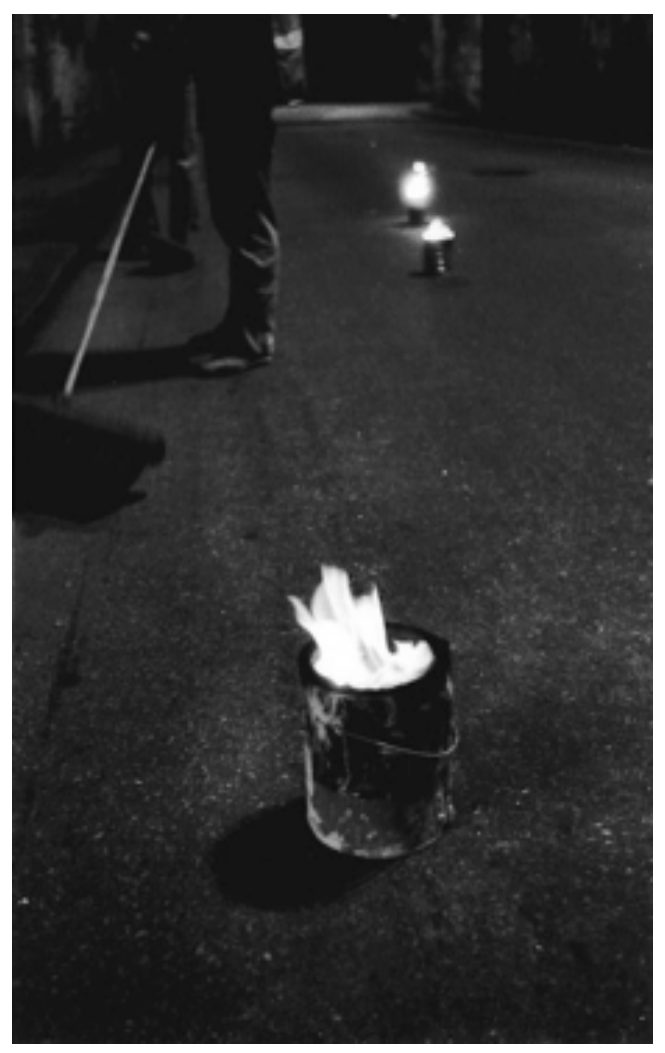

Hélio Oiticica, Bólide de fogo,1966.

Foto Cesar Oiticica Filho (Cortesia Projeto HO)

FONTE: https://www.vitruvius.com.br/revistas/read/arquitextos/18.208/6720 
É possível perceber que as questões que movem o trabalho desses dois artistas são muito próximas das que encontramos presentes na obra de Hélio Oiticica, embora as soluções encontradas por eles se distanciem bastante. Não teríamos como saber de que forma o trabalho de Hélio se desenvolveria se ainda estivesse vivo, ao longo dos anos e com os novos aparatos tecnológicos disponíveis. 0 fato é que ambos os artistas californianos ainda estão vivos e incorporaram em suas pesquisas o que existe de mais tecnológico e sofisticado.

Por exemplo, uma das obras a que James Turrell mais se dedicou ao longo de sua carreira é o Roden Crater. Trata-se de um projeto gigantesco, elaborado ao longo de mais de 30 anos, em que propôs uma ocupação dentro de uma extinta cratera vulcânica no Arizona. Neste trabalho todos os elementos estéticos estão intimamente ligados à tentativa de estabelecer uma relação com os elementos naturais que compõe aquela paisagem, em que o céu e os astros assumem grande protagonismo; uma união entre o céu e a terra.

Outros trabalhos do artista trazem esse mesmo desejo de reconectar seu espectador com o espaço cósmico. Ao redor de diversos cantos do mundo, ele propôs instalações que criam aberturas para a observação do céu em meio a estímulos de luz artificial. A luz-cor transforma-se em pura manifestação, enquanto as aberturas criam molduras de observação do céu propondo um tempo novo de experiência para o público, no qual a conexão com a entidade céu é determinante. Essa conexão que o artista busca com as forças da natureza parece se conectar com a mesma busca por uma arte de caráter transcendental apontada nas obras de Oiticica, Klein e Kandinsky.

No entanto, apesar de esses artistas Californianos trazerem questões pertinentes à essa pesquisa no que se refere à percepção visual da luz, a forma e o contexto em que essas obras se realizaram distancia-se não só do contexto brasileiro, mas da perspectiva da dissertação, que tenta se aproximar de uma arte preocupada em problematizar o espaço urbano a partir das contradições e das questões politicas inerentes à esses espaços. De forma que os próximos capítulos vão tentar um aprofundamento da noção de arte urbana; mas tendo em conta as contribuições teóricas desse primeiro capitulo no que se refere a questão da performatividade da cor e da luz. 
 \\ CIDADE

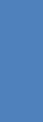

CIDADE

(2)

(2)

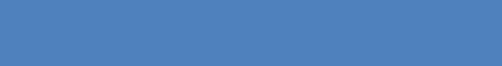




\section{PARTE 2: CIDADE}

A escolha dos objetos de estudo dessa pesquisa parte do entendimento de que a arte urbana tem o potencial de requalificar a experiência da vida social na cidade. E tendo em vista o eixo central da investigação - a relação estabelecida entre o olho humano, luz e espaço - essa parte do texto tentará estabelecer um pano de fundo para as reflexões que se seguirão adiante, com a finalidade de apresentar o interesse pelo campo do cotidiano e do espaço urbano a partir da obra de dois autores que foram referências essenciais para o processo de investigação até aqui: Henri Lefebvre, em especial pela obra "O Cotidiano no Mundo Moderno" (1968) e Vera Pallamin com “Arte, Cultura e Cidade" (2015). Ambos autores propõe reflexões sobre as maneiras com que propostas de arte urbana podem operar nas esferas do cotidiano.

No livro citado, Lefebvre propõe uma noção de cotidianidade que parte de um mapeamento bastante pertinente para se pensar as esferas que compõem o cotidiano até os dias de hoje. Ele entende a cotidianidade como um campo com alto potencial de transformação social e, nesse contexto, situa a cidade como o lugar possível para os embates e mudanças acontecerem. Já Pallamin levanta questões sobre a natureza de práticas artísticas que operam no espaço urbano a partir das concepções de estética formuladas por Jacques Rancière, em especial sobre a noção de dissenso ${ }^{4}$, e que dialogam com o entendimento potencial que Lefebvre faz do espaço urbano.

A ideia aqui é buscar nesse aparato teórico uma chave de leitura para as performances de Eleonora Fabião e Guilherme Bonfanti. Existe uma vitalidade na maneira como as performances de Fabião - e suas reflexões teóricas - se relacionam com o cotidiano que é muito enriquecedora para essa pesquisa e que partem do entendimento do artista performer como alguém que busca abrir fissuras dentro do espaço normatizado pelo cotidiano e na tessitura da experiência urbana. Da mesma forma que algumas das operações propostas por Bonfanti no espetáculo "Bom Retiro 985m" tem uma enorme capacidade transformar a relação dos espectadores com a cidade.

\section{Cotidiano e Cidade}

4 "Em sentido estrito, a política não tem um lugar próprio ou sujeitos pré-definidos. É trabalho de subjetivação realizados em nome da igualdade, que desafiam a ordem em vigor da ação, percepção e pensamento. Ela só existe em atos intermitentes de implementação, sem obedecerem a uma lei geral, mas tendo como operador comum o dissenso. Esta noção diz respeito a um processo político que cria uma fissura na ordem sensível, confrontando a estrutura dada e suas repartições, redesenhando campos de pertencimento." (PALLAMIN, 2015, p.25) 
De inicio é importante ressaltar que a noção de cotidiano proposta por Lefebvre em 1968 - e que vai servir de base para reflexões desenvolvidas no âmbito dessa pesquisa - tem como objeto de análise a sociedade moderna francesa. Dada a devida distância que nos separa do texto, é importante considerar que algumas questões apontadas por Lefebvre colocam-se de forma ainda mais complexa em nossa sociedade dita pós-moderna, como, por exemplo, a consolidação da internet e a velocidade com que a informação e os meios de produção circulam em um mundo globalizado. No entanto, parece-me que nessa obra o autor formula algumas questões essenciais para a compreensão da nossa sociedade atual - principalmente sobre o caráter estratégico que está atrelado ao cotidiano - estabelecendo bases sólidas para compreender estruturas que operam e formatam a sociedade até hoje.

Para Lefebvre o cotidiano é entendido como o campo onde se produz a existência social dos seres humanos. 0 autor considera que é através do cotidiano que se dá a normatização da sociedade e por onde são instaurados padrões de normalidade e valores normativos. Segundo ele não é possível entender a cotidianidade no mundo moderno como um sistema isolado que opere sobre a vida social. Lefebvre defende a ideia de subsistemas (cientificismo, positivismo, funcionalismo, etc.) que operam articulados na construção do cotidiano, justificados por sistemas de valores (moral, estética, ética) e travestidos como não ideológicos.

\footnotetext{
"A vida cotidiana se organiza como resultado de uma ação combinada, semiplanejada (na França). Cada vez mais clara e fortemente as atividades chamadas superiores (formas, modelos, conhecimentos aplicados) não apenas se situam em relação ao cotidiano, mas ainda o tomam por objeto. Ele se torna o plano sobre o qual se projetam os claros e os escuros, os vazios e os cheios. As forças e as fraquezas dessa sociedade. Forças políticas e formas sociais convergem nesta orientação: consolidar o cotidiano, estrutura-lo, torná-lo funcional." (LEFEBVRE, 1968, p.73)
}

Diante de uma complexa teia de subsistemas que compõe a cotidianidade, e justamente por conta dela, o cotidiano é entendido como cenário possível para que os pontos de inflexão da história se deem. E nesse contexto Lefebvre situa a cidade como o lugar potencial dos encontros, onde desvios e imprevistos podem acontecer; um lugar de invenção. 0 conceito de urbano tem para Lefebvre um caráter quase utópico, assumindo uma resistência efetiva e virtual contra a cotidianidade, a partir da própria cotidianidade. 
E é a partir da perspectiva do potencial inventivo do espaço urbano que se pretende estabelecer diálogo com ideias de Vera Pallamin e guiar o olhar até os objetos de estudo dessa dissertação.

"A exploração das situações cotidianas supõe uma capacidade de intervenção, uma possibilidade de mudança (de reorganização) no cotidiano, que não são do domínio de uma instituição racionalizadora ou planificadora. (...) Enquanto práxis na escala global da sociedade, ela faz parte da revolução cultural baseada no fim do terrorismo, ou, pelo menos, na possibilidade de intervenções contraterroristas." (LEFEBVRE, 1968, p.199)

Segundo a Pallamin o regime estético é proposto por Rancière "como uma articulação entre as maneiras de fazer, suas formas de visibilidade e o modo de pensabilidade de suas relações". Para o autor, o sensível é situado como um campo primeiro sobre o qual as ações se dão, sendo um domínio do estético e do político simultaneamente. Desta forma, Rancière situa o regime estético como uma dinâmica que opera sob duas lógicas distintas: a separação entre arte e vida (a função da arte é não ter função), e a da indiferenciação entre arte e vida (a experiência estética tende a incorporar-se àquela comum). Assim a partir dessa tensão se estabeleceria a dificuldade de analisarmos ações artísticas no presente. A autora demonstra como para Rancière o ato estético é indissociável do ato político e que surge desse atrito apresentado na dinâmica da experiência sensível. Rancière defende que a ideia de democracia estaria também abarcada por essa tensão - ou processo dialético - e a noção de dissenso seria fundamental para a reflexão sobre as questões estéticas e sobre a potencia da arte.

De forma que é via dissenso que se apresentariam as possibilidades de ruptura de um estado das coisas onde as relações de dominação estão naturalizadas e cristalizadas. Nesse sentido a experiência urbana se tornaria mais que um lugar de encontro, um lugar de conflito. A arte urbana é destacada por Pallamin como uma prática crítica que inclui entre seus propósitos estéticos o desafio a certos códigos de representação dominantes, a redefinição de valores e a abertura de outras possibilidades de apropriação e usufruto dos espaços urbanos físicos e simbólicos. As proposições de Lefebvre também já pontuavam, em 1968, pistas de um campo possível de atuação no cotidiano com visas a uma reprogramação social; que ele apontava como uma possível revolução cultural a partir de ações 'contra-terroristas'. A análise da obras que seguirão nos próximos capítulos parte de um compreensão dessas ações artísticas pela chave do dissenso, no sentido de que elas 
operam desarmando as estruturas de programação e abrindo outras possibilidades de entendimento do cotidiano.

\begin{abstract}
"Pelo contrário, potencializada pela ideia de tornar a cidade disponível para todos os grupos, essa prática crítica inclui entre seus propósitos estéticos o desafio a certos códigos de representação dominantes, a introdução de novas falas e a redefinição de valores como abertura de outras possibilidades de apropriação e usufruto dos espaços urbanos físicos e simbólicos."
\end{abstract} (PALLAMIN, 2015, p.145)

\title{
2.1 A FISIOLOGIA DA LUZ NAS PERFORMANCES DE ELEONORA FABIÃO.
}

O intuito dessa seção é propor uma reflexão sobre algumas ações da artista performer carioca Eleonora Fabião tendo em vista a maneira como estas relacionam cor, luz e corpo. Desde de 2008 Fabião vem realizando performances pelas ruas de diferentes cidades, nas quais ela se utiliza de múltiplas estratégias para se conectar (ou desconectar), com esses espaços. Sua obra é extremamente vasta, e como ela mesma disse em uma conversa, parafraseando Hélio Oiticica, "tudo que existe no mundo pode ser material de meu trabalho". Algumas vezes a chave principal de conexão com suas performances está ligada à dimensão textual e à palavra, enquanto em outras o foco se dá a partir de questões de ordem pictórica e ligadas a uma dimensão sensorial do espaço. Nesse sentido a análise das obras escolhidas para esse texto partirá de uma abordagem fenomenológica baseada na ideia de que a luz se estabelece numa relação de subjetividade entre o olho e o espaço; o olho é entendido como um órgão ativo que provoca no cérebro variadas sensações, numa relação sempre dinâmica. Uma das premissas dessa investigação é a percepção de que cor e luz são fenômenos visuais complexos que ocorrem a partir da relação do olho humano com diferentes padrões vibratórios, de forma que ambas são experiências subjetivas e estão ligadas ao aparelho visual de cada individuo, o que nos leva a entende-las como expressões de um mesmo processo e, portanto, podemos dizer que cor é luz e luz é cor.

Quando nos debruçamos sobre o conjunto de ações que Fabião vem realizando desde 2008, é possível perceber que as questões de cor e luz são de fundamental importância para suas performances e vários de seus trabalhos relacionam corpo e espaço através do uso de padrões cromáticos. A partir desse amplo conjunto de trabalhos, minha opção foi percorrer de maneira sucinta um histórico de performances que se relacionam com cor 
e luz e em seguida aprofundar a análise de três ações especificas, que aconteceram entre 2015 e 2016, e utilizaram a luz elétrica além de outros materiais que sensibilizam a visão humana, trazendo a tona questões perceptivas da luz como pontos cruciais dos trabalhos. As ações escolhidas são: "No meio da noite tinha um arco-íris" (2015), "Série coisas que precisam ser feitas" (2016) e "Azul, azul, azul e azul” (2016).

Para realizar essa investigação meu ponto de partida serão os textos que fazem parte de seu livro "Ações" (Fabião, 2015) além de outros textos publicados pela artista em revistas e publicações de arte. Além disso, tive o privilegio de conversar pessoalmente com Fabião sobre a pesquisa, o que foi uma grande oportunidade para o desenvolvimento de algumas das ideias presentes nesse texto. Para o aprofundamento teórico nas questões sobre cor e luz a ideia é estabelecer, nesse primeiro momento, diálogo com dois autores: Goethe, referencia preliminar e essencial para o desenvolvimento da pesquisa; e o físico Arthur Zajong, que desde meados de 1970, tem uma pesquisa filosófica e histórica sobre percepção da luz. Zajong, em seu livro "Catching the Light" (1993) propõe uma genealogia que trata deste tema desde a antiguidade mais remota, passando pelos desdobramentos da física moderna, até se deparar com concepções e dilemas contemporâneos acerca da luz.

Outro autor que merece ser destacado é o já citado Maurice Merleau-Ponty, pois a leitura de alguns textos seus foi essencial para os desdobramentos dessa pesquisa. As ideias que compõe esse capitulo partem de algumas das questões levantadas por sua fenomenologia e já apresentadas na primeira parte. De fato, são norteadoras da noção de espaço a ser aqui elaborada, ou melhor, de uma concepção de luz que esta muito imbricada pelas relações espaciais. 0 autor propõe a dissolução do dualismo clássico entre o sujeito e o objeto, a parte e o todo, a figura e o fundo; de maneira que as coisas estão sempre colocadas umas frente às outras em uma dinâmica relacional. Ou seja tanto o sujeito quanto o espaço resultam dessa articulação, e as partes não podem ser compreendidas isoladamente.

De toda maneira, por enquanto, o foco da investigação se concentrará nas questões especificas da luz, e para conceituar o espaço partiremos do próprio entendimento de Eleonora Fabião:

\footnotetext{
"Não entendo a rua como um suporte para as ações que realizo, mas como um campo denso, ou ainda, um cosmos mesmo. A escala é humana mas a extensão é cósmica. Para mim a rua não é um lugar a ser ocupado, mas uma zona altamente carregada, um campo de forças múltiplas e muitas vezes conflitivas, a se mover com. Na rua move-se com a rua, move-se a rua e se é movido por ela. Nesse turbilhão, as matérias não são ocupantes
} 
inertes, são parte das correntezas sociopolíticas e histórico-afetivas que atravessam aquele espaço (trans-temporal) que elas mesmas (todas as matérias humanas e não-humanas) formam em suas metamorfoses contínuas." 5

Dentro dessa perspectiva o espaço é proposto como uma instância ativa no processo de formação social e individual, e pode ser entendido como um campo de articulação entre diversas forças. Parece haver uma aproximação entre a visão de Fabião e a dissolução proposta por Merleau-Ponty - onde as partes só podem ser compreendidas nessa articulação - e portanto há uma compreensão sistêmica do todo. De toda forma trabalharemos com a hipótese de que há, na noção de espaço proposta pela artista, uma dimensão metafisica que se aproxima das proposições levantadas por Oiticica, ligadas ao que o artista chamou de dimensão infinita do trabalho e ao caráter relacional imbricado em sua concepção de arte.

As performances de Fabião propõe um tipo de experiência muito sensível do espaço, adotando-o como um complexo sistema de coisas materiais e imateriais - postas em relação sempre dinâmica - carregado de conteúdos históricos, políticos e físicos. A artista se refere às suas ações como programas. Um programa, segundo ela, é uma 'ação metodicamente calculada e conceitualmente polida', que se aproxima do improvisacional exclusivamente na medida em que não é previamente ensaiada. Assim performar programas seria fundamentalmente diferente de lançar-se em jogos improvisacionais (FABIÃO, 2008, p.237).

\section{Histórico e genealogia}

Como escolha metodológica optou-se por seguir uma ordem cronológica para a apresentação dos trabalhos selecionados. E, a partir do entendimento de que cor e luz estão imbricados de maneira inseparável, foram incluídos nesse recorte alguns programas anteriores às ações selecionadas para a pesquisa por já trazerem experiências de luz muito interessantes para investigação.

A primeira é "Quase nada, sempre tudo", realizada entre 2012 e 2013 na Praça Tiradentes, na cidade do Rio de Janeiro: “1- Quase nada, sempre tudo \#1: 25 tijolos: À luz do dia, numa praça. Por horas seguidas fazer e desfazer composições com 25 tijolos. 2- Quase nada, sempre tudo \#2: carvão: À luz do dia, numa praça. Por horas seguidas fazer e desfazer

5 http://www.premiopipa.com/2018/03/conversa-com-eleonora-fabiao-por-luiz-camillo-osorio/) 
composições com pedaços de carvão. 3- Quase nada, sempre tudo \#3:9 lençóis brancos." (FABIÃO, 2015, p.193 até 205)

E outro programa realizado em 2013, que é: "mancha preta", "mancha vermelha" e "mancha branca": onde a artista ensacava todo o seu corpo com sacos plásticos de uma determinada cor (preto, branco e vermelho), e ação era: Caminhar ensacada pela cidade. É preciso apontar, desde já, que qualquer descrição ou reflexão de trabalhos que propõe experiências dessa natureza estará sempre muito aquém da experiência em si; porém esse é um dilema inconciliável para os estudos de performance e luz. Na oportunidade que tive de conversar pessoalmente com Fabião, quando falávamos sobre as questões de cor e luz, ela destacou a paleta escolhida para esses trabalhos:

\begin{abstract}
"Repara que as manchas também são: branco, preto e vermelho. E você vai encontrar em outros, se você olhar com jeito, você vai ver: branco, preto e vermelho. Essa é uma paleta que depois eu vim a descobrir que tem várias culturas que trabalham com essa paleta, e as significações são inúmeras, em geral estão associadas a material/ imaterial, espiritual ou mental; ou mental, espiritual e material." (FABIÃO, entrevista 26/02/2018)
\end{abstract}

A cor é essencial para esses programas e se coloca como um elemento fundamental, constitutivo do trabalho, embora cada um deles explore a questão de maneira singular a partir do material escolhido. Fica evidente, pelo relato da artista, que essa escolha não é gratuita, pelo contrário. Nesse sentido as cores escolhidas (preto, branco e vermelho) representam cores puras, elementares, e que em algumas culturas representam forças da natureza. Como, por exemplo, o branco e o preto que de certa maneira representam a dicotomia primordial da vida: o yin e o yang, a oposição entre luz e sombra. 0 vermelho também pode ser relacionado à essência da vida através do sangue e também do sol. Tanto na Umbanda quanto no Candomblé essas três cores representam energias de criação da natureza, como por exemplo Oxalá (branco) e Exu (preto e vermelho).

Diante dessa relação dinâmica de oposição entre luz e sombra, é inevitável trazer ao debate as reflexões de Goethe sobre o tema. Como já foi abordado na primeira parte, para Goethe os espectros se formam justamente do encontro entre o claro e o escuro, da tensão entre a luz e a escuridão. Sendo o azul uma derivação do preto, o amarelo uma derivação do branco, e o vermelho sendo a mediação entre esses dois polos, há um estado potencial que ambas as cores podem atingir. Nas palavras de Goethe: 
"Na luz surge para nós, em primeiro lugar, uma cor que chamamos amarelo, e uma outra, na escuridão, que designamos azul." (...) "A oxidação do aço, que vai do amarelo ao azul, passando pelo vermelho, demonstra claramente esse caminho constantemente percorrido.(...).De tudo isso parece resultar que existe na natureza um abismo entre azul e amarelo, que pode ser atomisticamente suprimido e vinculado ao verde por entrecruzamento e mistura, embora a verdadeira mediação de amarelo e azul só ocorra através do vermelho." (GOETHE, 2013, p. 73, 130 e 131)

Em “Quase Nada, Sempre tudo" (2012/2013) existe uma proposta muito clara e concreta que é a exploração dos três materiais escolhidos: tijolos, carvão e lençóis brancos. Se dirigirmos nossa observação para o comportamento desses três materiais na relação com a incidência da luz natural, sem dúvida, vamos perceber fenômenos interessantes. Desses três materiais, no embate com a cidade, a qualidade cromática dos tijolos talvez seja a que se revele de maneira mais discreta. Por outro lado, os casos do carvão ou do lençol branco são bem mais evidentes. 0 carvão é a maior representação da cor preta no mundo natural, e por suas características físicas (opacidade) absorve quase totalmente a luz. Em contrapartida o lençol branco é uma fonte quase primordial de rebatimento de luz. Parece haver nesse trabalho um interesse pela exploração das questões perceptivas da luz a partir de materiais muito elementares.

No caso das manchas (mancha preta/mancha vermelha/mancha branca, 2013) o procedimento de provocar a percepção da paisagem através da criação de um campo cromático é ainda mais intensa; já que existe uma radicalização do uso do material (brilhante) e da cor (saturada). Cada cor detém um padrão vibracional que se impõe à paisagem e, no caso especifico, a experiência expõe-se de maneira contundente, tanto para artista que se propõe a uma imersão radical dentro de cada cor, quanto para a paisagem na medida em que as manchas funcionam como irrupções vibratórias no campo visual. É muito significativa também a relação corpórea que se instaura com a paisagem nessas ações; a artista parece estar interessada em estabelecer relações com a vida da rua a partir de uma dimensão sensível e não racional. Ambos os programas tocam um aspecto da relação com o espaço proposto pela artista que merece ser explorado nessa investigação, é aquele que refere-se a uma dimensão cósmica do espaço. Nessa direção, a cor pode ser entendida como um elemento potencial de rearticulação do espaço, e, considerando a natureza metafisica da luz, seria possível pensar que essas dinâmicas não tocam somente uma dimensão material, mas, também, uma imaterial. 
O programa "Não compro lata velha" que aconteceu entre 2014 e 2015, na cidade do Rio de Janeiro, primeiramente na Rua das Laranjeiras e depois no Grajaú, consistia em:

"Pegar emprestado espelhos com amigos. Amarrá-los nas laterais e espalhá-los pelo chão de uma Kombi utilizada para a compra e venda de ferro-velho. Sentar numa cadeira na caçamba com microfone e livros, acionar o alto-falante do veículo e circular lendo trechos escolhidos. Parar diante de prédios e convidar moradores para vir à janela ver e ouvir." (FABIÃO, 2015, p.241)

A exploração do fenômeno óptico não consistia na única estratégia utilizada pela artista, já que havia também o elemento textual. De todo modo a questão visual é fundamental para o trabalho e a escolha de usar espelho vai no sentido de explorar as questões da luz através de ferramentas remotas, capazes de produzirem fenômenos complexos. Em conversa com a artista, ela referiu-se ao espelho como um enigma, já que este absorve a imagem, para depois expulsa-la. Fabião comentou também uma ação mais recente que é "Singela" (2017) na qual ela saía andando pelas ruas do Rio de Janeiro com dois espelhos de $25 \mathrm{~cm}$ de diâmetro fixados na mão. Ou seja, faz parte da lógica de trabalho da artista explorar os fenômenos a partir de ações muito simples e primárias. Ela refere-se ao trabalho

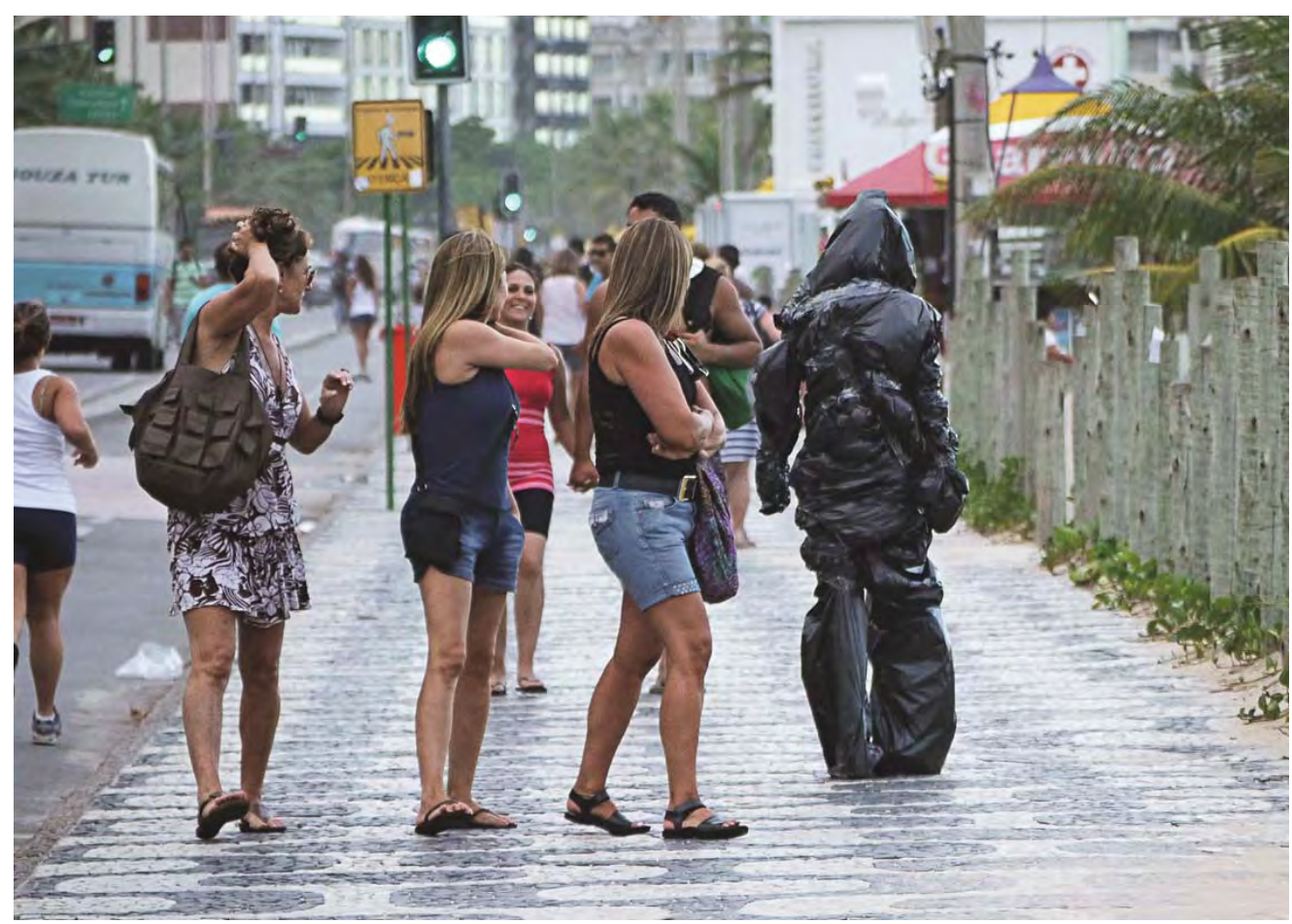

Eleonora Fabião, "Mancha Preta”, 2013, caminhar ensacada pela cidade. Rio de Janeiro. 


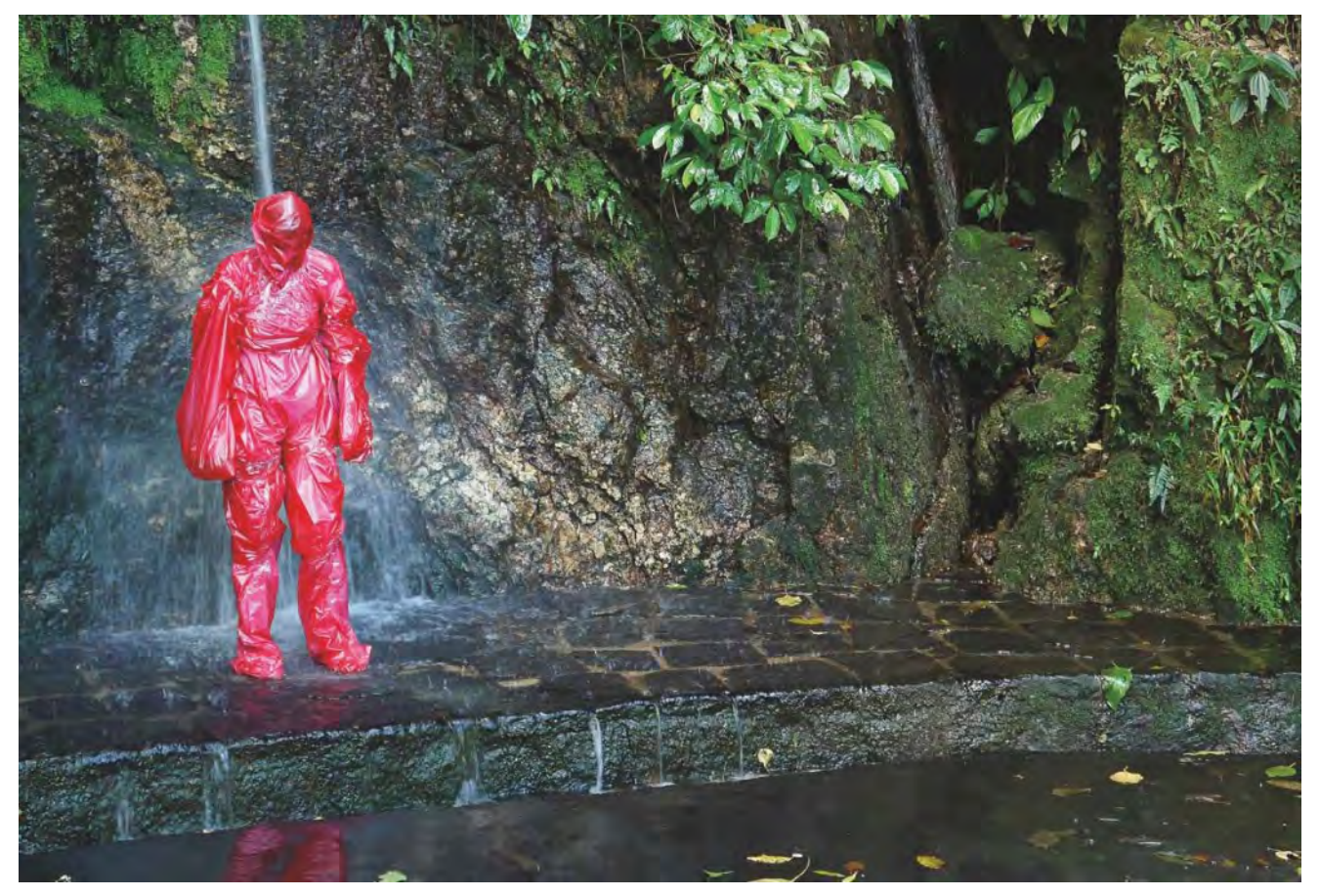

Eleonora Fabião “Mancha Vermelha”, 2013, caminhar ensacada pela cidade. Banhar-me. Rio de Janeiro.

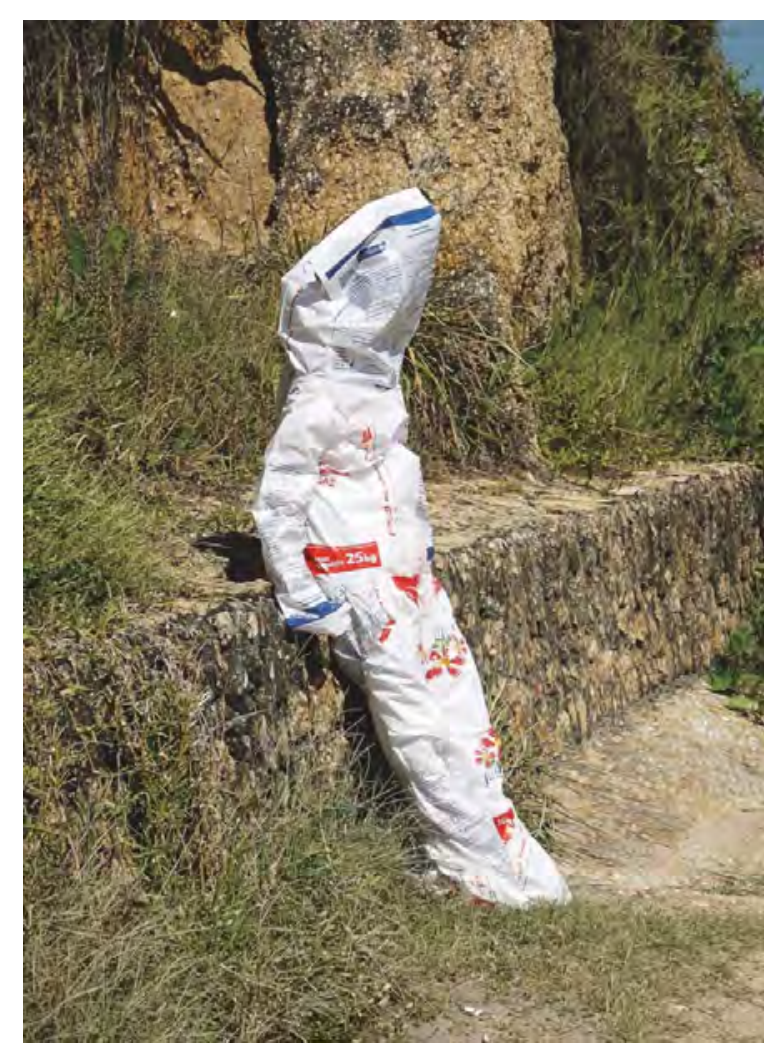

Eleonora Fabião, “Mancha Branca”, 2013, caminhar ensacada pela cidade. Rio de Janeiro.

Fotos: Felipe Ribeiro. Imagem digital; dimensões variáveis.

FONTE: www.premiopipa.com/pag/artistas/eleonora-fabiao/ 
"Não compro lata velha" como uma máquina prismática e conta que a luz irradiada era muito intensa. Além disso ela comenta o cuidado que teve para angulação dos espelhos, para serem vistos de cima em diagonal pelas janelas dos prédios, de forma que aquelas imagens pudessem ativar a potencia do texto lido. Os poetas escolhidos para esse trabalho foram: Arnaldo Antunes, Haroldo de Campos, Wislawa Szymborska e Valère Novarina.

\section{A luz como objeto}

Os programas que serão descritos a seguir compõe o conjunto de ações em que a investigação tentará se aprofundar. Em relação aos trabalhos descritos anteriormente, outras estratégias serão incorporadas: o uso de novos materiais, como por exemplo lâmpadas elétricas de tungstênio e diversos tipos de material reflexivos, e o fato de que essas ações necessitavam da colaboração de um grupo de pessoas para se realizarem. Esses dados geram novas questões para as performances que acabam incorporando algumas soluções de intervenção observadas também no espetáculo "Bom Retiro 985m", a serem apresentadas na sequência. Por exemplo, a operacionalização de algumas demandas técnicas, como é caso de uma bateria móvel de alimentação para as lâmpadas e a orquestração de uma ação coletiva.

A primeira ação desse grupo é "no meio da noite tinha um arco-íris; no meio do arco -íris tem uma noite" (2015), que aconteceu no Rio de Janeiro, e tinha o seguinte programa:

\footnotetext{
"Convidar amigos para fazer uma arco-íris resplandecer na noite da cidade. Mover juntos: 7 longos bambus com 7 lâmpadas de tungstênio coloridas amarradas em suas pontas, todas ligadas por 45 metros de fio a um reversor que, por sua vez, está conectado a uma bateria de caminhão arrastada num carrinho de feira. Tudo e todos seguem noite a dentro."
} (FABIÃO, 2015, p.253)

No escopo de uma análise voltada para a filosofia da cor, este trabalho permite algumas leituras de ordem mais subjetiva. Partindo de Goethe e do encontro entre a luz e a escuridão, onde se formam as cores, o que poderia significar um arco-íris no meio da noite? Em "Cathing the Light" Arthur Zajong dedica um capitulo inteiro à reflexão sobre o arco-íris e, a partir de um traçado histórico sobre as suas simbologias, destrincha toda a investigação cientifica que resultou no entendimento racional do fenômeno. Ele aponta como, culturalmente, o arco-íris simbolizava para diferentes povos a conexão entre Céu e Terra, uma ligação entre esses dois planos. 0 autor se utiliza desse fenômeno especifico como exemplo para uma análise mais ampla; sobre como a maneira que o fenômeno é percebido está atrelada a um tipo de mentalidade social e de imaginação acerca da luz. 


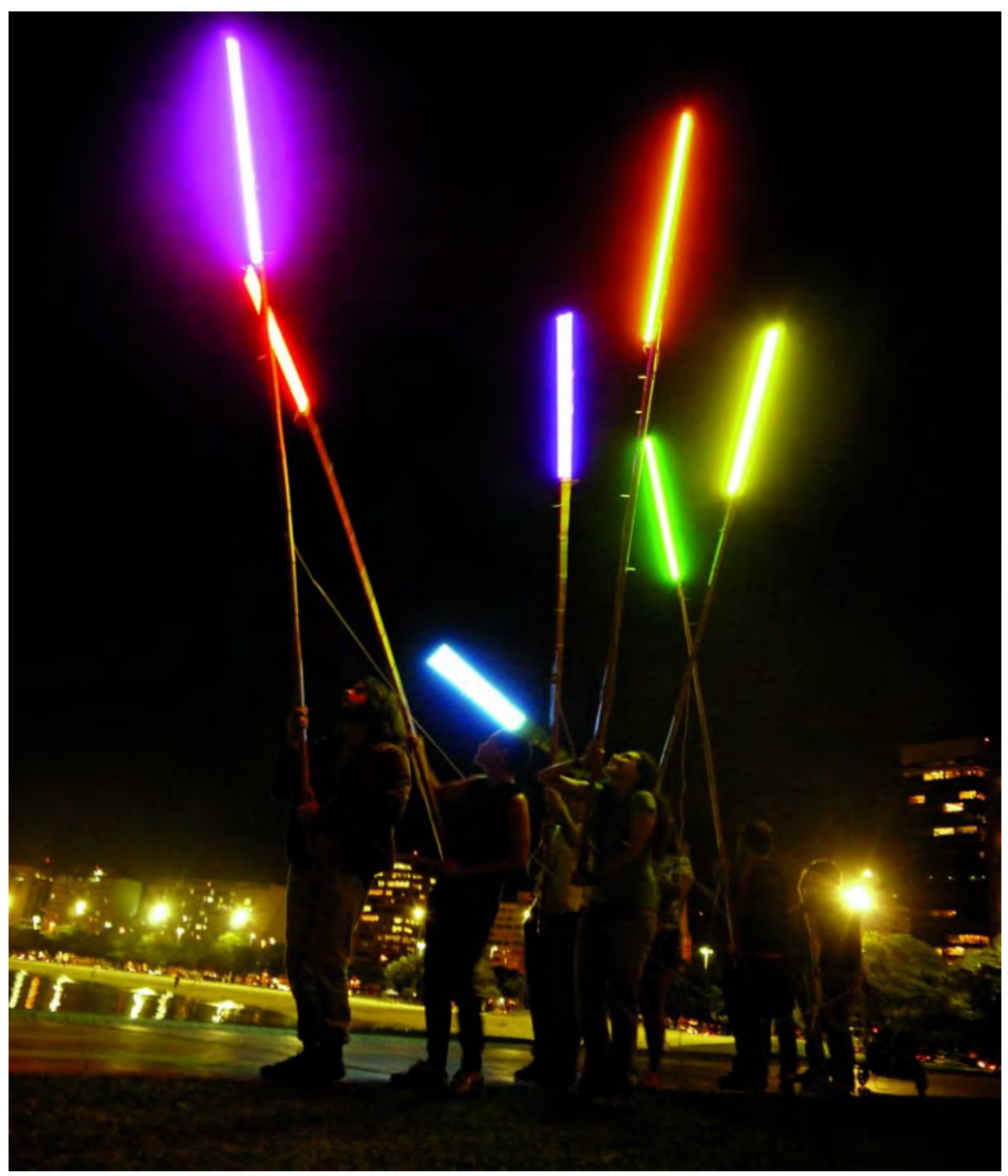

Eleonora Fabião, "no meio da noite tinha um arco-íris, no meio do arco-íris tem uma noite"

Rio de Janeiro, 2015.

Clara Acioli, Gunnar Borges, Pedro Gualda, Sissi Mazzetti, Cinthia Mendonça, José Ricardo Monteiro Neto, Elisa Peixoto, Luiza Rangel, Renata Teixeira e André Telles.

Foto: Jaime Acioli. Imagem digital; dimensões variáveis FONTE: www.premiopipa.com/pag/artistas/eleonora-fabiao 
"É preciso que, nós mesmos, imaginemos a luz e o mundo como algo mais rico e profundo do que a imaginação mecânica pode captar. Goethe, entre outros, advogava tal entendimento. Com cuidado, e não medo, eles enxergavam um caminho por onde a fisicalidade pudesse se abrir para o espiritual." (ZAJONC, 1993,p.185) ${ }^{6}$

0 autor acredita que partimos de um tipo de consciência que enxergava o arco-íris como uma aliança com o sagrado, até como uma deusa em si, e passamos a entende-lo como um simples fenômeno efêmero que se dá pela refração da luz através da chuva. Ao longo de todo o livro ele se dedica a refletir como nossa imaginação acerca da luz foi alterada, apontando a forma como teria havido a substituição de uma compreensão antiga e imaginativa do mundo pela visão da ciência contemporânea. Zajonc defende a recuperação de uma capacidade imagética da luz mais profunda e enriquecedora do que simplesmente uma imaginação mecânica e racional. Nesse sentido ele aponta para a compreensão espiritual que Goethe tinha sobre os fenômenos físicos e naturais.

Retomando a performance de Fabião "no meio da noite tinha um arco-íris; no meio do arco-íris tem uma noite", e tentando relacioná-la com as questões propostas por Zajonc, uma leitura possível do trabalho é de que uma existe uma provocação para um novo tipo de imaginação acerca do arco-íris. Dentro dessa perspectiva, é importante destacar que essa concepção não estaria associada somente à questão técnica de se produzir à noite, através de luz artificial, as sete cores do arco-íris. Existe uma qualidade artesanal inerente ao programa, e também o fato de ser realizado em grupo, que parece imprimir à ação um sentido bastante urgente de conexão com o aqui e agora.

As questões que surgem nessa performance vão ser determinantes para um próximo programa elaborado em Nova Iorque em ocasião da residência que Fabião fez na Performa 15. Trata-se de uma série de ações elaboradas para o Financial District, também conhecido como Wall Street: "Things That Must Be Done Series [TTMBDS]" / "Série de coisas que precisam ser feitas [SCQPSF]". A série foi composta pelas cinco ações descritas abaixo:

[SCQPSF] Wall Street Action \#1: asphalt snake / cobra de asfalto dia 1 do mês 11

6 "It requires that we imagine light, ourselves, and the world as richer and deeper than the mechanical imagination can capture. Goethe, among others, advocated such understanding. With care, but not fear, they sought a way that the physical might open out on the spiritual." (tradução livre da autora) 
Mover uma cobra de asfalto pelas imediações da bolsa de valores da capital do capital às $11 \mathrm{~h}$ da manhã e às 11 da noite. Essa cobra muda de rabo e de cabeça permanentemente e, por vezes, perde o rabo e a cabeça. Essa criatura do asfalto é uma articulação de 7 varas de bambu paralelas ao chão - 4,3m cada, 30,1m no total - e um grupo de pessoas. As pessoas, colaboradores e passantes, se deslocam segurando os bambus pelas pontas, passando os bambus adiante e os recebendo de volta, movendo-se ao longo do movimento, acompanhando de perto ou de longe, alternando entre essas possibilidades.

[SCQPSF] Wall Street Action \#2: clothesline / varal dia 2 do mês 11

Meio-dia, sol no meio do céu. Conectar as 7 varas de bambu pelo topo com uma linha fina de algodão de $12 \mathrm{~m}$. 0 formato final é o de um varal. Amarrar ao longo da linha dezenas e dezenas de tiras de fita metaloide prateadas e douradas como numa rabiola de pipa. Quando o sol chegar exatamente no meio do céu, caminhar pela Wall Street. Fazer brilhar.

[SCQPSF] Wall Street Action \#3: almost monochromatic / quase monocromatico

dia 3 do mês 11

Crepúsculo. Mover uma nuvem de luz quase monocromática nos arredores da bolsa de valores da capital do capital. Cruzar o poente e adentrar a noite. Atar 7 lâmpadas de tungstênio no alto dos bambus. Todas são da mesma cor (diferentes tons de rosa), exceto uma (amarela). Todas estão ligadas por $45 \mathrm{~m}$ de fio a um reversor que, por sua vez, está conectado a uma bateria arrastada num carrinho de carga.

[SCQPSF] Wall Street Action \#4: Rothko's pallet / paleta do Rothko dia 4 do mês 11

Alvorada. Os 7 bambus estão recobertos com lycra - a cor de cada cor, a quantidade de cada cor e a sequência de cores são inspiradas em 7 pinturas de Mark Rothko. Caminhar em grupo. Caminhar só. Ver o despertar das cores. 
[SCQPSF] Wall Street Action \#5: in the middle of the night there was a rainbow, in the middle of the rainbow there is a night / no meio da noite tinha um arco-íris; no meio do arco-íris tem uma noite dia 5 do mês 11

Meia-noite, sol no meio do céu do lado de lá. ${ }^{7}$

Considerando as questões acerca da luz como eixo principal dessa série, a primeira coisa que se destaca nessas ações é um alinhamento bastante determinante com relação aos horários do dia e da noite para sua realização, ou seja, as premissas do trabalho parecem estar conectadas a um sentido cósmico dos ciclos de luz. No texto disponibilizado pela artista para o site do Premio Pipa, Fabião afirma que as ações são arquitetadas de acordo com arranjos numerológicos muito específicos. Parece existir a intenção de expandir a conexão com o aqui e agora e de resgatar, mais uma vez citando Zajonc, novas imaginações para a luz. Sem dúvida, outra escolha bastante determinante para o trabalho é o fato de essas ações serem realizadas em Wall Street, ampliando ainda mais essa dimensão de resgate do aqui e agora, já que o trabalho acaba sendo endereçado para um público cujo tipo de experiência de vida é pautada majoritariamente pelo trabalho, pelo dinheiro e por um olhar racionalizado e desconectado dos ciclos da natureza.

A primeira ação, "cobra de asfalto", configura-se como uma preparação para que as outras ações possam ocorrer. De todas as ações é a que tem maior duração e a razão disso parece ser a necessidade de despertar um campo conectivo para que as outras ações possam ser recebidas pelo espaço. "Coisas que precisam ser feitas" é uma série em que as ações estão muito amarradas umas às outras e isso se apresenta de maneira bastante explicita; as questões fenomenológicas acerca da luz apontam para uma chave importante do trabalho. No segundo dia a ação "varal", que acontece em pleno sol a pino e se utiliza de fitilhos prateados e dourados para refletir e irradiar a luz do sol, um material extremante reluzente que 'como rabiolas de pipa', liga os bambus uns aos outros. É interessante a escolha de começar o ciclo com a luz do Sol, símbolo maior de poder. As leituras simbólicas que podem ser feitas sobre o significado do dourado e prateado dos fitilhos são inúmeras; no entanto parece que a intenção está mais relacionada com um tipo de experiência sensível e fisiológica da luz. Existe nessa série um tipo de proposição para a experiência dos

7 <http://www.premiopipa.com/pag/artistas/eleonora-fabiao/, acessado em 29/03/2017. 
fenômenos físicos da natureza que remonta ao engajamento ativo no mundo, proposto por Goethe, uma espécie de interação que, segundo ele, seria formativa e profundamente educativa.(ZAJONC, 1993, p.205.)

A ação que dá sequência ao programa é "quase monocromático" e ilustra muito bem essa relação já que o crepúsculo, horário escolhido para ação, é um exemplo maravilhoso de uma situação em que o olho opera sua vivacidade de maneira intensa. A nuvem monocromática, construída por diferentes matizes da cor rosa, atravessa o por do sol; as lâmpadas são acesas no poente, quando ainda há luz solar e vão adentrando o escuro. A medida em que vai escurecendo as pupilas vão dilatando gradualmente e a cor vai tomando corpo, vai se intensificando. No entanto, a referencia simbólica ao sol permanece e existe uma lâmpada amarela que tenciona esse campo cromático rosa que foi construído. Na direção desse tipo de experiência poética visual, que explora aspectos fisiológicos da luz e da cor, incorporando uma dimensão cósmica, poderíamos nos aproximar de um artista como James Turrel e suas conhecidas aberturas de observação do céu em meio à estímulos de luz artificial. No entanto, Turrel, em suas experiências, cria recortes e molduras dentro e fora dos espaços expositivos; propondo espaços protegidos e de imersão. Fabião vai numa direção oposta, onde a experiência fisiológica é somada a outras camadas do espaço urbano; é um trabalho de ativação do meio que só pode acontecer na rua, estando nesta circunstância a força de sua atuação.

A ação "paleta Rothko" acontece com sol nascente, as matizes de cores inspiradas nas telas do pintor são construídas nos bambus com a lycra colorida; é interessante notar que o despertar das cores é construído por meio de um movimento ocular oposto ao que se operou no crepúsculo. Nesse sentido as cores são despertadas pelo sol e vão surgindo da escuridão. Sobre o material escolhido para a ação, a lycra, a artista comenta que o interesse está no fato de que é um tecido que consegue absorver a luz e rebate-la com intensidade, comparando-a com um espelho.

A ação seguinte "no meio da noite tinha um arco-íris, e no meio do arco íris tinham uma noite" que refere-se à performance ocorrida anteriormente no Rio de Janeiro, finaliza a série resgatando o que parece ser uma chave importante em todos esses trabalhos, ou seja, a dicotomia entre luz e escuridão, e de como as cores estão atreladas à percepção sensível do olho. Da mesma forma que em "quase monocromático" a força da ação não está nas lâmpadas em si, mas na maneira como esse arco-íris simbólico é composto por lâmpadas e pessoas, e em como ele(s) desloca(m)-se pela rua; assim como na corporeidade dos materiais escolhidos e na sua precariedade. "Coisas que precisam ser feitas" pode ser pensada como um convite para um tipo de imaginação da luz aliada a uma compreensão maior do cosmos. 
"SCQPSF é cronopoética e cronopolítica. É também cronóptica.

SCQPSF é uma meditação sobre abstracionismo e concretude, bruxaria e arte, capitalismo e obscurantismo, bruxaria e capitalismo.

SCQPSF performa, abertamente, uma luta entre lucro e gratuidade, eficiência- eficácia-efetividade e experimentação, estandardização e imaginação política, normatividade e vitalidade. Queremos arte se movendo 4 metros acima das nossas cabeças. Queremos ver raro brilhar." ${ }^{8}$

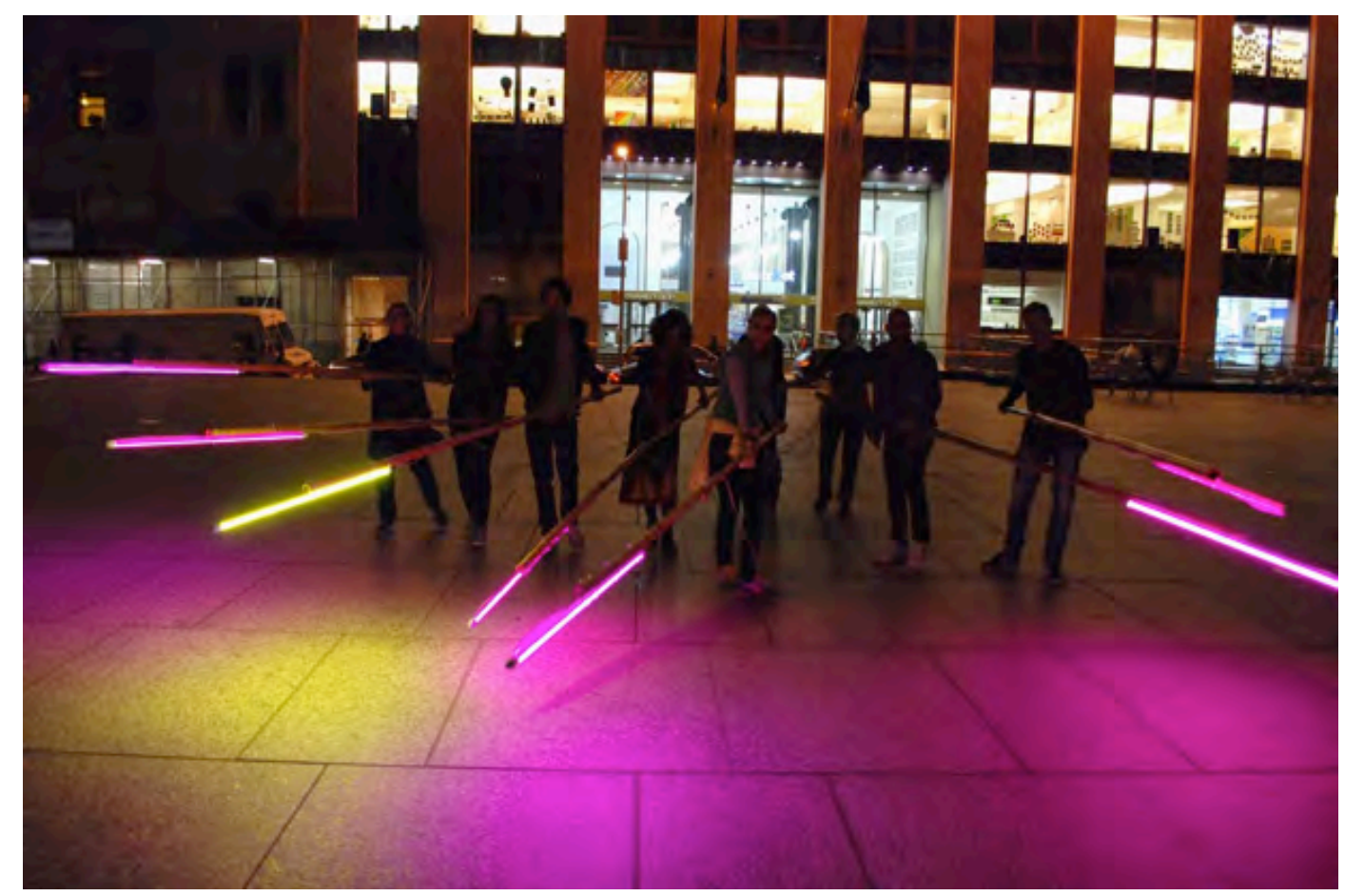

Eleonora Fabião, [SCQPSF] WALL STREET ACTION \#3: almost monochromatic (AÇÃO WALL STREET \#3: quase monocromático)

Colaboradores: Viniciús Arneiro, Sebastián Calderón Bentin, Frances Cooper, Pablo Assumpção B. Costa, Liz Heard, Irene Hultman, Bettina Knaup, André Lepecki, Krystalla Pearce, Felipe Ribeiro e Cecilia Roos.

Performa Biennial, Nova York, 2015.

Foto: Felipe Ribeiro. Imagem digital; dimensões variáveis FONTE: www.premiopipa.com/pag/artistas/eleonora-fabiao/

8 http://www.premiopipa.com/pag/artistas/eleonora-fabiao/,acessado em 29/03/2017) 


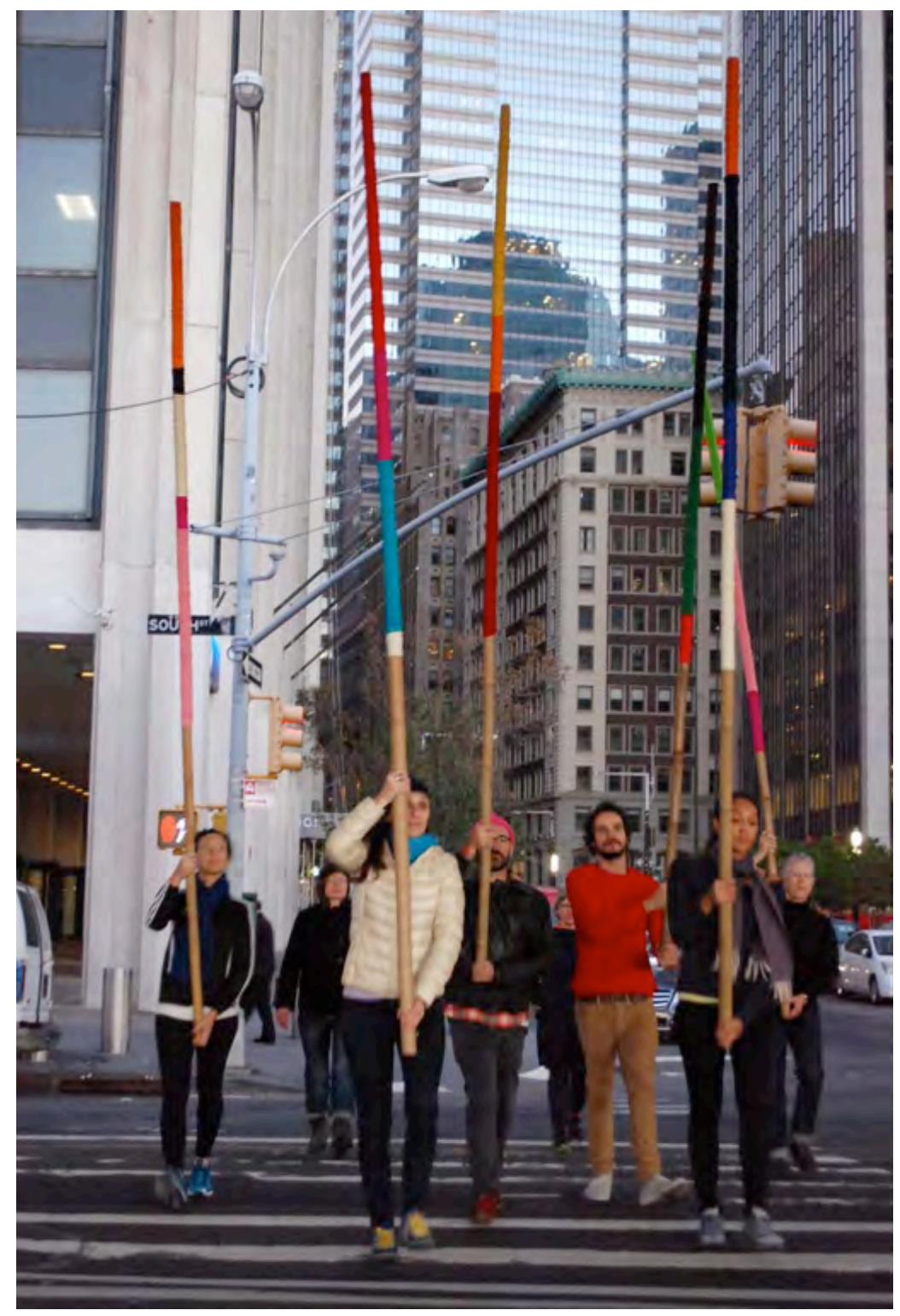

Eleonora Fabião, [SCQPSF] WALL STREET ACTION \#4: Rothko's pallet (AÇÃO WALL STREET \#4: paleta do Rothko)

Colaboradores: Viniciús Arneiro, Sebastián Calderón Bentin, Frances Cooper, Pablo Assumpção B. Costa, Liz Heard, Irene Hultman, Bettina Knaup, André Lepecki, Krystalla Pearce, Felipe Ribeiro e Cecilia Roos.

Performa Biennial, Nova York, 2015.

Foto: Felipe Ribeiro. Imagem digital; dimensões variáveis FONTE: www.premiopipa.com/pag/artistas/eleonora-fabiao/ 


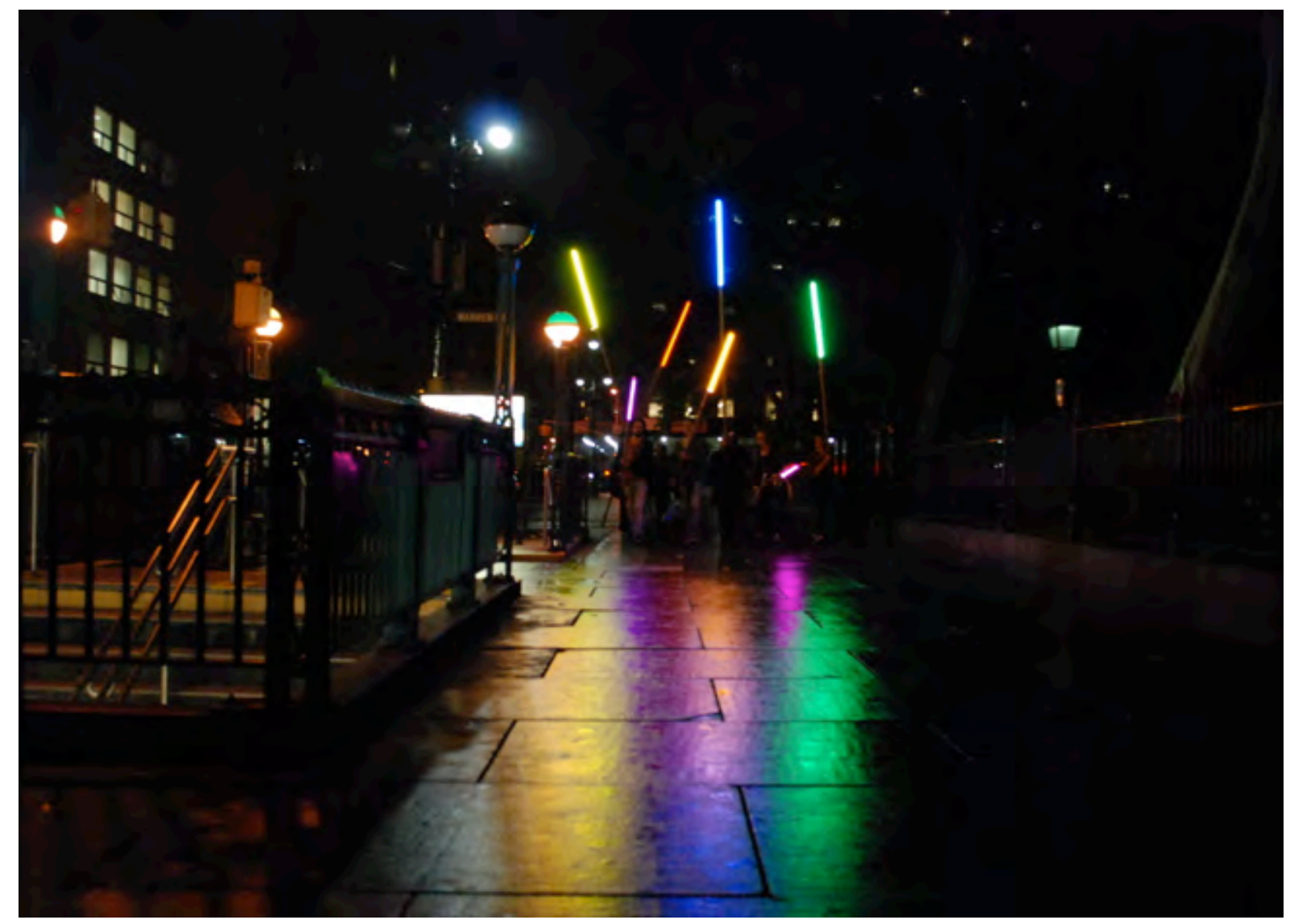

Eleonora Fabião, [SCQPSF] WALL STREET ACTION \#5: in the middle of the night there was a rainbow, in the middle of the rainbow there is a night

(AÇÃO WALL STREET \#5: no meio da noite tinha um arco-íris, no meio do arco-íris tem uma noite)

Colaboradores: Viniciús Arneiro, Sebastián Calderón Bentin, Frances Cooper, Pablo Assumpção B. Costa, Liz Heard, Irene Hultman, Bettina Knaup, André Lepecki, Krystalla Pearce, Felipe Ribeiro e Cecilia Roos.

Performa Biennial, Nova York, 2015.

Foto: Felipe Ribeiro. Imagem digital; dimensões variáveis

FONTE: www.premiopipa.com/pag/artistas/eleonora-fabiao/ 


\section{Azul, azul, azul e azul}

O próximo trabalho escolhido para compor essa análise é “azul, azul, azul e azul”, realizado em junho de 2016 e composto por uma série de cinco ações - que aconteceram de 3 em 3 horas, a partir das 6:00 e que se configuraram como caminhadas, pelas ruas da Colônia Juliano Moreira - hoje Instituto Municipal de assistência à Saúde Juliano Moreira - que foi uma instituição criada na primeira metade do século XX para abrigar pessoas classificadas como anormais e indesejadas pela sociedade, localizada em Jacarepaguá, na cidade do Rio de Janeiro. As ações aconteceram no dia da abertura da exposição "Das Virgens em Cardumes e a Cor das Auras" no Museu Bispo do Rosário Arte Contemporânea, contaram com um grande grupo de colaboradores e envolveram as áreas interna e externa do museu a partir da entrada e saída de três obras do Bispo escolhidas para figurarem a proposta, que são:" Manto da Apresentação", barco "Vela Roxa" e o jaquetão "Eu vim". Segue-se a descrição das cinco ações:

\section{6:00h.}

Com o Manto da Apresentação de Arthur Bispo do Rosário sobre um andor e sob uma cúpula, caminhar ao redor do Museu Bispo do Rosário. Fazer um anel em torno do prédio. Na volta, posicionar o Manto no espaço expositivo.

\section{9:00h}

Com a embarcação Vela Roxa de Arthur Bispo do Rosário, sombreada com tecido azul e sob uma cúpula num andor, cruzar e ligar dois portais: a entrada da Colônia Juliano Moreira e a entrada da Escola Municipal Juliano Moreira. Fazer frota, fazer cardume, fazer mar. Na volta, posicionar a embarcação no espaço expositivo.

\section{Meio-dia}

Uma corda de sisal de 30 metros foi recoberta com diversos tecidos azuis - foi customizada duas semanas antes na Praça do Anil numa manifestação no Dia Nacional da Luta Antimanicomial com a ajuda de participantes do evento. Caminhar tencionando a corda na rua principal da Colônia e nas obras da via Transolímpica - não deixar a corda tocar no chão, não deixar o chão tocar na corda. Formar geometrias de bandos de aves. Na volta, posicionar a corda no espaço expositivo. 


\begin{abstract}
15:00h
Sete varas de bambu de 3,4m de altura, $12 \mathrm{~m}$ de linha de algodão e dezenas e dezenas de tiras de fita metaloide azul. As tiras estão amarradas como rabiola de pipa na linha de algodão que, por sua vez, conecta os bambus como um varal. Caminhar com a franja desde o Museu Bispo do Rosário até o Núcleo Ulisses Viana onde está localizada a cela de Arthur Bispo do Rosário. Circundar o muro do local. Parar em frente ao portão e deixar a franja cintilar, reluzir, ressoar. Na volta, posicionar a composição no espaço expositivo.
\end{abstract}

\title{
18:00h
}

Caminhar do Museu Bispo do Rosário até o Núcleo Histórico da Colônia Juliano Moreira. 0 caminho é iluminado por sete lâmpadas de tungstênio em sete diferentes tons de azul atadas a sete varas de bambu de 3,4 m cada, ligadas por $45 \mathrm{~m}$ de fio a um reversor que, por sua vez, está conectado a uma bateria de caminhão puxada num carrinho. No meio do centro do Núcleo Histórico o Jaquetão EU VIM está à espera, suspenso num andor e protegido sob uma cúpula. Caminharmos todos juntos de volta para o Museu. O caminho é iluminado por sete anjos azuis. (FABIÃO, 2017, p100)

Sobre essa proposta a primeira coisa que chama atenção - na perspectiva que esta sendo construída - é a idéia de ações que estão atreladas ao movimento cíclico do sol e portando pensadas para acontecerem em horários específicos. Mais uma vez vale ressaltar que a descrição de um trabalho dessa natureza, na maior parte das vezes, é insuficiente para dar conta daquela experiência. Na oportunidade em que tive de conversar com uma pessoa que havia participado dessas ações, a primeira coisa que ela me disse foi: 'nunca havia enxergado em toda minha vida tantos tons de azul'. A declaração chama atenção para o sentido e a força do trabalho, possivelmente instransponível para uma reflexão como essa, de natureza dissertativa.

Outra coisa que se revela nos escritos da artista sobre esse programa - e que faz parte da natureza de todos os seus programas - é a vontade de dialogar não somente com a obra do Bispo, mas também a intenção de movimentar essa obra dentro do contexto politico e social da Colônia Juliano Moreira. À época da exposição a região na qual está inserida 
ainda sofria os impactos e prejuízos das desastradas obras destinadas à Olimpíada do Rio de Janeiro, que havia acontecido naquele mesmo ano. Por exemplo, uma rodovia separou a colônia do Museu, o Museu do Polo Experimental de Convivência, Educação e Cultura, bem como do Núcleo Histórico. O programa que propôs a saída das obras do Bispo pelas ruas da Colônia a partir da articulação de um coletivo de pessoas tinha também intenção transformar os modos de criar, produzir, exibir e de agir institucionalmente. De forma que, por fim, a equipe aderiu a ideia pouco usual de abrir a exposição às 5:30 min, além de organizarem transporte, hospedagem e alimentação para os visitantes na própria Colônia; transformando aquele espaço e os momentos entre as ações em uma vivência muito significativa.

É relevante para essa dissertação que a artista, neste trabalho, também se utilize de dispositivos que atuam na fisiologia do olho e em relação à percepção das cores, no caso específico, o azul. São exploradas diferentes tipos de ferramentas: rebatimentos, filtros, espelhamentos e lâmpadas de diferentes matizes. Mas existe uma diferença essencial entre as duas propostas, porque se em "Coisas que tem que ser feitas" a vontade de ampliação da dimensão cósmica da vida parte de um experiência urbana, e existe um profusão prismática de elementos, aqui o chamado é à imersão. A articulação que se pretende com o espaço está norteada pelo sentido da obra do Bispo, e a escolha do azul vai nessa direção. 0 azul parece propor um mergulho na dimensão espiritual da obra e na existência de Artur Bispo do Rosário:

\footnotetext{
"E, famosamente, só deixou entrar em sua cela aqueles que responderam corretamente à pergunta: "Qual a cor de minha aura?" Se não dissessem "azul", não entravam. Azul como os fios desfiados de uniformes e lençóis do hospital que utilizou para fazer seus bordados. Azul como os sete anjos que viu no dia de sua revelação na casa da Família Leone, em Botafogo, bairro do Rio de Janeiro, onde trabalhava como faz tudo." (FABIÃO, 2017, p. 95)
}

Fabião entrou em contato com a obra do artista ainda bem jovem e ela descreve o encontro com o "Arquivo de tudo que existe no mundo" - que seria a dimensão total da obra do artista - como alguma coisa que tocou-lhe profundamente. De forma que uma grande parte do seu estudo de Doutorado será dedicada à potencia estética e política dessa obra, nas palavras da artista, sobre a energética do paradoxo: " Fez o que fez, fez o impossível, transformou o lixo fascista em tesouro poético- político". Em seus textos sobre Bispo do Rosário, Fabião, muitas vezes, ou quase sempre, refere-se à ele e à sua obra por meio de analogias com a luz. É de conhecimento público que foi a partir de uma visualização, aparição, revelação que Artur Bispo desenvolve a trajetória a culminar em sua internação. 
"Bispo simplesmente apareceu naquela noite azul de dezembro. Bispo -aparição. 'Aparição' - saimento, manifestação, revelação, assombração - é, pois, um nexo, um modo, uma corrente, uma eletricidade no trabalho - corpo - vida Bispo do Rosário. 0 inventário vibrabrilha aparição." (FABIÃO, 2017, p. 96)

Dentro desse contexto parece natural que, entre tantos expedientes que a artista poderia ter escolhido para a performance, ela proponha esse diálogo com a obra de Bispo através da relação entre o corpo e a luz. A hipótese aqui levantada é de que existe uma qualidade inerente à luz que esta ligada à questão existencial da vida e que, no caso, está relacionada ao corpo da obra de Bispo do Rosário. E nesse sentido a luz será entendida como um corpo próprio, parafraseando James Turrel: "a luz não é tanto alguma coisa que revele, pois é em si a revelação". (ZAJONC, 1993, p.324) Entre as diversas referências que Fabião traz na escolha dos materiais propostos talvez a mais clara sejam a das 7 lâmpadas em referência aos sete anjos que ele teria visto na noite de sua revelação.

É oportuno retomar aqui a reflexão que Zajonc propõe sobre como nosso entendimento da luz é revelador da natureza e do tipo de construção mental de uma sociedade. 0 autor afirma que cada imaginação sobre a luz está contida em uma imaginação cultural sobre o homem e o mundo. Assim, os hábitos da nossa cultura e os dogmas da nossa educação determinariam nossa visão. Ele defende que o verdadeiro artista, cientista ou sacerdote, não deveria se ater ao conhecimento como objeto e sim enquanto experiência. Sobre os desdobramentos da física moderna e contemporânea na tentativa de encontrar alguma resposta objetiva acerca da materialidade da luz, Zajonc aproxima-se mais uma vez de Goethe:

\footnotetext{
"Goethe estava certo. Mesmo que nós tentemos dividir a luz em pedaços atômicos fundamentais, ela ainda permanecerá inteira no final (...) Talvez, para a luz, pelo menos, a ferramenta mais fundamental não se encontre na pequeneza, mas sim na inteireza, a sua incorrigível capacidade de ser uma e muitas, partícula e onda, uma coisa única com o universo dentro de si." (ZAJONC, 1993, p.299) ${ }^{9}$
}

9 "Goethe was right. Try though we may to split light into fundamental atomic pieces, it remains whole to the end (...) Perhaps for light, at least, the most fundamental feature is not to be found in smallness, but rather in wholeness, its incorrigible capacity to be one and many, particle and wave, a single thing with the universe inside." (tradução livre da autora) 


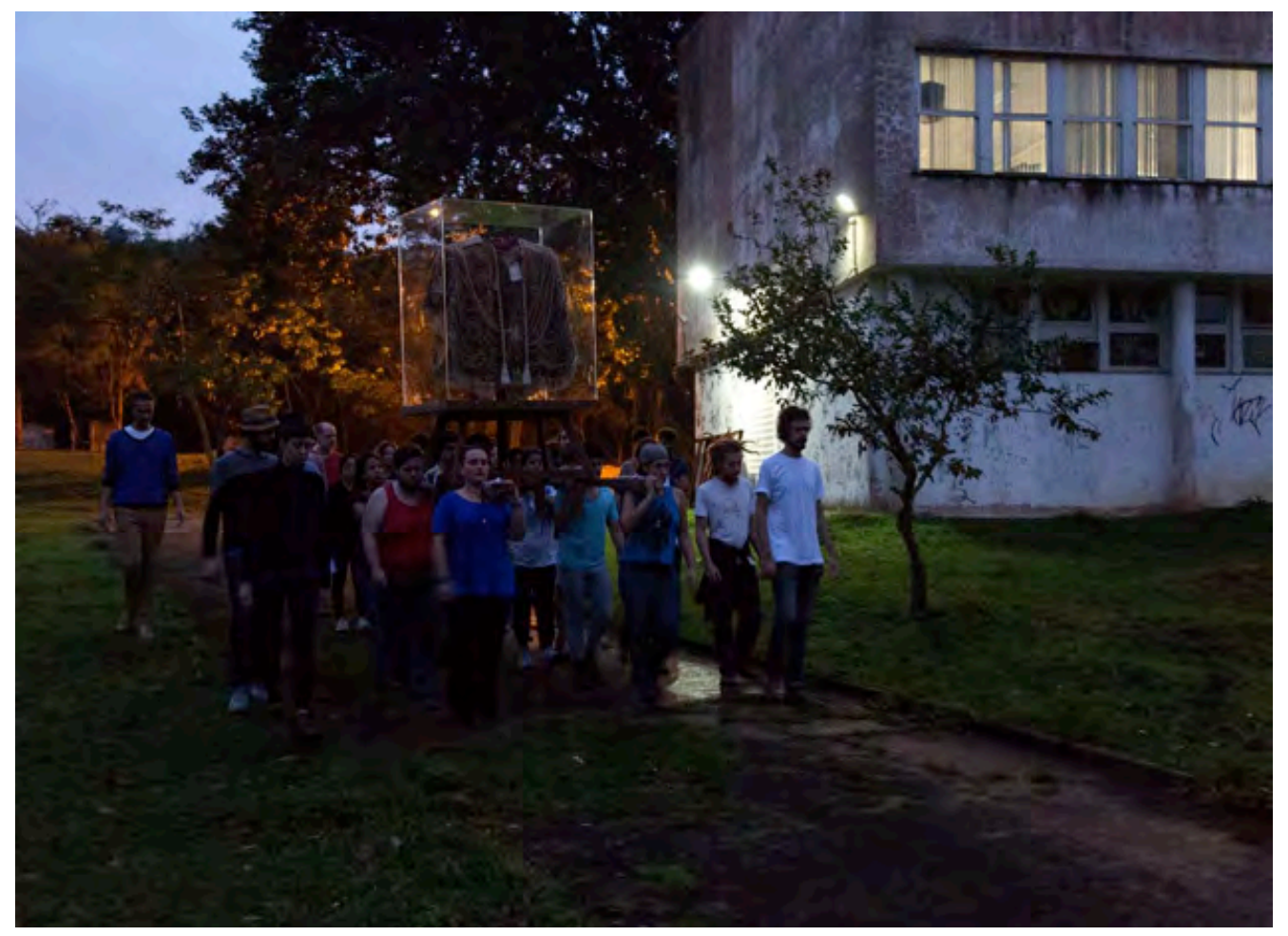

Eleonora Fabião, azul 6, 2016.

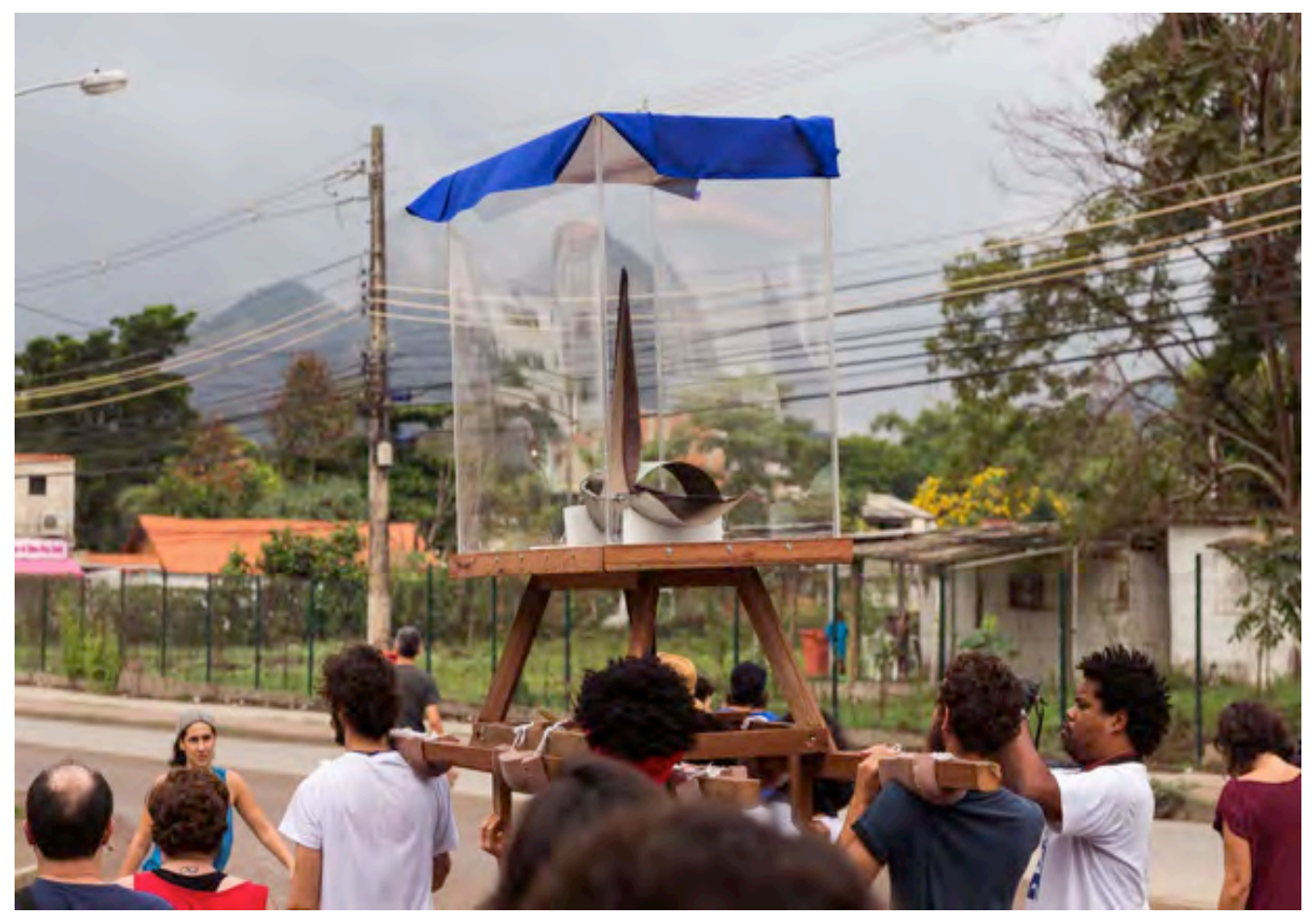

Eleonora Fabião, azul 9, 2016. 


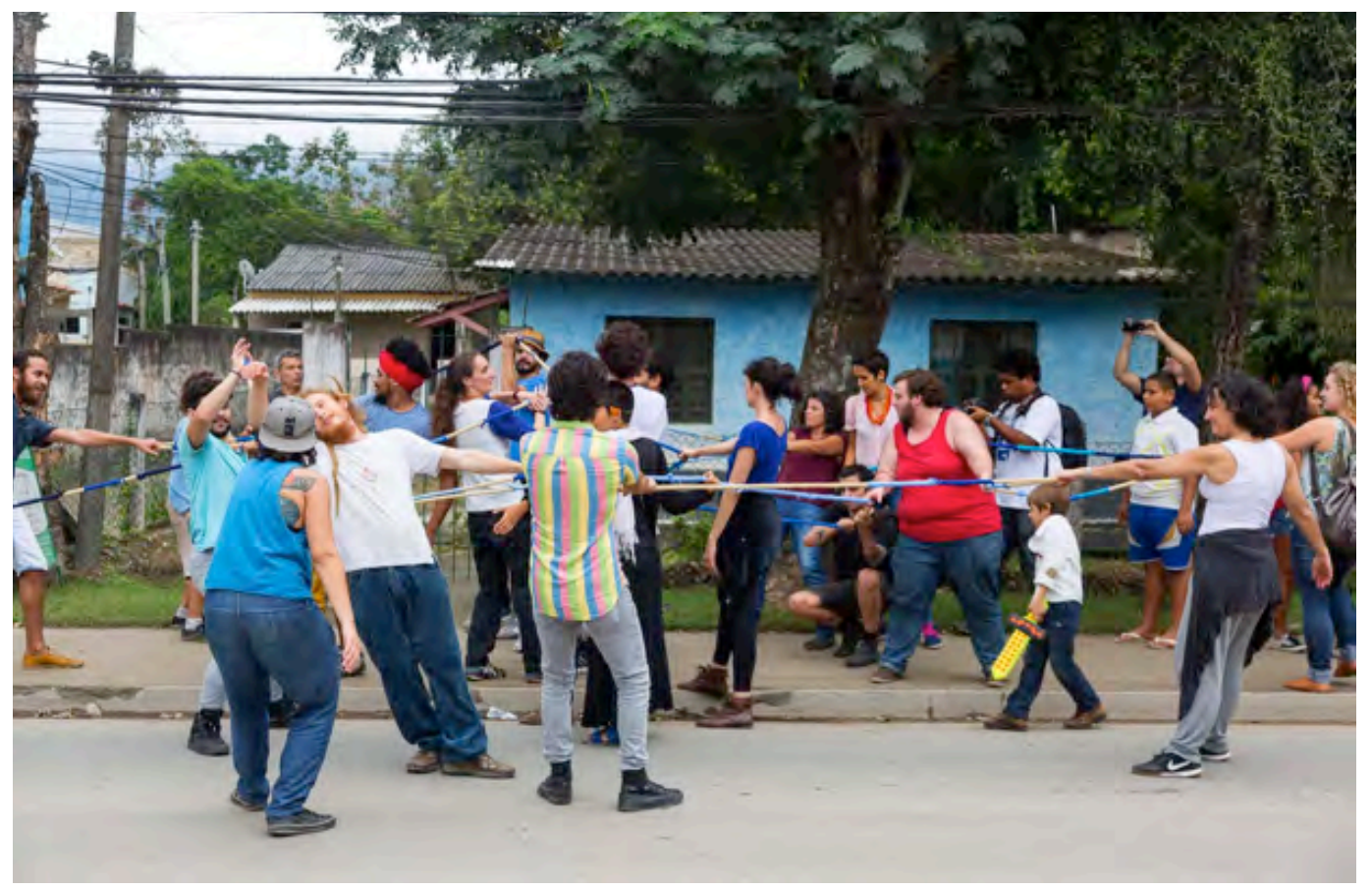

Eleonora Fabião, azul 12, 2016.

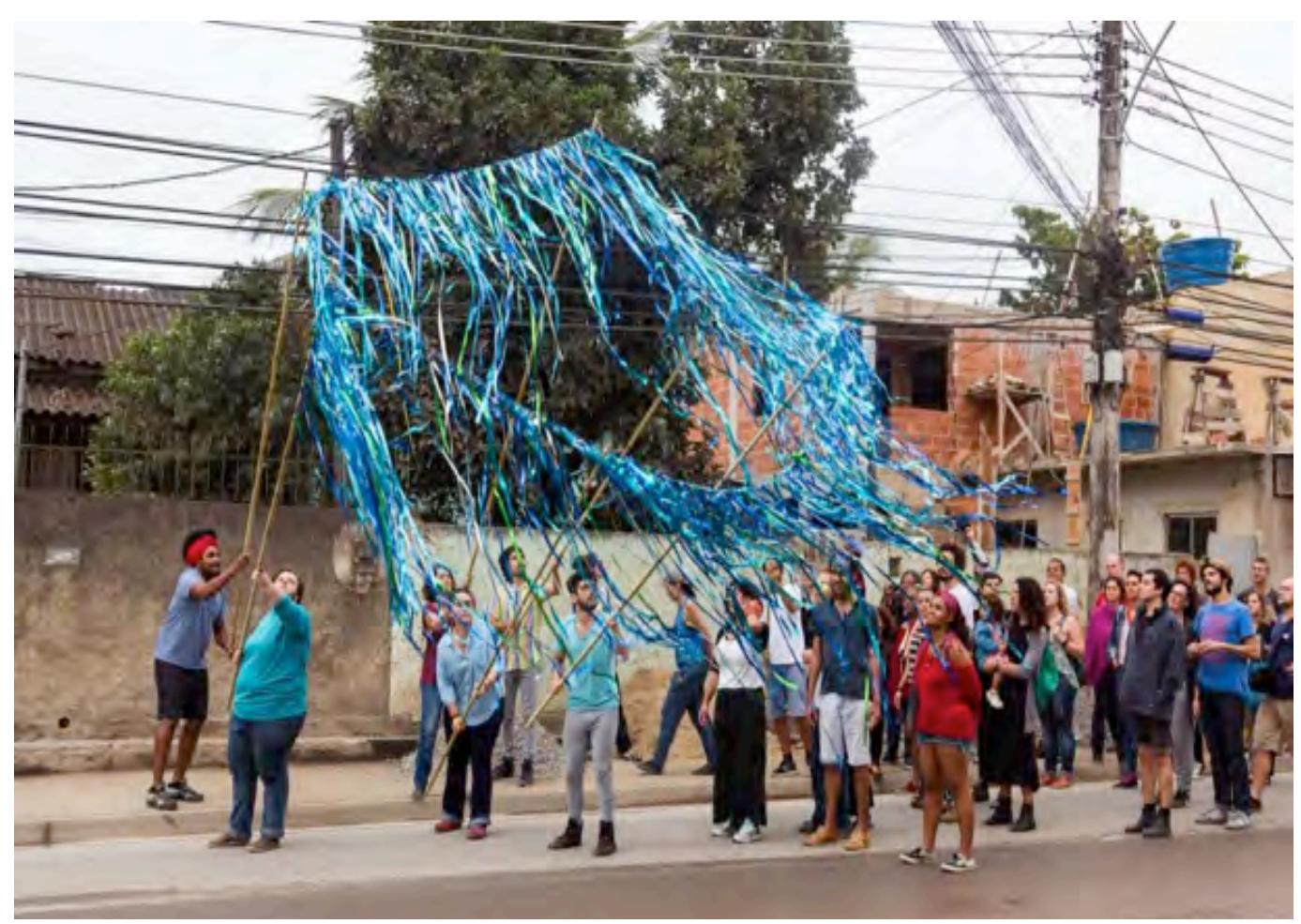

Eleonora Fabião, azul 15, 2016. 


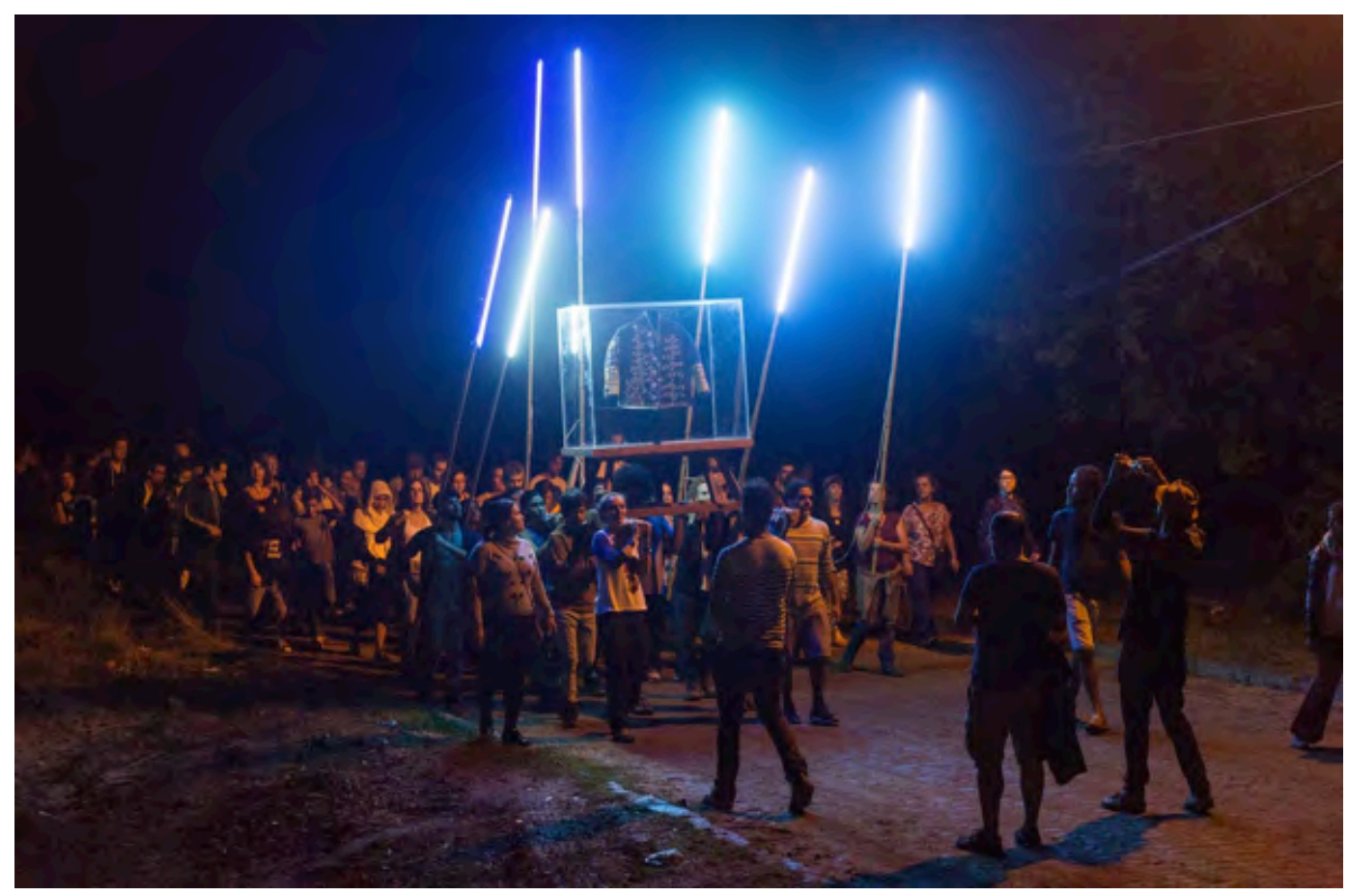

Eleonora Fabião, azul 18, 2016.

Colaboradores: Dominique Arantes, Viniciús Arneiro, Gunnar Borges, Lucas Canavarro, Elilson, Thiago Florêncio, André Lepecki, Luar Maria, Gabriel Martins, Dieymes Pechincha, Elisa Peixoto, Rúbia Rodrigues, Adriana Schneider, Miro Spinelli, André Telles e Mariah Valeiras.

Co-realização: Museu Bispo do Rosário.

Exposição Das Virgens em Cardumes e a Cor das Auras, Museu Bispo do Rosário.

Fotos: Jaime Acioli.

FONTE: www.premiopipa.com/pag/artistas/eleonora-fabiao/

Esse capítulo pretende trazer experiências artísticas que se utilizaram da luz como ferramenta para estabelecer relações com o espaço urbano em que estavam inseridas. A obra de Eleonora Fabião propõe algumas questões por meio da luz de forma bastante poética, e suas ações, mesmo que determinadas por um programa pré-estabelecido, não deixam de estar inseridas no campo da performance. A seguir, a ideia é aproximar dessa prática performática as experiências propostas pelo iluminador Guilherme Bonfanti no espetáculo teatral "Bom Retiro 985 metros” e na relação deste com a cidade. 


\subsection{A EXPERIÊNCIA COM A LUZ DA CIDADE EM BOM RETIRO 985 METROS.}

A intenção aqui é propor uma reflexão sobre a luz como elemento potencial de articulação do espaço urbano a partir experiência do espetáculo 'Bom Retiro 958 metros', desenvolvida pelo iluminador Guilherme Bonfanti. Ao longo de vinte anos de parceria colaborativa junto do Teatro da Vertigem, Bonfanti construiu um importante repertorio de projetos site-specific desenvolvidos a partir de uma linguagem própria, e incorporando aos tradicionais equipamentos de iluminação o uso dos mais diversos tipos de objeto que se relacionam com o espaço especifico em questão. A escolha desse espetáculo específico é relevante para a pesquisa porque, nessa montagem em particular, a dimensão da rua e a experiência de imersão no espaço urbano foram elementos diferenciais em relação a outros projetos do Teatro da Vertigem. "Bom Retiro 985m" configurou-se como uma experiência de intervenção urbana e, nesse sentido, o projeto de luz executado na montagem relacionou-se de forma singular e inovadora com a cidade.

A reflexão proposta sobre o espetáculo partiu de alguns materiais bibliográficos coletados, em especial o "Dossiê Bom Retiro: 958 metros - 0 acontecimento: olhares sobre o Vertigem "(2012), uma edição especial da revista Sala Preta, inteiramente dedicada à montagem. Examinaram-se também os relatos de luz escritos pelo iluminador Guilherme Bonfanti ao longo do processo de elaboração do espetáculo ${ }^{10}$ e a tese de doutorado de Elizabeth Néspoli ${ }^{11}$, esta também inteiramente dedicada ao espetáculo, na perspectiva da recepção do publico. Néspoli acompanhou o processo de criação e montagem do espetáculo, além de todo o período em que esteve cartaz, quando realizou sistematicamente entrevistas com os espectadores. Adicionalmente foram realizadas entrevistas informais com integrantes do grupo e que participaram do processo de criação do espetáculo. Conto aqui também com minha própria experiência pessoal enquanto espectadora daquela montagem.

10 Bom Retiro - Relatos de Luz. 2013

< http://guilhermebonfanti.com.br/22/bom-retiro-relatos-da-luz/

11 Teatro da Vertigem: Construção Poética e Recepção. Estudo do campo de tensão que se instaura no encontro da proposição artística com seus receptores. Tese (Doutorado) - Escola de Comunicações e Artes, Universidade de São Paulo, São Paulo, 2015. 
Outra referência bibliográfica importante para amparar a reflexão sobre os procedimentos adotados pelo espetáculo para com a memória do bairro foi o texto "Caminhando pelo passado dos outros" de Gabi Dolff-Bonekämper e que faz parte do livro "Patrimônio Cultural:Memória e Intervenções Urbanas"(2017). Nesse ensaio a autora levanta perguntas relevantes sobre a ideia de identidade local e sobre como é possível estabelecer relação com a memória do outro, e sugere a caminhada como um instrumento valioso para se relacionar com espaço de memória. A prática de derivas foi um recurso bastante usado no processo de criação e muito importante na construção do espetáculo. Nesse sentido algumas questões pertinentes sobre a ideia de trabalhos site-specific foram tocadas, especialmente no que diz respeito à ação da luz sobre o espaço urbano. A extensa pesquisa que Néspoli realizou acerca da recepção do espetáculo demonstra que algumas das operações de intervenção na cidade propostas pelo projeto de luz tiveram grande impacto nos espectadores. De forma que a presente análise priorizará o estudo das cenas que aconteceram na rua e o foco da investigação será o potencial que algumas propostas de intervenção urbana tiveram em de requalificar a experiência com relação à cidade.

\section{Bom Retiro 985m e as derivas ${ }^{12}$}

O espetáculo do Teatro da Vertigem estreou em junho de 2012, quase um ano após as primeiras experiências do grupo no bairro do Bom Retiro, em São Paulo. Foi batizado de "Bom Retiro 985m" em alusão à distância espacial que o publico percorria entre o começo e o fim da performance. Existe um dado sobre a montagem que é relevante para pensar a natureza daquele projeto e que imprimiu uma perspectiva particular frente às produções anteriores do grupo: assinou-se um termo de responsabilidade, com a Prefeitura e a Secretaria de Trânsito da cidade, em que assumia-se a condição de que a cidade não iria parar durante as apresentações, ou seja, que o deslocamento de pedestres e carros não

12 “Derivas são deambulações realizadas no espaço urbano a partir de dispositivos aleatórios, o ideal é que o caminhante se perca, pois o objetivo é a ruptura com percursos automatizados e utilitários, como defendem os criadores do movimento situacionista. Movimento europeu da década de 1960 de crítica à alienação nas sociedades capitalistas ocidentais. Um de seus principais mentores, o escritor francês Guy Debord, autor do livro A Sociedade do Espetáculo, defendeu a prática da deriva como atitude de resistência às cidades-espetáculo que reduzem a participação do corpo físico e dos afetos na construção arquitetônica e na ocupação do espaço urbano." (NÉSPOLI, 2015,p.35) 
seria reorientado e nenhuma via seria interditada. Esse fato tornou-se fundante da vocação do trabalho, e da maneira com que o grupo pretendeu interferir no tecido da cidade, gerando ruídos para espectadores de dentro e fora do espetáculo.

A pesquisa do Teatro da Vertigem no Bom Retiro começou de fato em fevereiro de 2011, a partir de uma residência de três meses na Oficina Cultural Oswald de Andrade, onde se produziam oficinas diárias com duração de cinco horas. Algumas perguntas preliminares sobre a questão do site-specific foram ponto de partida para as experiências propostas nesse período, como por exemplo: qual o papel do site-specific dentro da sociedade de espetáculo? E como pensar um trabalho para a cidade que problematize a lógica da cidade-espetáculo? Nesse sentido o trabalho de campo no bairro foi muito influenciado pela leitura dos textos produzidos pelos situacionistas, com 'A Sociedade do Espetáculo' de Guy Debord configurando um marco fundamental daquelas propostas. Assim, as experiências de deriva no bairro foram uma prática recorrente na primeira fase do trabalho e trouxeram elementos muito interessantes para a pesquisa, que acabaram conduzindo toda a construção dramatúrgica da peça.

Vale registrar que o Teatro da Vertigem lida com a questão do site-specific desde a sua gênese e ao longo de vinte anos de atuação já incorporou diferentes tipos de procedimentos para mapeamento dos seus espaços de investigação. A escolha desses espaços desempenha um papel determinante para o desenvolvimento dos projetos realizados, em que o intuito é aprofundar tanto aspectos da geografia física dos lugares quanto as relações políticas e sociais nas quais estão imbrincados. A questão do deslocamento sempre foi um ponto central das encenações, com o público sempre impulsionado a algum tipo de percurso físico. Nesse sentido é importante destacar que o grupo tem como metodologia de trabalho o que é chamado de processo colaborativo. Desta forma, não se parte de um texto pré-definido e o espetáculo é montado a partir do resultado de pesquisas preliminares e das propostas e provocações que surgem nos ensaios e workshops - cenas criadas a partir de estímulos propostos pela equipe de direção. No caso do Bom Retiro esses ensaios e workshops foram realizados em ruas, lojas, corredores de shoppings, entre outros locais do bairro. Assim, ao longo desse processo de pesquisa todas as áreas de atuação - direção, atores, luz, cenário, dramaturgia - são contaminados umas pelas outras ao longo do processo e o resultado dessas interações se torna material para o espetáculo.

\footnotetext{
“Trata-se de uma situação híbrida em que estética, psicofísica e política se entrelaçam para a reconfiguração do espaço e das relações entre os presentes. 0 Vertigem não faz teatro para espectadores, mas com os presentes (e as presenças). 0 Vertigem não faz teatro no espaço, mas com o
} 
lugar (e suas massas visíveis e invisíveis). Significativamente, o grupo faz teatro para fazer a cidade. E é justamente esse acréscimo relacional em suas múltiplas variantes que permite a passagem da noção de obra teatral para a de evento teatral, ocorrência determinante na aproximação investigada aqui entre performance e teatro." (FABIÃO, 2011, p.247)

No caso do espetáculo "Bom Retiro 985m" as derivas foram uma ferramenta que possibilitou descobertas muito frutíferas e, a partir de dispositivos muito simples, os atores foram se conduzindo pelas mais diversificadas situações. Por exemplo, numa certa situação um ator determinou que só poderia continuar sua caminhada quando escutasse um novo idioma falado. Em outra, um ator se propôs a seguir sacolas de compra, e acabou sendo levado até uma Cracolândia. Em outra deriva a proposta era seguir rastros de lixo abandonado, o que levou o diretor ao encontro de uma montanha de retalhos descartados. As derivas foram realizadas ao longo de diferentes períodos, o que possibilitou a percepção do contraste de movimento no bairro durante o dia e a noite; enquanto de dia havia um intenso deslocamento de pessoas devido a movimentação do comércio, a noite as ruas se transformavam em uma cidade-fantasma.

Como já foi dito, e é da natureza do trabalho desenvolvido pelo grupo, todo material dramatúrgico foi constituído a partir das experiências preliminares e o fio condutor dos espectadores eram personagens fantasmagóricas, que haviam sido construídas durante o processo, a partir dessas derivas. Esse aspecto da experiência de mergulho no Bom Retiro acabou se imprimindo na encenação, de modo que o espectador era colocado diante dessa perspectiva de deambulação em relação ao bairro. As fronteiras entre a arte e a cidade foram diluídas, gerando, eventualmente, até um certo desconforto nos espectadores, pois em alguns momentos os tirava de sua zona de segurança.

Na retirada do ingresso na Oficina Cultural Oswald de Andrade era entregue um mapa do bairro para os espectadores, já indicando o caráter espacial da experiência. 0 espetáculo se iniciava na rua, em frente a um centro comercial, e logo ocupava os corredores internos e lojas deste Shopping. Depois o público ia sendo conduzido pelos muros da estrada de ferro, ruas vazias, lajes e marquises de lojas, até chegar em frente ao ICIB (Instituto Cultural Israelita Brasileiro) o que culminava na entrada do público pelas ruínas do TAIB (Teatro de Arte Israelita Brasileiro). Por fim, a peça se encerrava na calçada em frente ao teatro, a poucos metros do ponto de partida. A experiência desse deslocamento era tão intensa que, ao final, o público, mesmo acompanhado de um mapa, muitas vezes demorava para entender onde estava em relação ao ponto de inicio. Nesse sentido a estratégia da encenação se aproximava bastante do entendimento potencial que Gabi Dolff tem de experiência da caminhada: 
"A caminhada é importante pois é somente por meio dela, por meio da mudança constante de posição e perspectiva, que o espaço de um acontecimento pode ser experimentado em todas as suas dimensões: o procurado e o inesperado, as fachadas e as vistas posteriores, os edifícios e as pessoas, os ritmos e as coreografias da vida cívica de uma cidade." (DOLFF- BONAKÄMPER, 2014, p.69)

\section{Ação da Luz}

O desafio de lidar com a dispersão da cidade colocou-se desde o inicio do processo como um ponto central de reflexão e está descrito em vários trechos dos relatos de Bonfanti ao longo do processo de trabalho. Existe de início a vontade de recusar o uso dos equipamentos tradicionais de iluminação e também a intenção de entender qual o papel que a luz deveria ter no contexto urbano. Néspoli destaca que durante a etapa de workshops, e até mesmo já na fase de ensaios, a iluminação colocava-se como um problema para os atores, já que muitas cenas realizadas na penumbra das ruas mal podiam ser vistas. (NESPOLI, 2015, p.124). Foram experimentados seguidores de luz com bateria, mas a ideia de um foco fugia da proposta que a pesquisa intencionava, e nesse sentido pensou-se em usar placas led para iluminar a cena, o que foi logo descartado. Nos relatos do processo é nítida a vontade de Bonfanti de explorar climas e dramaticidade próprias da iluminação publica, e nesse sentido foram experimentados para direcionamento do público recursos utilizados para sinalização de transito, desde setas e baldes de luz, até o uso das cores verde, vermelho e amarelo.

\footnotetext{
"Outra questão interessante a observar é a ideia de seguidores com bateria. Gosto da ideia mas não da forma, o foco redondo. Acho importante destacar o ator da paisagem, mas não sei se o tempo todo. Fica uma impressão de que o cracômano deveria estar na luz da cidade, mas ao mesmo tempo a luz chama a atenção do público e direciona o olhar, mas gostaria de entender mais isso. (...) Rua, um dos maiores problemas a serem resolvidos. Como criar uma luz que interfira na cena? É preciso ter uma luz que interfira na cena? Como se utilizar da cidade intencionalmente?" (BONFANTI,2013,p.12)
}

Diante na natureza do espetáculo essa questão estava implicada de maneira ainda mais direta na encenação: de que forma as personagens deveriam permear o tecido urbano? Desde o principio do processo havia a intenção de se intervir nos postes de iluminação 
pública, e essa sempre foi uma chave importante para o projeto de luz. Existia uma qualidade fantasmagórica na montagem que foi construída muito a partir da experiência de deslocamento naquelas ruas que a noite se encontravam desertas; sendo os postes com vapor de sódio um elemento bastante relevante para essa atmosfera. Várias soluções foram pensadas e após muitos esforços foi desenvolvida uma traquitana que atuava mecanicamente sobre a luz dos postes, e que foi instalada em cerca de 20 dos 27 postes que se encontravam ao longo percurso. É importante ressaltar que essa solução foi resultado de um longo processo que contou com inúmeras dificuldades burocráticas até que as traquitanas pudessem, com ajuda do órgão responsável pela iluminação publica da cidade, serem instaladas.

\begin{abstract}
"O Tó achou a traquitana e o black-out da rua bastante potentes, fechar as luzes da rua é uma experiência não vivida pelas pessoas, e o movimento de se perder a luz tem uma boa dramaticidade. Repetindo os movimentos também observamos que dependendo de como for feita a cúpula, é possível criar focos de luz - tal qual limitar um PC com cinefoil. Acredito que o movimento de operação e roteiro de luz na rua seja mais interessante no caminho de ter a luz urbana tal qual ela é, e ir se modificando para acontecer a cena - mais do que dar black-out na rua e ir iluminando-se apenas onde deseja, tal qual uma luz de teatro convencional."
\end{abstract} (BONFANTI,2013,p.41)

As traquitanas funcionavam ora apagando a luz, ora colorindo, ora recortando o facho tal como um refletor de teatro; além disso eram acionadas por operadores de luz que, uniformizados, manipulavam estas diante dos espectadores com auxilio de bastões. Esse tipo de interferência nos postes de iluminação pública se mostrou extremamente eficaz para a condução do espetáculo; mesmo sendo uma ação conceitualmente simples, era monumental na maneira como alterava profundamente a relação espacial com a rua e a cidade. Ruas inteiras foram apagadas e coloridas e isso gerou um efeito dramático extremamente potente, e o fato de que a manipulação dos contrarregras acontecia de maneira explicita ao público e no aqui e agora, também teve um enorme impacto na recepção do espetáculo. Néspoli destaca que a intervenção nos postes de luz foi, possivelmente, o elemento mais sublinhado dos procedimentos criativos do espetáculo nos depoimentos recolhidos. Na análise da pesquisadora, apropriar-se da iluminação pública sem fazer disso um ato privatizador, mas sim aberto ao compartilhamento de todos, público pagante e agregados ao cortejo, produziu por si só um efeito crítico que pode ser percebido nas produções de sentido detectados na recepção. (NESPOLI, 2015,p.152). 
Seguem abaixo alguns depoimentos escolhidos da tese citada (grifos meus):

"Foi a sensação geral que me agradou mais, penso, e da qual me dei conta mais claramente quando andávamos por aquela rua da cena dos catadores de papel, em que de repente a gente se vê no meio de uma 'tomada' da cidade, com o ator dos atentados trazendo um manequim em chamas, outro transando com um manequim, pessoas correndo, cantando, um homem com cabeça de camelo tocando sax e saindo de um estacionamento - e as lâmpadas da rua sendo cobertas e descobertas... Parecia a 'parada de carnaval do fim do mundo'; foi o momento em que mais senti a intervenção na cidade."

(37 anos, mestrado em artes cênicas, professora de teatro) p.122

"Eu imaginei que iríamos andar nas ruas, mas não imaginei que os atores teriam "a chave da cidade". Pois foi o que pareceu pra mim. Que eles tinham a chave da cidade."”

(39 anos, aluna do curso de Direito da UNIESP, supervisora jurídica) p. 125

“(...)Numa apreciação técnica, era surpreendente ver que postes comuns eram reorganizados em iluminações cênicas, através de uma complexidade notável. Havia, claro, um apreço técnico, mas acima disso, a certeza de que a cidade é nossa, é feita por nós, é orgânica por nós, então aquilo não era absurdo. É uma necessidade de releitura, redescoberta de ações possíveis, ressignificações. Apropriar-se do espaço do qual nos perdemos, ele estará ali de qualquer forma, para a nossa fuga, a nossa indiferença, ou as nossas artes e afetos.

(psicólogo, 25 anos, mestre em psicologia social com pesquisa sobre urbanidade) p.151

"Sinceramente, eu fiquei maravilhado com os jogos de luzes e efeitos que foram produzidos ao longo do espetáculo. Achei impressionante os cenários improvisados, os sons, o inesperado. Nada de fora me tirou a atenção. Eu não queria que acabasse. Parecia que eu estava observando meu próprio sonho."

(escrevente de justiça, foi ver por recomendação da juíza com quem trabalha) p.167 
"Quando você pediu para escolher um aspecto acabei passando a peça toda pensando em qual seria o principal aspecto é o velho problema que a filosofia tenta resolver: que quando estamos fazendo a pergunta, já estamos endereçando a resposta. Eu achei ela toda maravilhosa, mas talvez o principal aspecto foram os contrarregras fazendo a cidade atuar. E talvez a frase que mais simbolize isso é da consumidora perdida (na Ribeiro de Lima e Aimorés) perguntando se "mudaram os sentidos das ruas". Antes de começar a peça imaginava se haveria a polícia ou CET fechando as ruas por onde a peça passaria, até perceber que estávamos mesmo em uma rua de um único propósito (e sentido). (...)

(homem, formação em filosofia) p.186

"O efeito da luz que se apaga sobre o muro do viciado, como um eclipse, foi deslumbrante - não só porque me surpreendeu como porque o efeito se desvelava diante dos nossos olhos (e era incrível ver essa maquinaria tão artesanal e tão delicada)". (professora e pesquisadora de artes cênicas da UNIRIO) p.190

"O que também ganhou minha atenção foi a produção do espetáculo. A hora que a luz da rua "apagou" e vi que era uma traquitana genial da companhia para cobrir a lâmpada, o carrinho com a caixa de som, os homens com os projetores, os lugares escolhidos. Achei tudo muito bem pensado e executado.(...)"

(mulher, jovem estudante no Instituto Criar) p.190

"Vestidos com lindos macacões de lycra do Marcelo Sommer, os atores, porque não posso chamá-los só de técnicos ou operadores, que manipulam a luz, o vídeo e o áudio do espetáculo são um grande TIME de pessoas que só podem ser apaixonadas pelo que fazem, que querem estar ali, que dão o sangue por aquele trabalho que, assim como os atores, acreditam ser aquela obra a mais urgente para o momento que passam(...) Na rua, tudo é sonho. Por gambiarras incríveis, eles manipulam as luzes dos postes de luz da própria rua - com gelatina coloridas ou cinefólio, fazem as luzes da rua piscarem, se apagarem ou diminuírem de intensidade. Não é teatro de rua....é o teatro na rua, com todo o seu aparato técnico que uma caixa preta permite!!!!! (...)” (aluno de pós-graduação em artes cênicas da UNIRIO, enviado aos colegas no dia 12/10/2012) p.191 
"Na esquina onde houve a briga das mulheres (logo após a briga), a iluminação da rua foi tampada e a Noiva apareceu numa marquise. As projeções eram em tom de azul, mas o público, no meio da rua, ganhava tons de vermelho e de verde, do farol para pedestres, que estava bem embaixo dela. Me peguei olhando aquela alternância de cores sobre as pessoas - uma iluminação do dia-a-dia que não costumamos reparar, e fiquei encantada com o efeito que produzia (eu estava na calçada do lado oposto ao da cena, a luz não me alcançava, mas por isso via bem essa iluminação). Fiquei me perguntando o quanto esse efeito havia sido planejado pelo diretor ou iluminador."

(atriz, professora de teatro, mestre em artes cênicas pela ECA/ USP) p.194

"Vários momentos eu percebia a rua "se intrometer" na cena e isso era ótimo. Quando estávamos na rua vendo aquele desfile os sinais de trânsito verde e vermelho para o pedestre pareciam jogar com o movimento dos atores na passarela. Alguns momentos as cores dos sinais iluminavam os espectadores e nos lembravam que tudo aquilo acontecia embrulhado pelas ruas da cidade. (...)"

(pesquisadora, 44 anos) p.194 

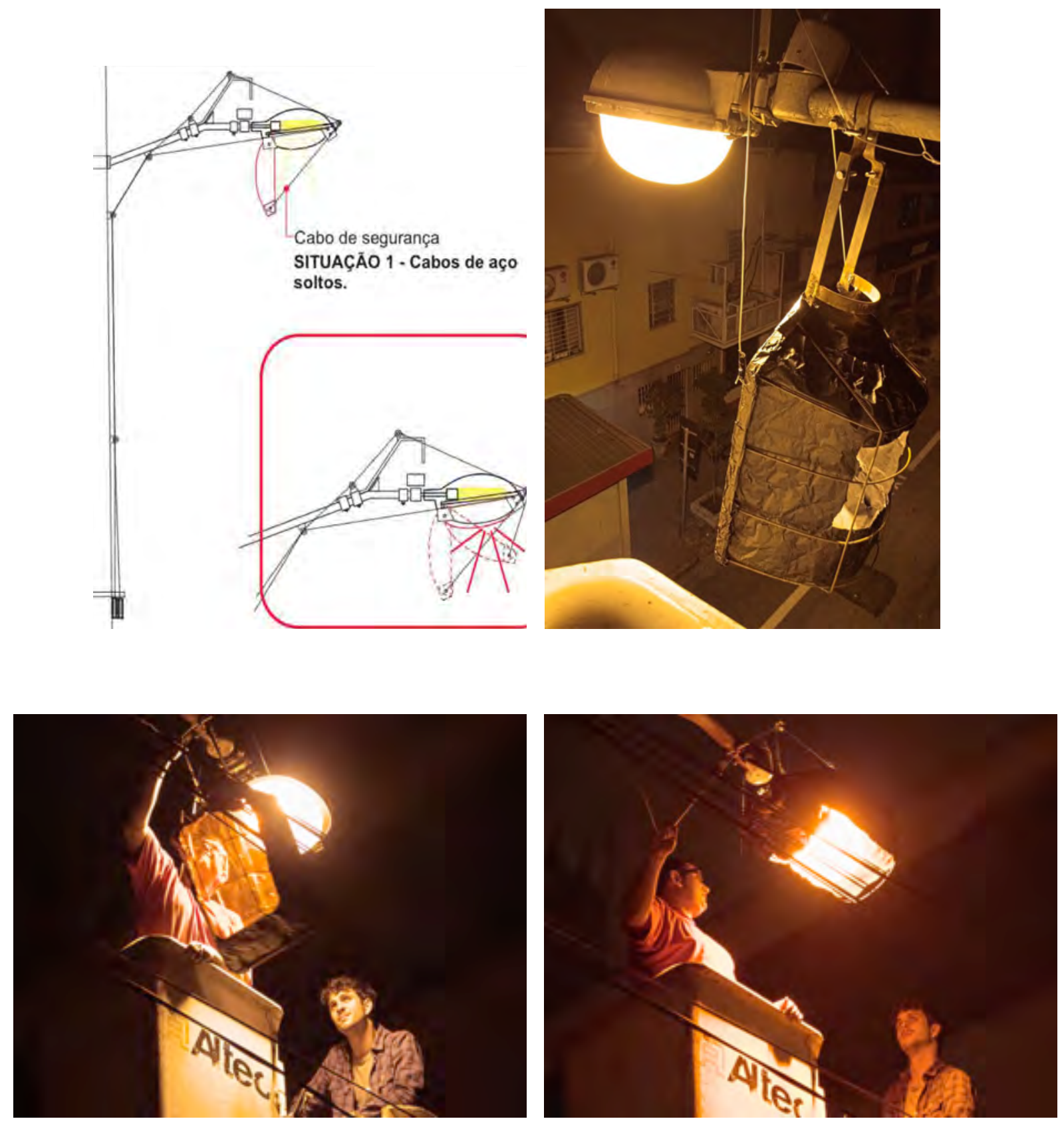

Desenho técnico do projeto e registro da instalação das Traquitanas

FONTE: Teatro da Vertigem 
Mesmo existindo um núcleo ficcional que funciona como dispositivo para a ativação do espaço urbano é possível perceber por esses relatos que a operação dos dispositivos de iluminação pública atuaram no sentido de alterar a percepção sensível daquele espaço urbano e tiveram um enorme impacto na recepção e produção de sentido do espetáculo. Existe um caráter de epifania no ato de se apagar uma rua inteira a partir da operação de dispositivos muito simples articulados por um grupo de pessoas. Como a espectadora entrevistada por Néspoli diz: "é ter a chave da cidade nas mãos".

A hipótese aqui levantada é a de que o projeto de iluminação desenvolvido por Guilherme Bonfanti conseguiu penetrar no tecido da cidade e com isso conduzir o publico pelo percurso proposto de maneira sutil, mas muito precisa, e colocando-se como parte fundamental para o sucesso da proposta de encenação do espetáculo. Pode se dizer, com os relatos, que as traquitanas funcionam como agentes capazes de reorganizar a experiência do cotidiano, reposicionando os espectadores em relação ao espaço público da cidade e acionando a capacidade imaginativa de atuação no espaço. A ação abarca o entendimento que Lefebvre faz do potencial transformador que o espaço urbano tem para com a cotidianidade.

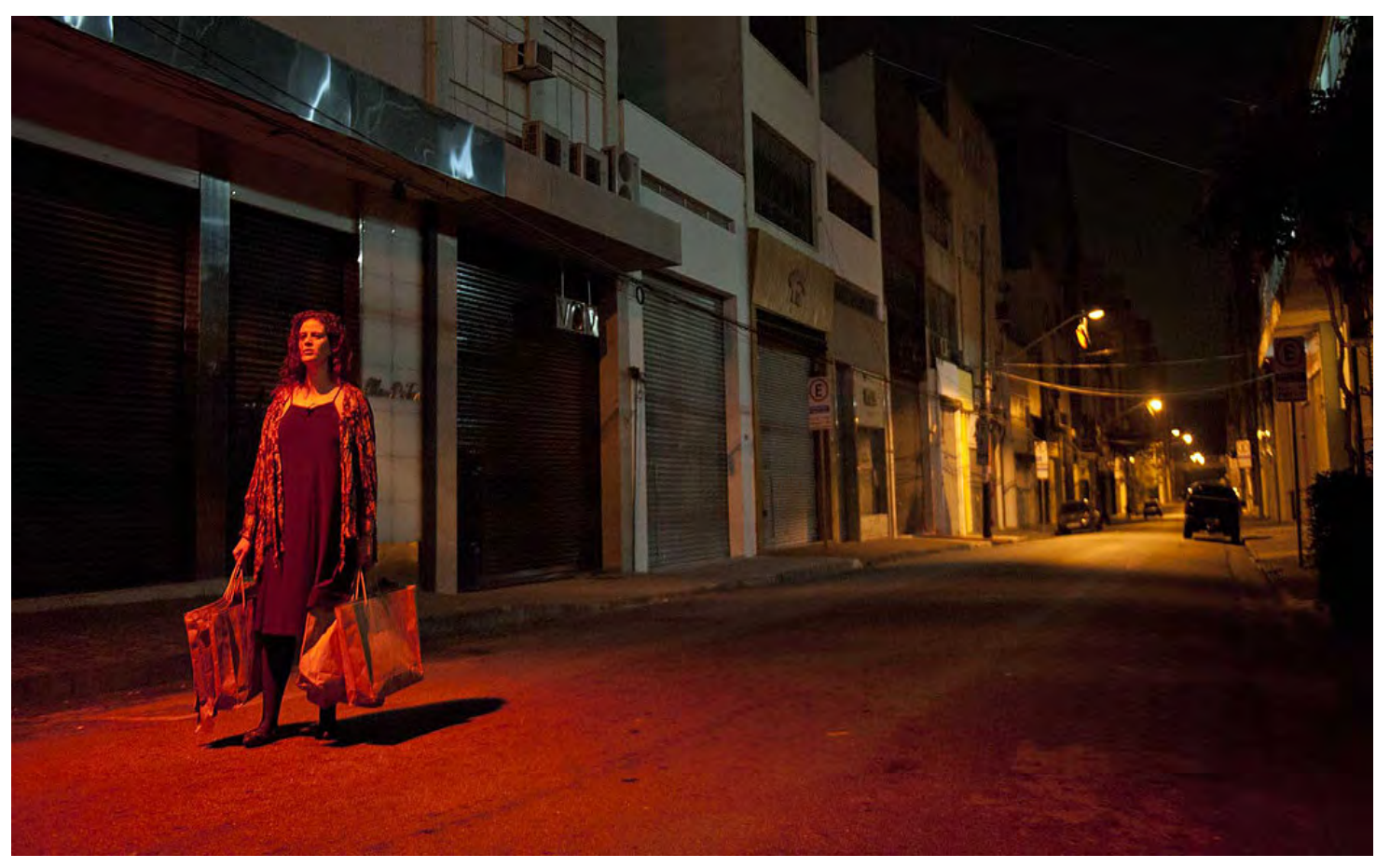

Traquitanas em funcionamento nos ensaios do espetáculo "Bom Retiro 985m" FONTE: Teatro da Vertigem 
"A menor mudança da vida cotidiana parece impossível. Pôr em questão seja o que for que concerne à cotidianidade é grave inquietante. (...) 0 que é que isso prova? Que a cotidianidade inteira deve ser questionada. (...) Para que reencontre a qualidade e as propriedades do ser humano, é preciso que supere o cotidiano, dentro do cotidiano, a partir da cotidianidade!" (LEFEBVRE, 1968, p.204)

\section{O TAIB}

Como já foi dito a forma como a operação de luz foi proposta por Bonfanti revelou-se extremamente eficaz na condução dos espectadores, criando imagens muito poderosas ao longo do percurso e estabelecendo de uma maneira bastante intensa a penetração do espetáculo no tecido da cidade. Talvez um dos momentos de ápice do espetáculo tenha sido a chegada do público à fachada do prédio do ICIB, que é seguida pela entrada na parte interior do TAIB. Nesse momento, todos os postes da rua eram apagados e lentamente uma luz púrpura acendia-se para o solilóquio da Noiva - personagem que ao longo da trama dialogava com as questões de memória daqueles espaços. Ao mesmo tempo surgia uma projeção mapeada de um motor propulsor de foguete em referencia à utopia da Casa do Futuro (Dibuktronik), que orientou à construção daquele espaço cultural. A personagem realizava um suicídio simbólico jogando seu longo véu pela janela com pisca-luzes em referencia aos judeus mortos pela guerra e que foram homenageados com a construção daquele edifício. Em seguida todo o prédio se acendia por dentro gerando uma imagem bastante poderosa, para quem assistia a cena de fora, que remontava à historia daquele edifício e trazia à tona uma memoria moribunda.

\footnotetext{
"Neste crescendo, chega-se ao Teatro de Arte Israelita Brasileiro (Taib), signo de importância histórica, política e cultural não só do bairro, mas da própria cidade, e que há anos encontra-se morto, abandonado. Deparar-se por um instante com toda sua ampla fachada em vidro iluminada, em contraste com seus arredores, revelou como num lampejo a chance e o desejo de sua ressurreição. E em nome dessa possibilidade, '958 metros' ingressa em seu interior, vivificando seus espaços gélidos, danificados e depauperados. Nesse entremeio, e sem saber nada ao certo, vemonos imersos numa rede de ambiguidades entre a vida e a morte, ilusão e realidade, existência e ausência, fé e descrédito, esperança e desalento" (PALLAMIN, 2015,p.190)
} 


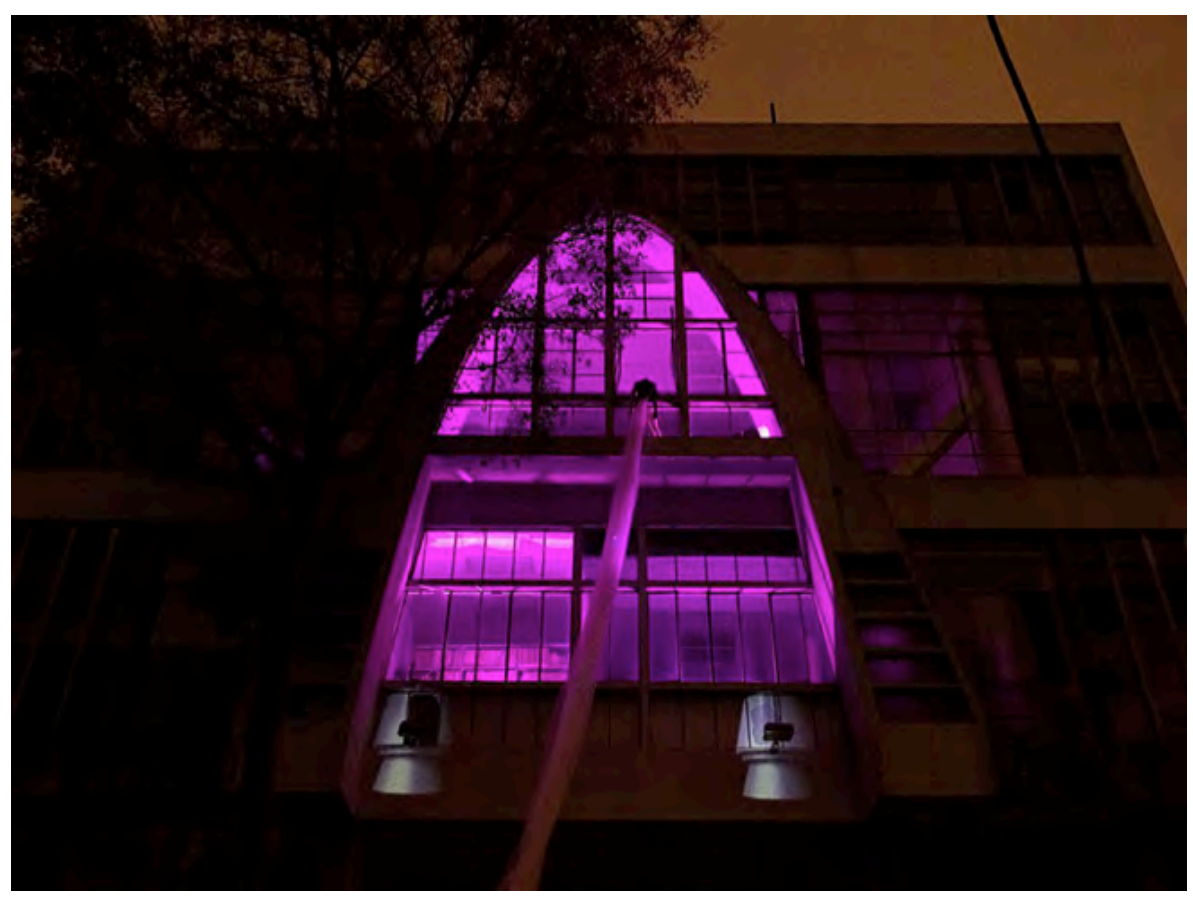

O Dibuktronik, espetáculo “Bom Retiro 985m”, 2012, São Paulo. FONTE: Teatro da Vertigem

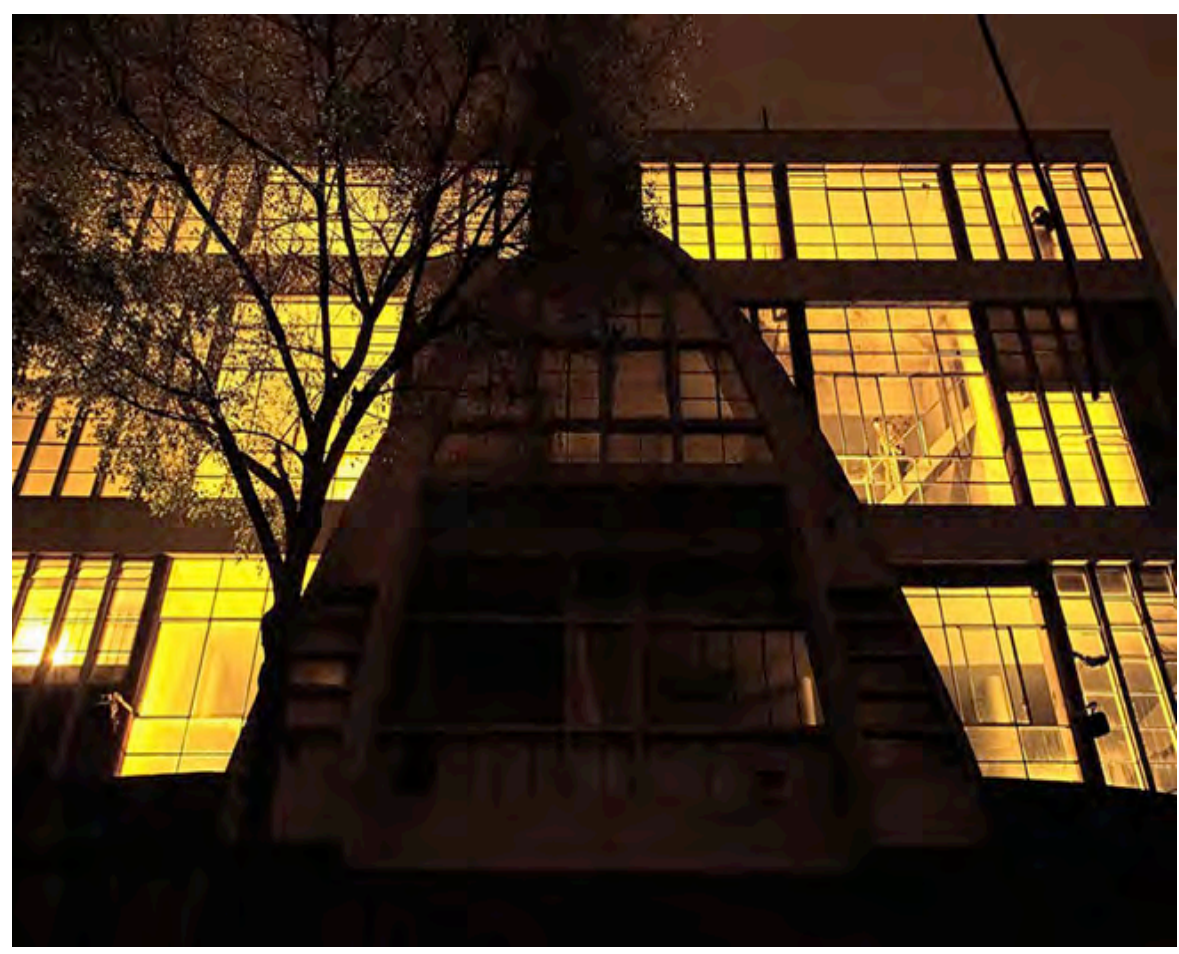

Noiva: decolagem, espetáculo “Bom Retiro 985m”, 2012, São Paulo. FONTE: Teatro da Vertigem 


\section{A gambiarra como elemento potencial}

A linguagem desenvolvida por Bonfanti ao longo desses quase vinte anos de atuação com o Teatro da Vertigem em processos colaborativos e site-specific, foi construída em torno da apropriação dos mais diversos elementos cênicos e na subversão do uso dos equipamentos tradicionais para a criação da luz. Ou seja, uma linguagem estabelecida a partir de uma lógica da gambiarra, no melhor sentido do termo. No caso de "Bom Retiro 985m" essa mesma lógica está presente. No entanto, a partir do momento que o espetáculo tem que lidar com a dimensão da rua, novos elementos são inseridos na pesquisa. É interessante como algumas imagens criadas pelo projeto de luz ao longo do percurso do espetáculo pelas ruas do bairro conseguem ser monumentais - no sentido de gerarem enorme impacto na recepção - porém sem tenderem para o espetacular - no pior sentido do termo - o que estaria associado ao uso de artifícios para o entretenimento do público, porém sem uma dimensão crítica e uma profundidade estética.

Em uma passagem de seus relatos o iluminador refere-se à ideia de intervir com filtros de cor nos postes e ressalta que a intenção não é colorir por colorir, e sim colorir a partir de um conceito que está relacionado ao personagem. De forma que as intervenções e a forma como são operadas as traquitanas estão profundamente intrincadas no núcleo ficcional do espetáculo. E por acontecerem de forma tão mimetizada com o tecido da cidade existe uma suavidade na maneira como essas imagens vão sendo formadas. Ao mesmo tempo, existe um impacto gerado pela ação dos postes na recepção, como observado nos depoimentos citados acima, que parece ter sido causado pela carga poética que a própria traquitana carrega. A hipótese aqui levantada vai no sentido de que existe uma qualidade artesanal na maneira como foi elaborada e com que é operada, que confere um ar mágico para as traquitanas.

Com todo o arsenal tecnológico disponível hoje para a iluminação de espetáculos e eventos, as vezes cria-se a sensação de que são tantas as ferramentas disponíveis que o espetacular, o monumental, é banalizado. Me parece que muito da dimensão que a traquitana assume na montagem se dá pela forma como ela foi construída e pela simplicidade; se a rua fosse inteira tingida de uma cor, mas sem a força de sua operacionalização, possivelmente o impacto na recepção não fosse o mesmo. Existe uma qualidade artesanal no caso das traquitanas que imprime um potencial conectivo entre as ações e o público. De forma que funcionam com uma lógica diferente da espetacular, e o 'precário' dá vazão para um canal de conexão com as pessoas. 
"Relutei durante muito tempo a usar seguidores, refletores ou algo parecido. Toda a minha observação da rua sempre me fez acreditar que a luz estava ali, era a luz urbana, da cidade, o espetáculo acontece na rua e ocupa a cidade não podemos ignorar isso. Temos na luz urbana do Bom Retiro uma atmosfera fantasmática, os focos amarelos e os intervalos escuros tem uma forte dramaticidade e sempre esperei que isso me daria o que precisava. 0 uso das traquitanas me faz intervir na luz urbana, resignificar sua função, seu uso. Os postes passam a ser minha fonte luz, meus refletores." (BONFANTI,2013,pág.59)

Partindo das experiências citadas nesse capítulo, suas formas de operar e se relacionar com o espaço urbano e tendo como pano de fundo o entendimento - apresentado na primeira parte da dissertação - da performatividade da cor e da luz, a idéia é que o próximo capítulo possa problematizar as questões apresentadas a partir de determinadas intervenções que compõe a minha trajetória como artista. E principalmente por meio de um projeto desenvolvido para o bairro do Bixiga. 


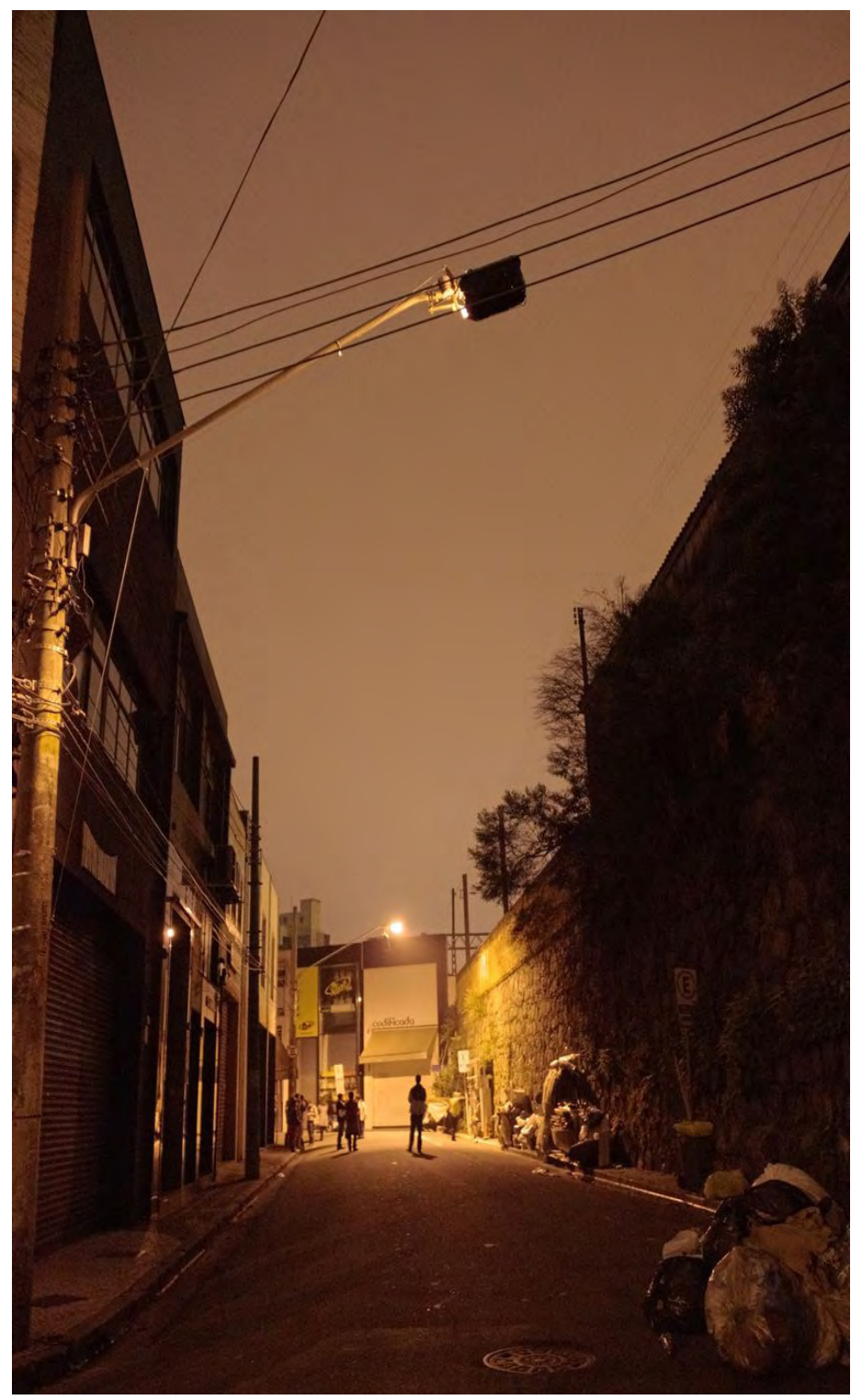

Traquitanas em funcionamento nos ensaios do espetáculo "Bom Retiro 985m"

FONTE: Teatro da Vertigem 
AÇÃO 


\section{PARTE 3: AÇÃO}

A motivação para essa dissertação partiu do desejo de revisitar uma série de intervenções realizadas por mim na cidade de São Paulo, no período de 2005 à 2009. No inicio da elaboração do projeto uma distância de dez anos me separava da primeira intervenção realizada e havia a vontade de retomar esta pesquisa de intervenções com cor na cidade a partir de novos parâmetros. Durante o período em que não estive realizando ações deliberadas na cidade, me dediquei a alguns projetos que não puderam ser viabilizados e também à minha carreira profissional como iluminadora cênica e docente. Trabalhei como iluminadora em companhias como Teatro Oficina, Teatro de Narradores, Companhia Antônima, entre outras.

De toda forma, a intenção dessa investigação é partir do aparato de pesquisa e das reflexões apresentadas nos capítulos anteriores para requalificar essas intervenções passadas e propor um novo projeto interventivo para a cidade. Segue-se, imediatamente, uma breve apresentação dos trabalhos e, mais à frente, tentarei à frente estabelecer ligações com os capítulos anteriores a partir de uma proposta de intervenção a ser realizada no bairro do Bexiga.

\subsection{BREVE GENEALOGIA}

\section{Obra}

A primeira intervenção dessa série foi proposta para um canteiro de grama localizado entre o jardim de esculturas do antigo MAC/USP e a reitoria da Universidade de São Paulo. 0 trabalho consistia em interditar esse canteiro, cercando-o com o mesmo tipo de sinalização usada nas vias públicas para obras de trânsito: cercas de plástico laranja e baldes vermelhos com lâmpadas incandescentes. Na época da execução do trabalho, São Paulo estava toda tomada por obras públicas e a população, muito familiarizada com este índice visual. 0 canteiro escolhido possuía dimensões muito específicas: ele era extenso em sua largura mas bem pouco profundo - possuía aproximadamente $40 \mathrm{~cm}$ de profundidade - o que criava uma estranheza já que não fazia sentido que uma obra de fato se desse naquelas condições. Existia um desejo de mimetizar as obras de trânsito que estavam espalhadas por diversos pontos da cidade e trazê-las para outro contexto. Havia uma hipótese de que a intervenção não seria percebida pela população transeunte do lugar, e de fato não foi. Após a montagem do trabalho, a diretoria do MAC e a Prefeitura Universitária demoraram dez dias para se darem conta de que não se tratava se uma obra de verdade e tomarem providências. 

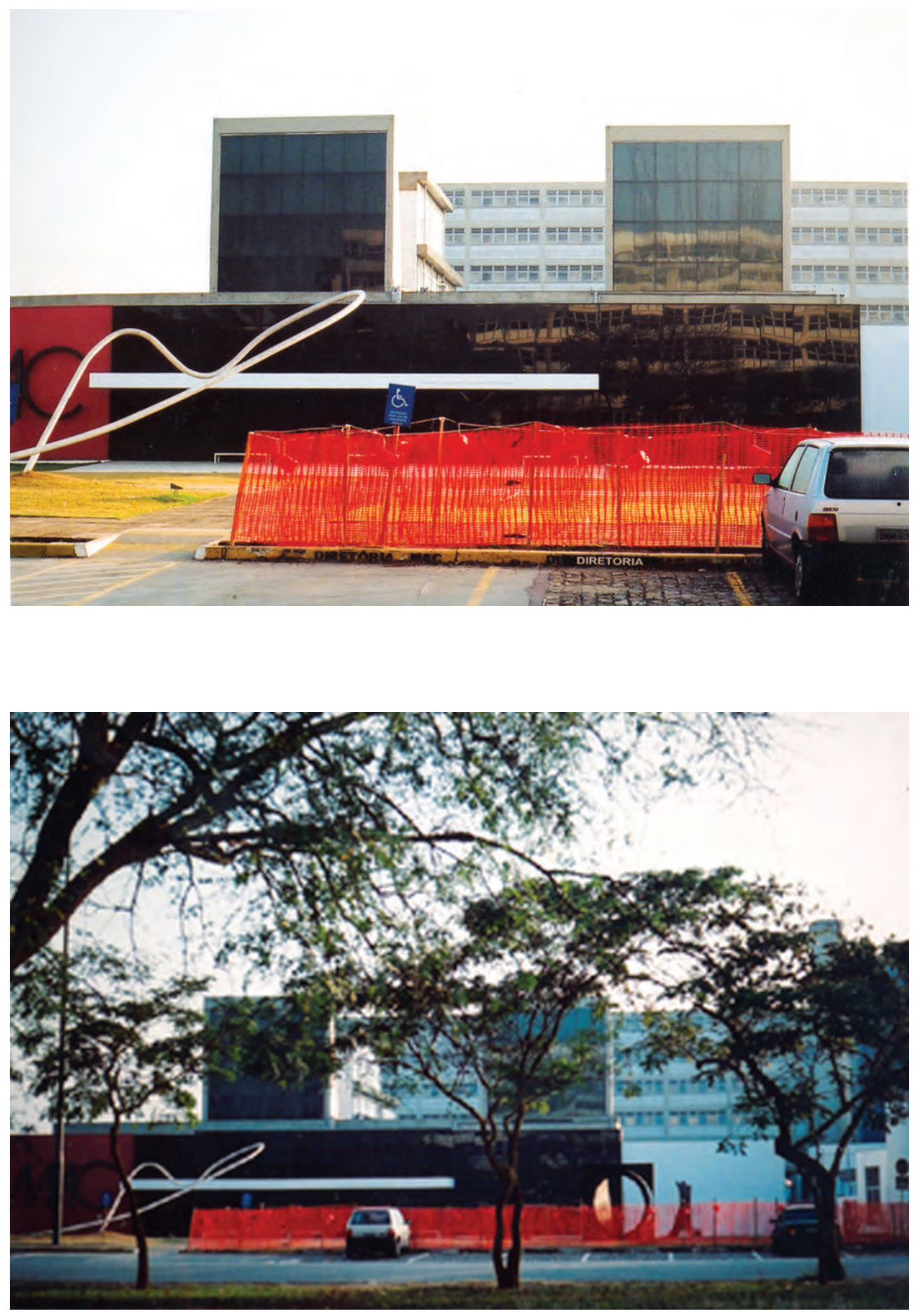

Lúcia Galvão, “obra”,2005.

Fotos: Laila Terra 

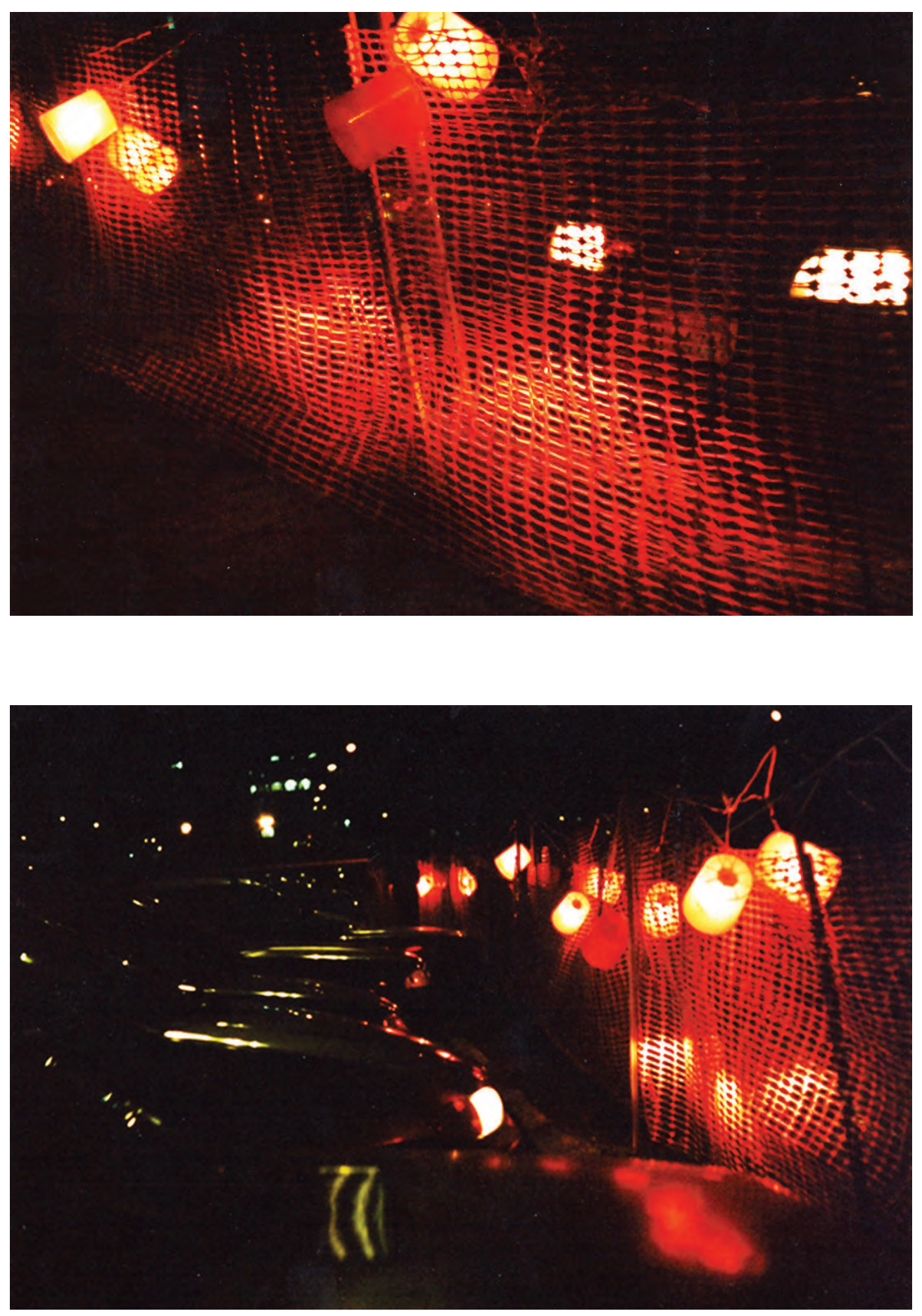

Lúcia Galvão, “obra”,2005.

Fotos: Laila Terra 


\section{O homoerotismo no modernismo brasileiro}

0 segundo estudo de caso foi a intervenção realizada em 2005 no Monumento às Bandeiras. Realizado por Victor Brecheret, o monumento é um cartão postal da cidade de São Paulo, tanto pelo que representa no movimento modernista brasileiro, quando pela simbologia em torno dos bandeirantes. 0 trabalho de intervenção no Monumento consistiu na instalação de gelatinas (filtros) cor-de-rosa nos refletores que iluminam o mesmo. Uma ação preliminar aconteceu nos três dias que antecederam a intervenção: foram distribuídos, nos semáforos de transito situados em torno do local, panfletos impressos em papel cor-de-rosa que continham uma colagem de imagens do monumento, a data de realização e o título do trabalho: "O homoerotismo no modernismo brasileiro".

Foram desenvolvidas caixinhas-traquitanas com as gelatinas, estas podiam ser dobradas e guardadas em sacolas e eram simplesmente encaixadas nos refletores, o que facilitou e agilizou muito a montagem do trabalho. Dentre diversos pontos de interesse que o Monumento possui, está sua localização estratégica - posicionado entre a Assembleia Legislativa, a Academia Militar do Exército e o Parque do Ibirapuera - em um bairro nobre da cidade. Optei por montar o trabalho em um domingo, dia em que há bastante movimento no local devido ao grande número de pessoas que frequentam o parque e seus museus. O horário escolhido foi o crepúsculo e logo que anoiteceu o Monumento estava tingido por um rosa profundo encarnado em sua materialidade.

A obra de Brecheret é uma ode às Bandeiras, apresentando os bandeirantes como heróis da nação. A possibilidade de subverter a relação das pessoas com o Monumento criando uma atmosfera erótica foi uma maneira de abordar com ironia o contexto no qual a escultura se insere. A intenção dos panfletos foi a de divulgar e pré-estabelecer o universo imaginário do trabalho entre os transeuntes do local antes que a instalação fosse realizada. Os filtros permaneceram por mais ou menos 52 horas sem alterações e foi a chuva que lavou e retirou aos poucos as gelatinas, depois restando capengas lá por mais alguns dias.

A escolha do rosa se relacionou a uma série de aspectos simbólicos relacionados a cor - tais como a sensibilidade e afetividade - que foram utilizados nesse caso com intuito de subverter o que seriam as características comumente associadas à figura dos bandeirantes, como por exemplo a virilidade. Nesse sentido a intenção dos panfletos era também de construir essa outra camada subjetiva acerca da escolha da cor, direcionando o espectador e a leitura da ação para as características implícitas no título: "O homoerotismo no modernismo brasileiro". De maneira que a escolha da cor faz parte da essência do trabalho e dos conteúdos simbólicos aos quais ele remete, assumindo um papel dramático. 0 trabalho seria totalmente diferente se houvesse uma outra escolha de cor. 

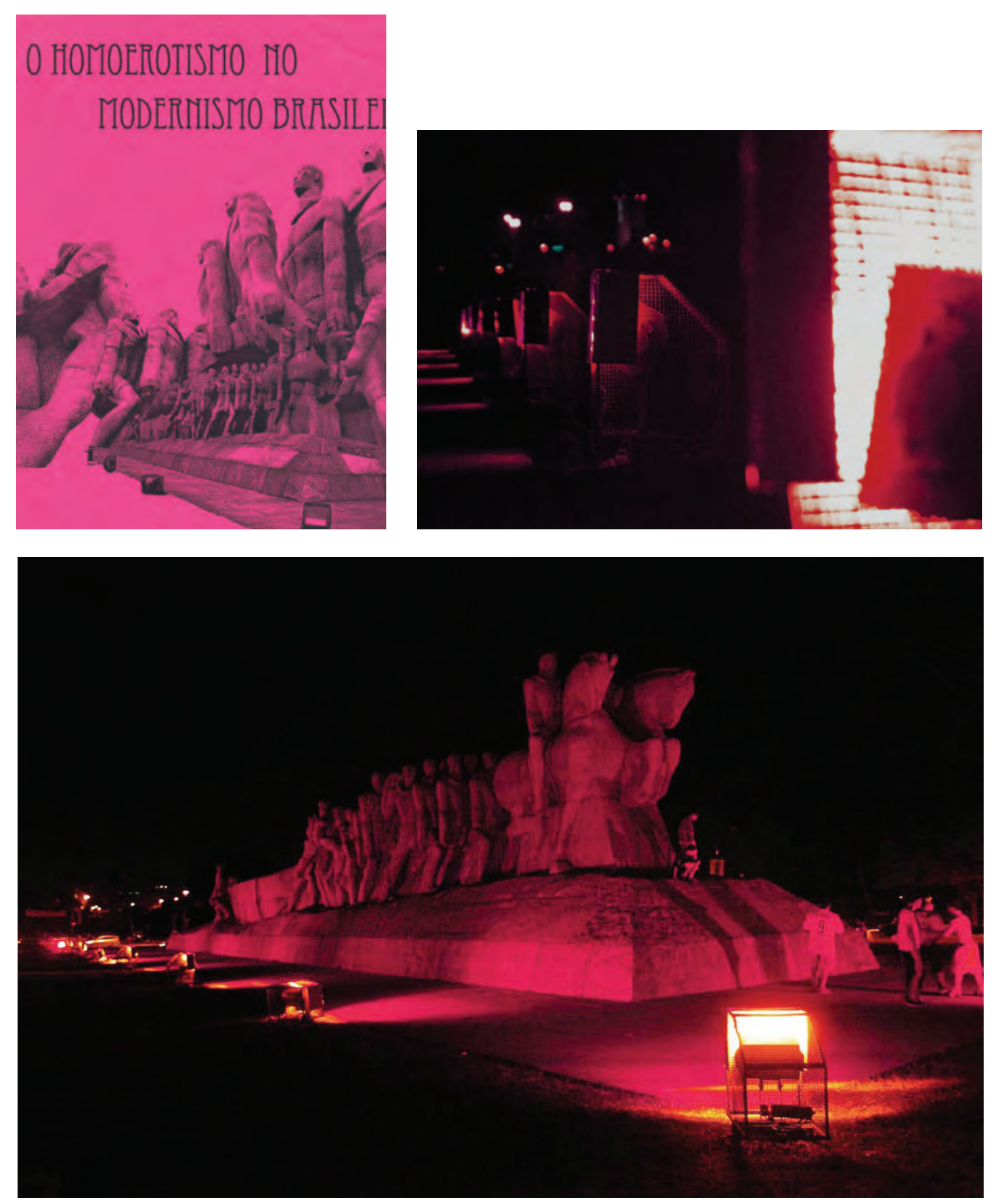

Lúcia Galvão,“o homoerotismo no modernismo brasileiro”, 2005.

Foto: Emiliano Capozoli 


\section{Sem título}

O próximo trabalho a ser apresentado consistiu em intervenções nas caixas de luz (backlights) dos pontos de ônibus localizados ao longo de mais de $3 \mathrm{~km}$ de um importante corredor de ônibus da cidade de São Paulo: a Av. Francisco Matarazzo. 0 trajeto incluído no projeto se estendia por toda a Av. Francisco Matarazzo, passando por baixo do viaduto do Minhocão até o começo da Av. São João, ligando assim cerca de 18 pontos de ônibus. Esse tipo de backlight é geralmente utilizado como base de propaganda publicitária mas nestes pontos de ônibus específicos não havia nenhum tipo de publicidade. Tratavam-se simplesmente de caixas de lâmpadas florescentes brancas cobertas por chapas de acrílico transparentes.

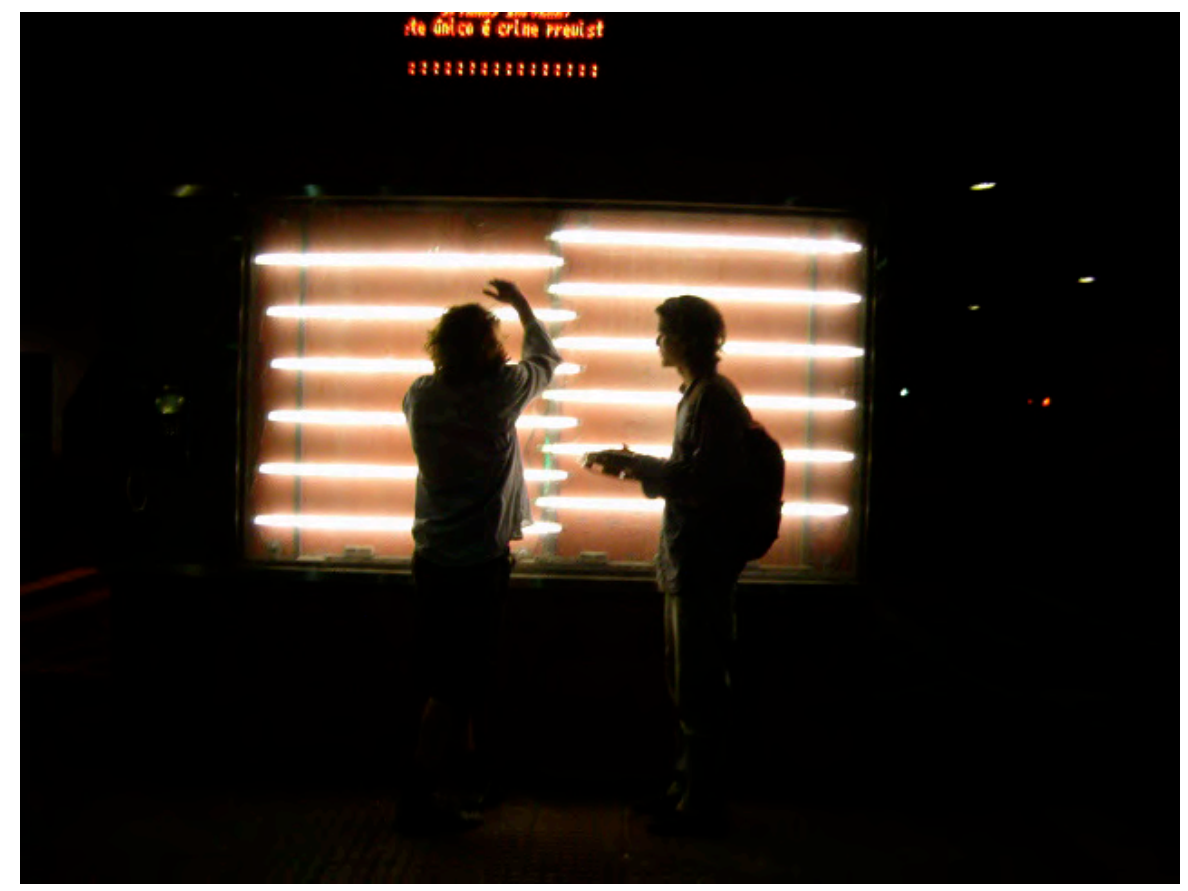

estudos para a intervenção Foto: da artista.

Desde que esses objetos de luz, com as lâmpadas à mostra, começaram a chamar o meu interesse, passaram-se pelo menos seis meses até que eu conseguisse definir o caráter da intervenção. A operação ocorreu em duas etapas e só foi interrompida pela retirada das lâmpadas dos backlights pelo poder público. Ambas as etapas partiram do mesmo princípio: aplicação de folhas de papel de seda nas chapas de acrílico usando goma de lambe-lambe. Devido a extensão geográfica da intervenção fez se necessário contar com a 
colaboração de um coletivo e definir algumas estratégias táticas que nos permitissem dar conta de todo o percurso com alguma rapidez.

Na primeira etapa foi utilizado somente papel de seda azul sem qualquer tipo de desenho. A intenção era produzir um campo de cor, trazer uma estranheza e tentar subverter a relação das pessoas com as caixas, criando uma narrativa cromática para passageiros e motoristas ao longo do corredor. Desde o começo a questão do movimento era fundamental para a apreensão do trabalho, a escolha dos pontos onde as caixas se encontravam estava intimamente relacionada aos corredores de ônibus nos quais estavam inseridos, e o trabalho só acontecia plenamente a partir do deslocamento ao longo das duas avenidas. Nesse sentido me parece que a experiência tinha a intenção de acessar também as camadas imaginativas da percepção cromática. A intervenção tinha caráter bastante efêmero, já que o papel de seda é um material extremamente sensível e que se desfaz muito facilmente; especialmente na segunda etapa, por conta de uma forte chuva, a aplicação permaneceu por algumas horas somente. No entanto pela estranheza que implicava na paisagem, tinha o potencial de despertar a percepção dos sujeitos, especialmente os passageiros de ônibus, para o potencial lúdico e imaginativo da cor.

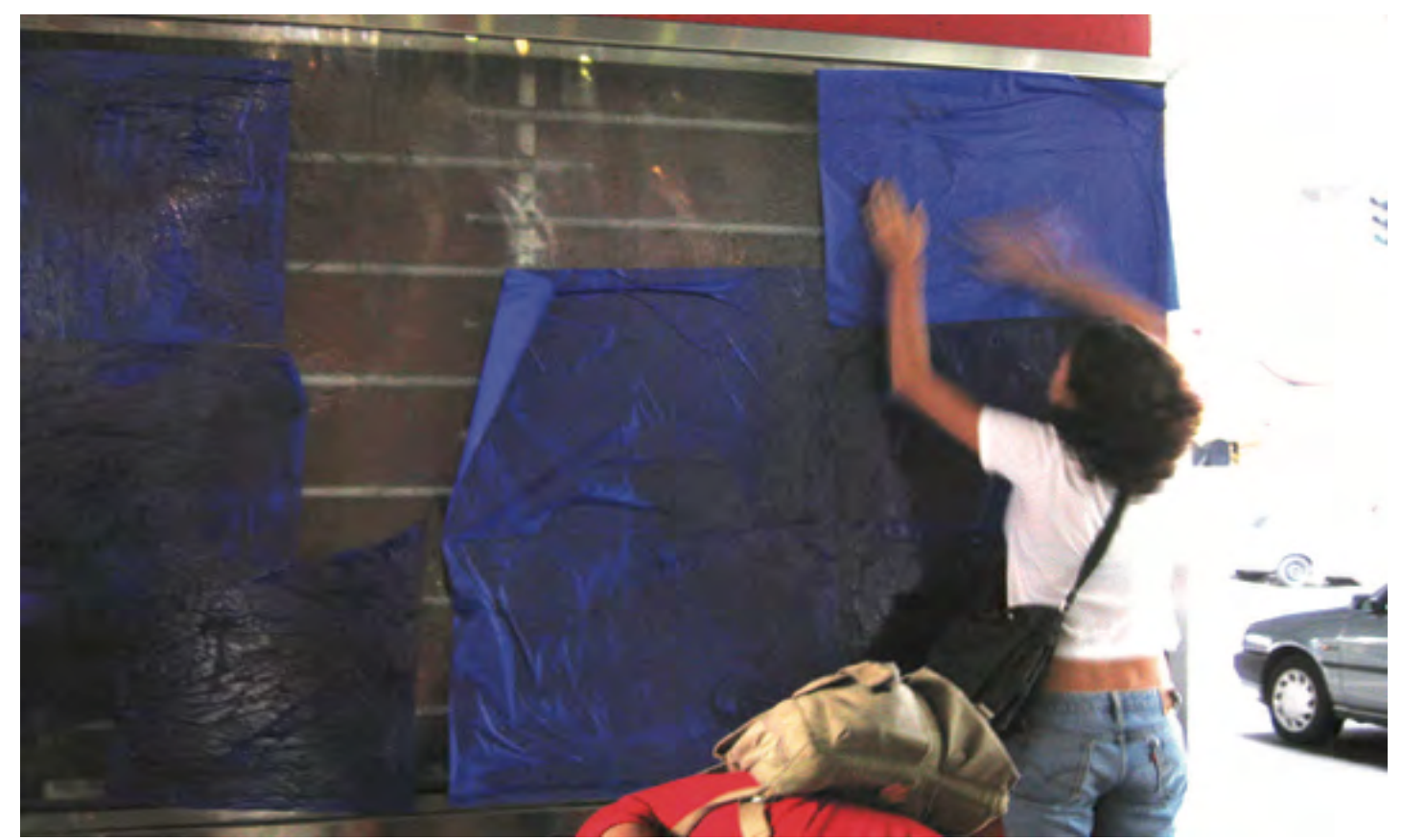

Lúcia Galvão,"sem titulo",2006.

Fotos: Flora Rebollo 

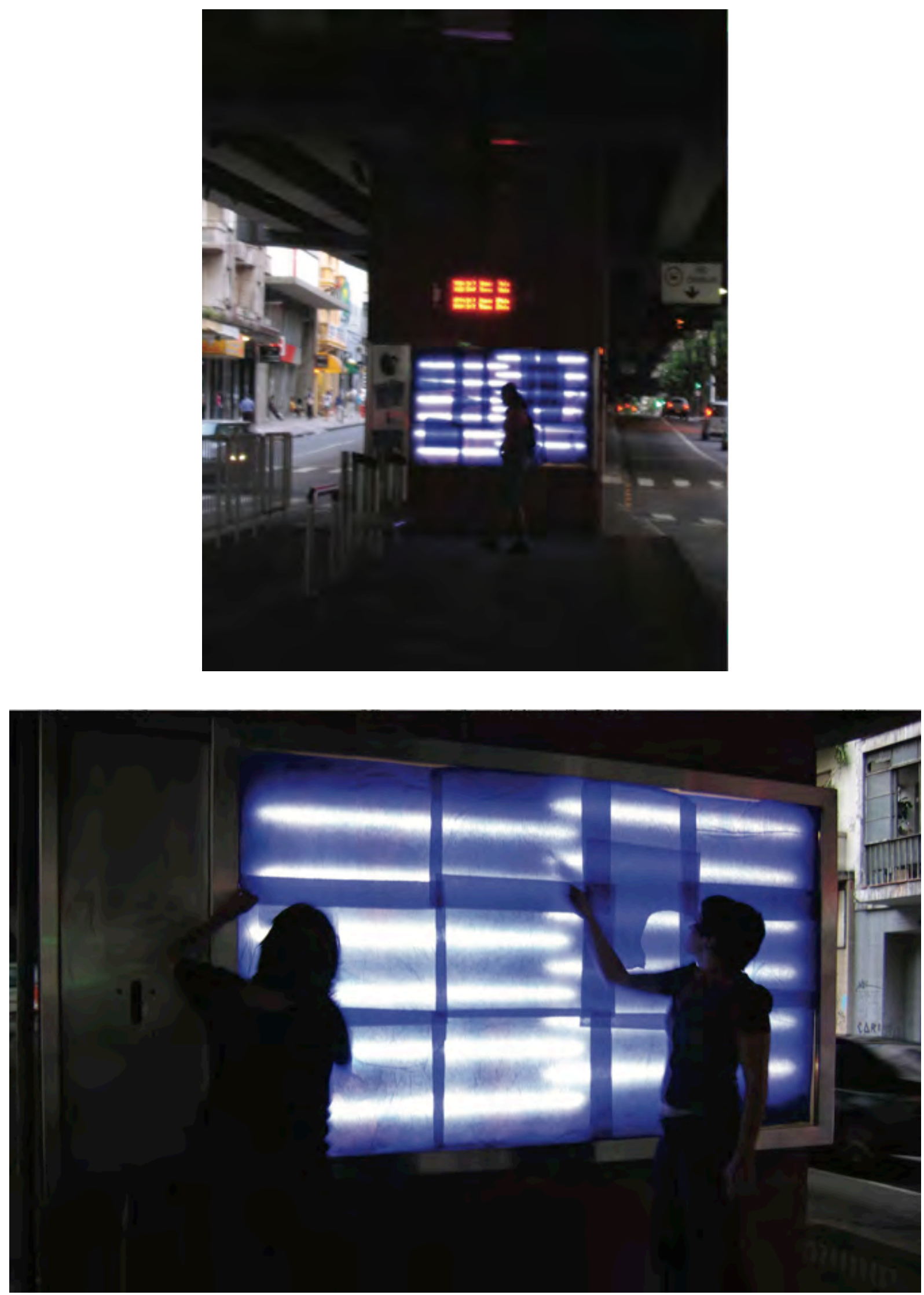

Lúcia Galvão, "sem titulo", 2006.

Fotos: Flora Rebollo 


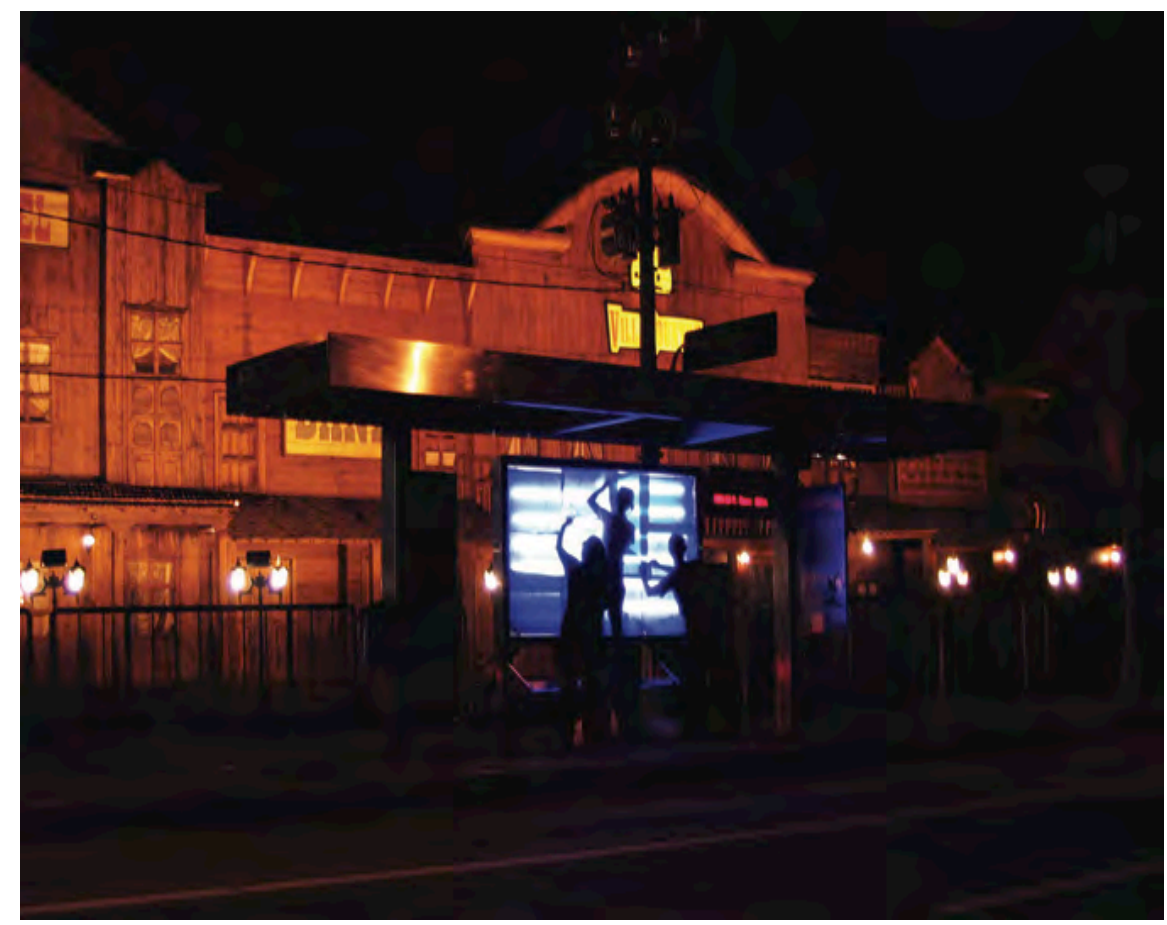

Lúcia Galvão,"sem titulo”, 2006.

Fotos: Flora Rebollo

A partir da primeira experiência com o azul, e dos efeitos plásticos daquela combinação de papel, textura, cola e lâmpadas, surgiu a vontade de elaborar mais as possibilidades de composição através do desenho. Por meio da impressão em silk-screen e partindo do próprio desenho que as lâmpadas formavam, chegou-se a um padrão que foi aplicado nas folhas de papel. Nesse caso a escolha cromática foi a de utilizar o papel rosa - criando um contraste entre a cor de fundo e o branco da lâmpadas - e estampa-lo com tinta preta. Devido a alta saturação do papel rosa, a cor rosa manteve um protagonismo na apreciação das intervenções, mesmo somando-se a questão do desenho a esse campo subjetivo pretendido.

De maneira não premeditada a cor rosa acabou sendo incorporada aos trabalhos e criando, posteriormente, uma narrativa possível na leitura das ações pela escolha dessa cor. Diante das experiências já citadas o rosa se estabeleceu com um campo cromático interessante de ser explorado no contexto de uma cidade como São Paulo; onde as relações na metrópole acontecem de forma extremamente impessoal, dura e muitas vezes violenta. 0 rosa de certa maneira propõe outros tipos de relação com a cidade. 

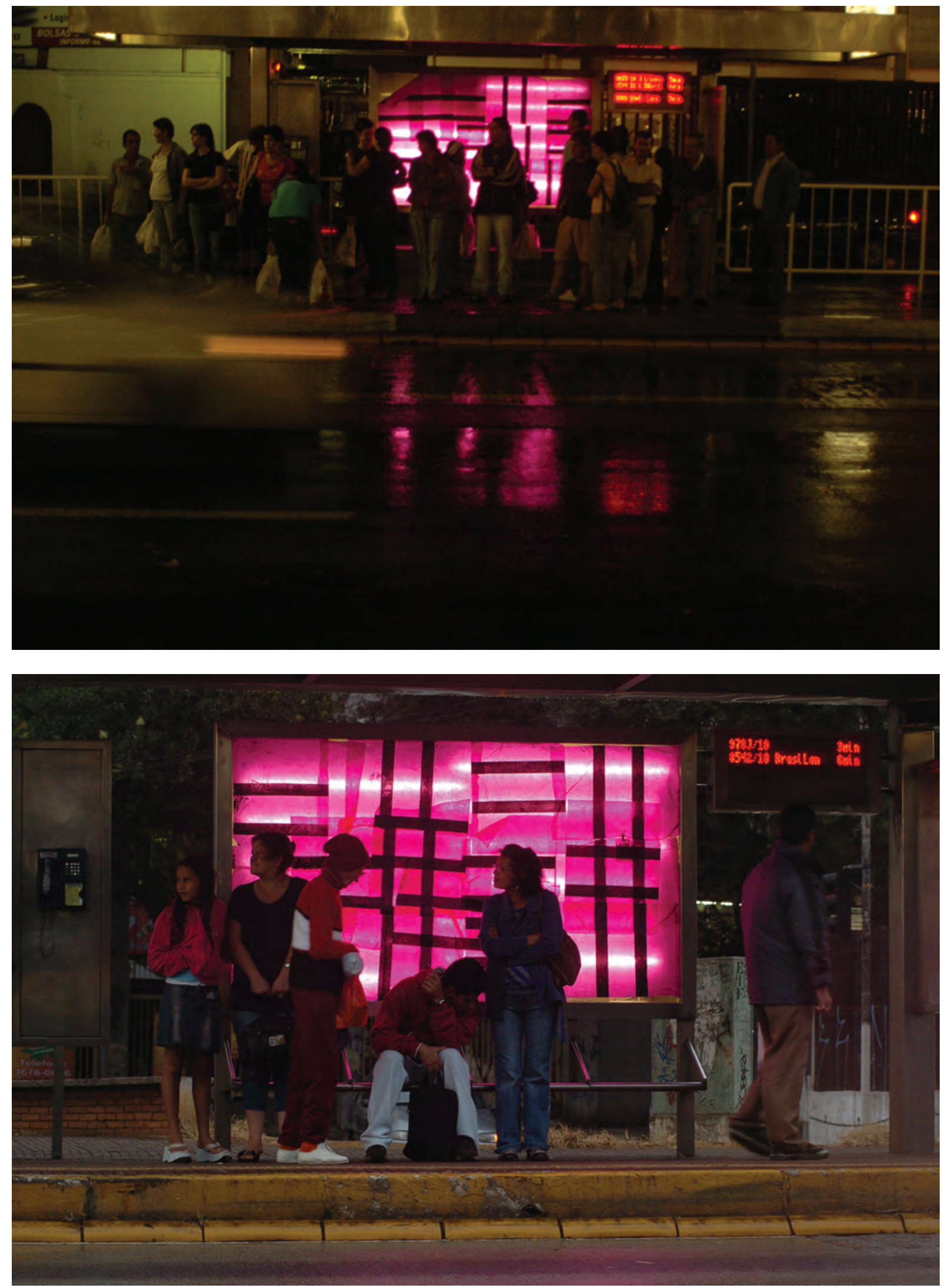

Lúcia Galvão,"sem titulo”,2006.

Fotos: Emiliano Capozoli 


\section{Rosa}

0 último trabalho realizado dessa serie de intervenções urbanas foi desenvolvido para a exposição "Em Obras". Partindo do convite da curadoria Lápis, realizei um projeto de iluminação para a fachada do casarão localizado na Av. Paulista nำ1.919. 0 trabalho foi planejado em duas etapas que, associadas, tinham a intenção de estabelecer um diálogo com o espaço da cidade e do casarão a partir da cor rosa - que também podemos chamar de rosa choque - que já havia sido utilizada em trabalhos anteriores.

A primeira etapa se deu a partir da aplicação - por todo o muro, grades e portão da fachada - de papel de seda rosa com cola de lambe lambe. Assim, em um primeiro momento, a cor renovou a fachada do casarão, que se encontrava bastante danificada. A ideia do empapelamento partiu da vontade de estabelecer uma relação temporal entre a casa e a exposição. 0 papel de seda aplicado com cola representava uma interferência transitória, já que se degradaria rapidamente e não teria muita durabilidade. Nesse sentido a condição efêmera do empapelar tinha a intenção de, a partir de uma aparente revitalização transitória, apontar e chamar atenção para o processo de deterioração que o próprio prédio vinha sofrendo.

O casarão, remanescente da Belle Époque da elite paulistana, pode ser visto como uma ilha no cenário corporativista da avenida e encontrava-se naquela ocasião em plena decadência. A exposição permaneceu em cartaz por um mês e ao longo desse tempo as pessoas que transitaram pelo local puderam experimentar diferentes percepções da fachada: desde uma total revitalização em um primeiro momento até, ao seu final, com os papéis deteriorados produzindo uma nova atenção sobre a fachada e um retorno à situação de abandono em que o prédio se encontrava.

Uma outra camada do trabalho foi o projeto de luz que consistiu em dez refletores de vapor de sódio instalados com gelatina rosa nas torres do muro em frente da casa. Um dos pontos principais do projeto é que esses refletores miravam o chão da calçada, criando um corredor de luz no lado de fora do casarão, um tipo de passarela. A intenção era criar uma tensão com o passante da rua e subverter a relação que geralmente se estabelece com esse tipo de refletor - usado para iluminação de prédios, monumentos, obras públicas, etc - a partir de, simplesmente, um novo posicionamento da luz. Além disso havia o desejo de criar, junto com o muro empapelado, uma superfície de grande saturação cromática que pudesse provocar o imaginário dos transeuntes, muito acostumados ao ambiente corporativo da avenida onde o casarão estava inserido.

A avenida Paulista é um lugar de saturação de luz, onde é muito comum a utilização desse tipo muito potente de lâmpada de vapor para dirigir a atenção dos transeuntes para os edifícios. Mas o que ocorre de fato é que esta iluminação se perde dentro desse contexto 
saturado e acaba se confundindo com a paisagem. Desta forma, quando um novo campo de luz e cor foi instaurado, houve uma alteração na relação do pedestre com aquela paisagem e um convite a uma novo tipo de interação. De fato, ao longo da permanência do trabalho, a fachada do casarão se transformou em palco para diversas manifestações espontâneas. Embora na Avenida Paulista exista a presença de uma grande diversidade cromática, a relação entre pedestres e passageiros com esta paisagem acontece principalmente ao longo de largas calçadas e de diversas faixas de asfalto, tendo como campo visual na maior parte das vezes o chão. Assim, acaba se constituindo um imaginário de paisagem acinzentada. A intervenção na fachada do casarão tinha intenção de utilizar a cor como elemento de desvio nesta relação com a paisagem.

O empapelamento que ocorreu no dia da abertura da exposição começou no fim da tarde. 0 objetivo era que o processo fosse realizado durante o pôr-do-sol, momento em que o céu começa a mudar de cor, de maneira que ao anoitecer as luzes se acenderiam para iluminar a performance. A ação foi uniformizada no sentido de se estabelecer uma relação irônica do trabalho com o título da exposição - "Em Obras" - numa referência às obras realizadas na avenida durante todo o ano de 2008.

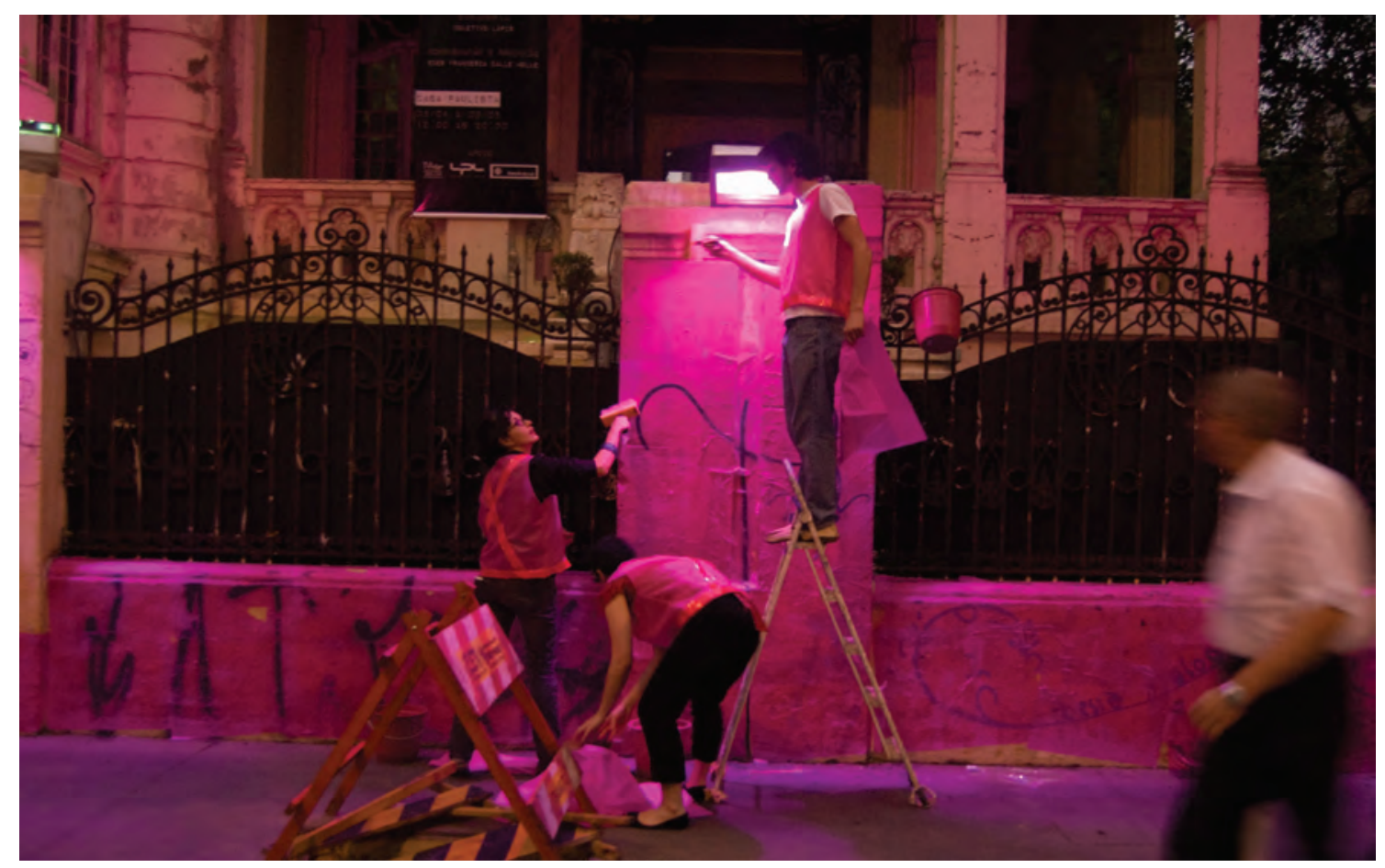

Lúcia Galvão, “ROSA”, 2009.

Foto: Pedro Terra 

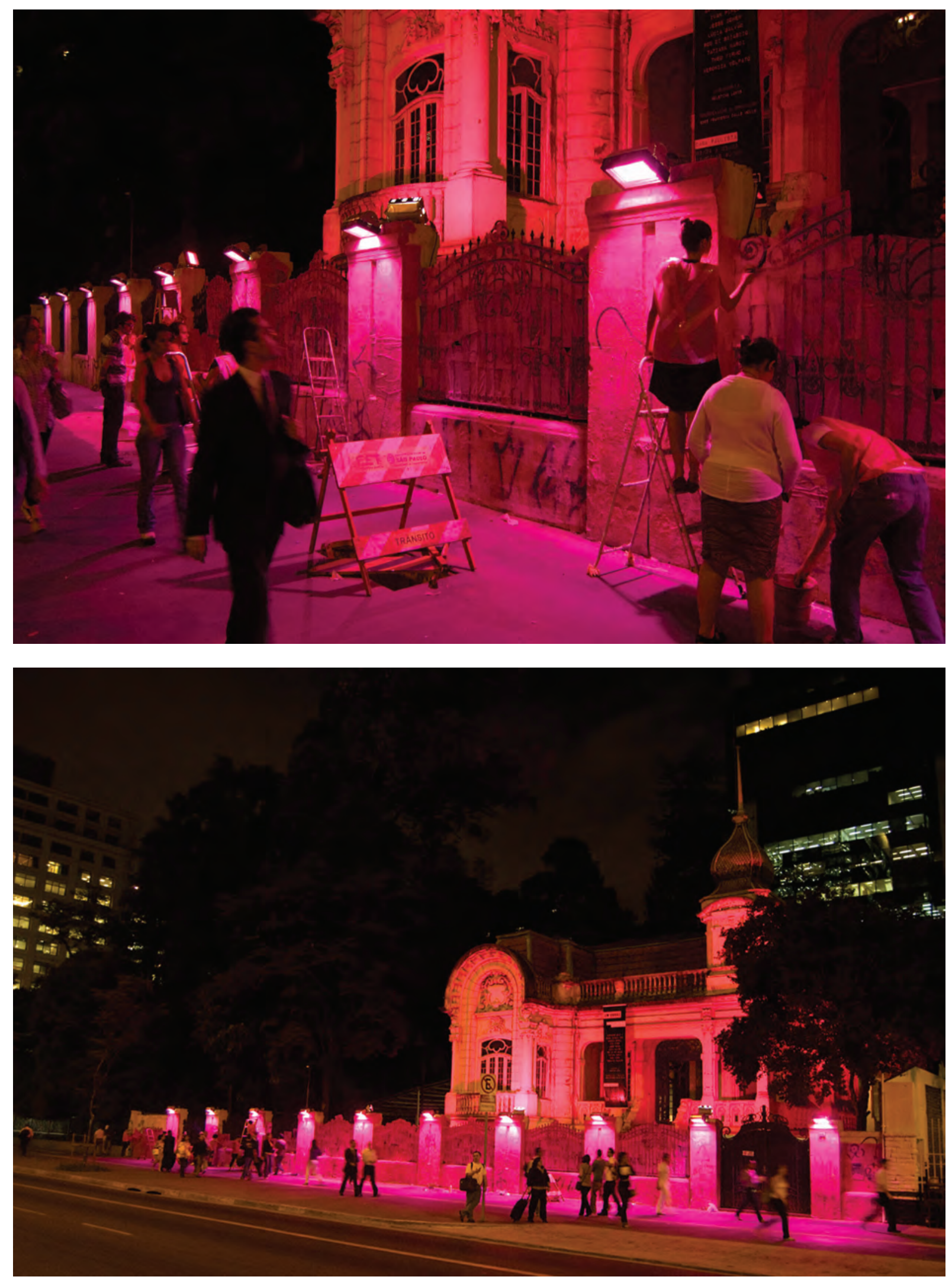

Lúcia Galvão, “ROSA”, 2009.

Foto: Pedro Terra 


\section{Preâmbulos}

Desde o início essa pesquisa tencionava desdobrar-se em um trabalho proposto para a cidade de São Paulo. E nesse sentido comecei a buscar um objeto de estudo que pudesse ser uma base interessante para uma nova proposição interventiva. A partir do curso "Lugares de Memória e Consciência: Teoria e Intervenção", ministrado pelos professores Renato Cymbalista e Giselle Beiguelman na FAU, surgiu o interesse de aprofundar um estudo sobre o bairro do Bixiga, ou Bexiga - as duas formas são aceitas e usadas. A disciplina tinha como objetivo conceituar o entendimento sobre lugares de memória e consciência, além de refletir acerca de algumas soluções projetais e urbanísticas dirigidas a lugares desse tipo a partir de um balanço historiográfico e teórico.

0 Bixiga, bairro central da cidade de São Paulo, está intimamente ligado à gênese da cidade, concentra um grande número de lugares de memória e participa de disputas simbólicas e territoriais, desde o mais remoto desenvolvimento urbano da metrópole, até os dias atuais. 0 bairro é palco hoje de uma série de conflitos políticos, entre os quais está a histórica disputa entre o Teatro Oficina e o Grupo Silvio Santos pelo terreno vizinho ao Teatro, e que hoje está representada na luta pelo Parque do Bixiga. Atualmente a região é palco de disputa entre forças opostas. De um lado o projeto de "gentrificação" e transformação de um dos bairros mais tradicionais da cidade de São Paulo, que é historicamente popular. Do outro as forças de resistência que pretendem preservar e resgatar a história do bairro. É o caso do Teatro Oficina e outras forças insurgentes da região, como o movimento Parque Augusta, os movimentos de moradia popular, além de outros agentes culturais, como a Associação Novo Olhar ${ }^{13}$. Em 2017, a expulsão violenta e truculenta de centenas de famílias que moravam debaixo do Viaduto Jaceguai pela Polícia Militar foi reveladora dessas forças em disputa, que representam duas visões conflitantes em relação ao desenvolvimento da região. De um lado, a preservação histórica do bairro, a partir de um olhar humanizado que respeita e valoriza a potência natural e popular que ainda existe naquele território. De outro, a visão do capital financeiro e da especulação imobiliária que desconsidera a dimensão simbólica daquele lugar.

Meu envolvimento com o bairro começou no fim de 2006, quando tive a primeira passagem pelo Teatro Oficina, participando como operadora de luz da banda, na gravação do dvd de "Os Sertões". Na ocasião, os cinco espetáculos da épica encenação da companhia

13 A Associação Novolhar atua há 19 anos no Bixiga com a finalidade de contribuir para a inclusão social de crianças, jovens, família e comunidade. <http://novolhar.org.br/sobre-a-novolhar/ 
foram remontados e filmados numa maratona que durou quase dois meses. Depois tive o prazer de acompanhar, em 2007, o grupo na montagem de "Os Bandidos" em Mannheim, na Alemanha, como assistente da iluminadora e diretora Cibele Forjaz. No ano seguinte, a peça seguiu em cartaz em São Paulo e operei a luz do espetáculo podendo dar seguimento à pesquisa em parceria com Ricardo Moranez. No ano de 2008 a companhia completava 50 anos e participei desse rito como iluminadora e operadora de luz. No ano de 2009 me afastei do grupo e fui trabalhar com o grupo Teatro de Narradores, desenvolvendo o projeto de luz para o espetáculo "Cidade em Desmanche", encenado no Espaço Maquinaria, a antiga sede do grupo localizada na rua 13 de Maio - atual sede do Casa Palco liderado hoje por Guilherme Bonfanti e Marisa Bentivegna. Após esse período fiquei anos afastada da região, até que em 2016 fui convidada por Cibele Forjaz a inteirar o coro de luz que ela estava formando para a remontagem do espetáculo "Bacantes", do qual participei como operadora de luz móvel (pin-bean).

\title{
3.2_0 BIXIGA
}

\author{
“ O Bixiga não é um bairro, não é um distrito, \\ o Bixiga é um território, um território de resistência" \\ Paulo Santiago, diretor da Associação Novo Olhar, \\ em evento pelo Parque Bexiga no Teatro Oficina.
}

O bairro possui essa alcunha - Bexiga - desde o final do século XVIII, devido ao nome dado à uma das chácaras que ocupavam seu território geográfico e ao seu proprietário que possivelmente foi vítima de varíola, doença que se proliferou na cidade naquela época. A formação do bairro faz parte do nascimento da metrópole e desde então, a história da região foi marcada pela resistência à sucessivos ataques da especulação imobiliária. A ocupação desse território também se relaciona à história dos rios da cidade de São Paulo. 0 bairro surge encravado no vale do Anhangabaú e seus afluentes Saracura e Bexiga conferem à região uma geografia de relevos bastante acidentados. No inicio de sua ocupação, era uma região com uma enorme exuberância de árvores frutíferas e uma riquíssima fauna.

Com o crescimento da cidade impulsionado pelo ciclo econômico do café, foi no século XIX que a ocupação do bairro aconteceu de forma mais intensa, especialmente a partir de meados dos anos 1880 - que antecedem a abolição da escravatura em 1888. 0 estimulo 
dado pelo governo Imperial à imigração foi responsável pelo enorme contingente de imigrantes italianos que se instalaram na região. Mas o bairro - devido a suas características geográficas - também abrigou muitos escravos fugidos e recém alforriados. Assim, embora até hoje seja sustentada, propositalmente, a ideia de que o Bixiga é um bairro majoritariamente italiano, na realidade a região sempre foi marcada pela multiplicidade cultural e étnica. No começo do século XX por exemplo, podia-se encontrar no bairro, além de italianos, portugueses, espanhóis e, principalmente, negros.

0 bairro se formou entre 3 riachos afluentes do Rio Anhangabaú: o riacho do Saracura, o riacho do Bexiga e o riacho Itororó. Esses córregos implicavam um relevo bastante irregular, o que tornava a região pouco propícia e atrativa para a ocupação. Assim, por conta de seu baixo valor de mercado, a região atraía apenas camadas médias e pobres da população em expansão. Essas características faziam daquelas matas um lugar convidativo para o esconderijo de negros rebelados, que se aquilombavam nas capoeiras e campinas existentes ali.. Com a Abolição, em 1888, houve uma explosão no número de quilombos que se formaram na região, de maneira que o bairro abrigava uma mescla de imigrantes e muitos negros ${ }^{14}$.

A arquiteta Sheila Schneck no texto "O nascimento de um bairro: o Bixiga (18811914)"15 analisou detalhadamente os documentos de propriedade no bairro desde sua formação e apontou para o fato de que, já no começo do século XX, houve uma exploração locatícia dos imóveis no âmbito do mercado imobiliário rentista vigente. Desta forma a propriedade dos imóveis se concentrava na mão de poucas famílias que, segundo a autora, exploravam o mercado de locação até as últimas consequências. Nessa época houve uma imensa proliferação de cortiços no bairro que abrigavam uma população majoritariamente negra. Ao mesmo tempo que as regiões próximas às nascentes desses riachos acerca da Avenida Paulista - abrigavam casarões e palacetes da aristocracia cafeeira. Em 1883 os proprietários de terrenos no bairro - na tentativa de revestir a região com tom menos depreciativo e agregar valor aos seus empreendimentos - solicitam na Câmara Municipal, por meio de um abaixo-assinado, a mudança do nome de "Campos do Bexiga"

14 "Como consequência, nos anos finais da escravidão os principais centros da época assistiram a uma verdadeira explosão no número de quilombos que se formaram em seus entornos. Muitas pessoas, ajudadas pelos movimentos abolicionistas ou por ex-cativos, abandonavam as fazendas para buscar a liberdade, misturando-se às pequenas multidões de anônimos que começavam a se formar nas cidades, ou dirigiam-se para os chamados quilombos urbanos, onde estabeleciam moradias precárias".

(CASTRO, 2008, p.42)

15 SCHNECK, pág. 309, apud HIKIJI, Rose S. G.; SILVA, Adriana de Oliveira (orgs.), 2014 
para "Campos da Bela Vista". A partir de então o bairro, dentro de seus limites formais, passou a chamar-se oficialmente de Bela Vista. No entanto o Bixiga é um território que permanece presente na fala e no imaginário das pessoas. Essa mistura cultural propiciou uma configuração bastante particular para o bairro, diferente de outros bairros operários em formação - também com forte presença da imigração italiana - como por exemplo o Brás e a Mooca. Como observa Lucena, o Bixiga se caracterizou pela multiplicidade cultural, desde uma vida noturna intensa com suas cantinas e serestas, até o aparecimento do cordão "Vai- Vai" reforçando a tradição do samba e a ligação com as raízes afro. ${ }^{16}$

\section{Avenida Nove de Julho e Elevado Costa e Silva}

Desde o começo do século vinte o sistema viário foi o elemento estruturador da expansão urbana de São Paulo, o que se consolida na década de 1930 com o Plano de Avenidas de Prestes Maia. A construção da Avenida Nove de Julho foi muito marcante na formação do bairro e é simbólica porque aponta para a lógica que marcou o crescimento da cidade e determinou as ações do poder público e do poder econômico na região. Em "Lembranças eu tenho da Saracura: escavando histórias soterradas por uma avenida", Marco Virgílio da Silva ${ }^{17}$ mostra como a Avenida representa uma estrutura urbana que se sobrepõe e soterra uma ocupação anterior - um dos espaços de memória mais importantes das comunidades negras que ocupavam os arredores da cidade de São Paulo. Desta forma antes do estabelecimento da identidade italiana que se formou no bairro, no início do século XX, o Bixiga abrigava uma população negra que ali vivia e praticava suas artes e festejos. Para o autor o projeto da Nove de Julho pode ser lido também como a culminação de um projeto de cidade baseado na privatização de bens coletivos, como a água, na remodelação de uma área desprestigiada por ocupações pretéritas de má lembrança, e a expulsão de uma população tida como indesejável. (SILVA, 2014, p.281 e 282).

0 autor destaca como as políticas higienistas do começo do século - que optaram pela desativação dos tanques e chafarizes públicos privatizando o acesso à água - são marcadas

16 A crise econômica de 1929, que determinou o término da monocultura cafeeira, provocou aumento da população e dos bairros operários na cidade de São Paulo à medida que provocou crescimento industrial. A partir de 1930, o bairro amplia sua multiplicidade de costumes, caracterizando-se por uma típica vida noturna, com a presença italiana e suas cantinas, muita música, dança, tarantela, serestas, o futebol do bairro, o aparecimento do cordão "Vai-Vai", o acentuado aumento das habitações coletivas, denotando miscigenações e a multiplicidade cultural. (LUCENA, 1984, pág.49)

17 (apud HIKIJI, Rose S. G.; SILVA, Adriana de Oliveira (orgs.), 2014) 
pela vinculação entre higiene, moralização e controle do espaço público no que diz respeito aos usos coletivos ${ }^{18}$. É possível notar que o poder público sempre atuou na região de forma a apagar uma série de memórias afetivas e também territoriais. Desde as primeiras políticas higienistas que levaram ao soterramento do Saracura e de outros afluentes do Anhangabaú, culminando na construção da Avenida Nove de Julho, até a construção da ligação expressa Leste-Oeste que atravessou o bairro de forma bastante violenta. Nesse processo, além da destruição de muitas casas históricas, não foi levada em consideração a vida afetiva do bairro, que se caracterizava pela intensa movimentação de pedestres entre os diversos teatros e restaurantes. Camila Teixeira Gonçalves, em sua dissertação de mestrado intitulada "Intervenções contemporâneas no Bixiga: fissuras urbanas e insurgências", define essa intervenção como uma fissura da área do bairro:

"Esta grande intervenção fissurou a área do Bixiga, ignorando a realidade das preexistências, destruindo casas históricas, segregando partes de um mesmo complexo, mutilando espacialidades e deixando áreas de vazios urbanos embaixo de seus viadutos, que hoje são assolados por problemas de toda ordem, quer sociais, quer físicos, sem usos e conexões com o restante da cidade, reproduzindo o tipo de intervenção que a Avenida 23 de maio anteriormente iniciou." (GONÇALVES, 2016, p.51)

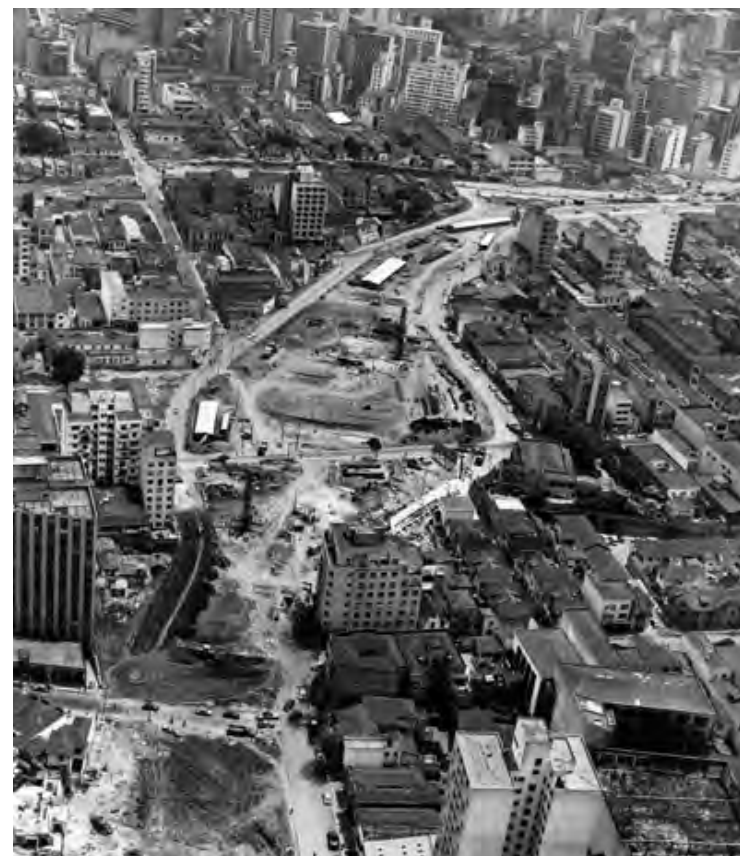

18 SILVA, 2014, pág.285 


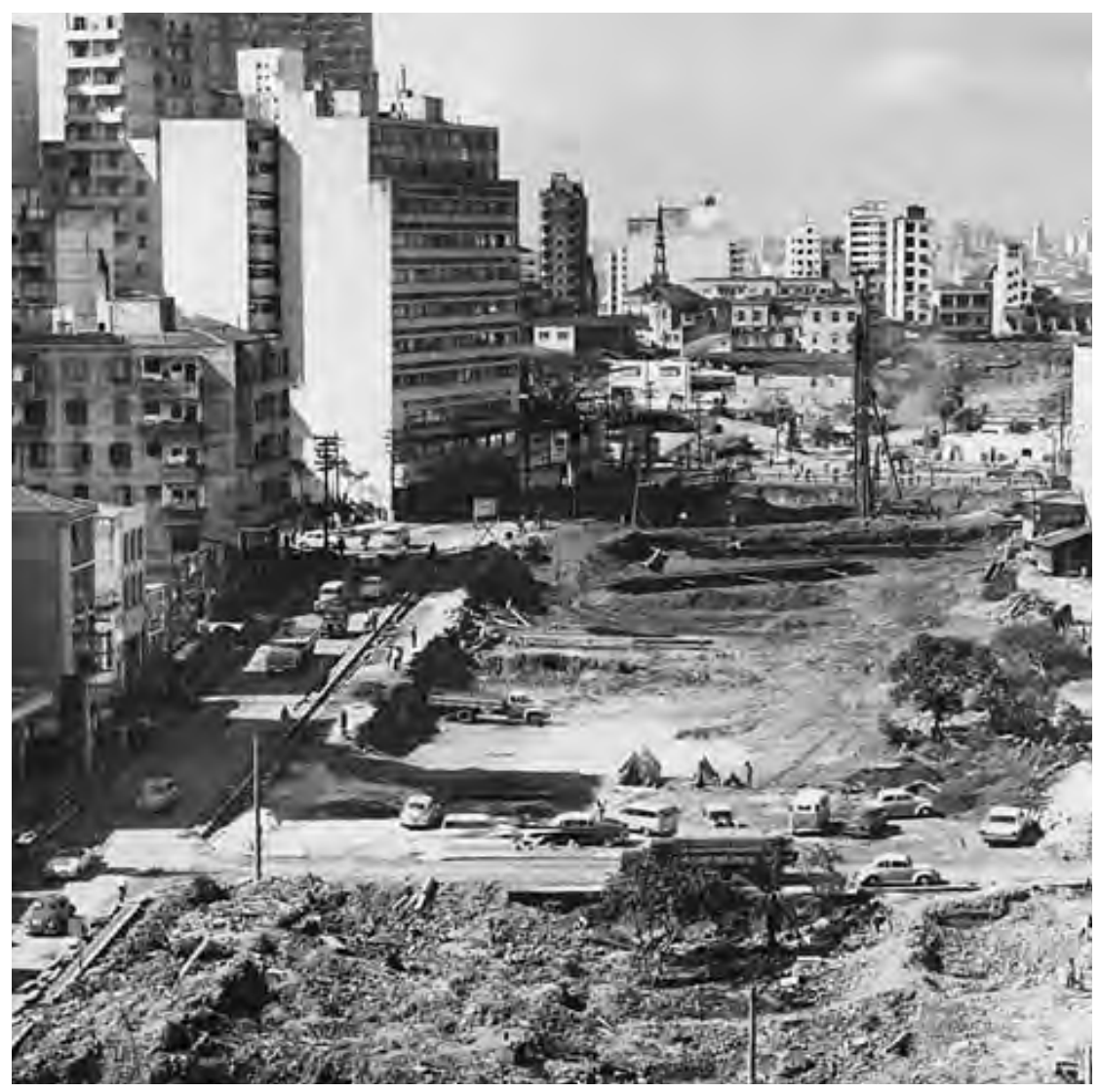

Construção do Minhocão em frente ao Teatro Oficina, 1969.

Coleção iconográfica Casa da Imagem, Prefeitura de São Paulo.

FONTE: http://teatroficina.com.br/teatroficina/

\section{Oficina Uzyna Uzona e breve cosmologia do Anhangabaú da Feliz Cidade}

O Teatro Oficina surgiu em 1958, na Faculdade de Direito do Largo São Francisco como um movimento - "A Oficina" - que buscava um novo tipo de teatro, distante do caráter burguês do teatro produzido no $\mathrm{TBC}$, assim como do viés nacionalista do Teatro de Arena. As montagens dessa primeira fase eram inspiradas em leituras existencialistas e tinham caráter amador. 0 grupo era composto, entre outros, por José Celso Martinez, Renato Borghi e Fauzi Arap. Em 1961, com a aquisição do Teatro Novos Comediantes, na Rua Jaceguai, no Bixiga, a companhia se profissionalizou e foi criada a sala de espetáculos que em 1966 seria destruída por um incêndio. Mesmo assim o grupo atravessou os primeiros anos do golpe militar com montagens bastante experimentais e viveu seus anos 
dourados até o final da década de 1960 com montagens consagradas como " O Rei da Vela" (1967) e " Na Selva da Cidades (1969) ${ }^{19}$.

É importante chamar atenção para o tipo de ocupação do espaço que já desde essa época era proposto pela companhia, buscando um novo modo de interação - simbólica e material - com o bairro e o entorno no qual estava inserida. Para a construção do cenário de "Na Selva da Cidades", por exemplo, a arquiteta Lina Bo Bardi, que era cenógrafa do espetáculo, recolheu os entulhos dos sobrados demolidos para a construção do Minhocão. Nesse período, funcionava no interior do teatro a "Cantina Cabaré da Zuria" uma cozinha comunitária popular que recebia, entre outras pessoas, operários de toda parte que chegavam para a construção do viaduto.

A década de 1970, marcou a dissolução parcial do grupo e os anos de chumbo da ditadura militar - entre 1971 e 1978 - impuseram o exílio à Jose Celso Martinez Correa. Após esse período o Teatro retomou gradualmente seus esforços, passando a acolher programações que extrapolavam a apresentação de peças teatrais: cantina, cabaré, sala de exibição de filmes, ágora. Essa expansão se ligava ao interesse do grupo em pensar as relações espaciais entre palco e plateia. Em função das obras de transito promovidas pelo poder público no bairro - principalmente a ligação expressa Leste/Oeste - surgiu uma nova onda migratória no Bixiga, de população nordestina. A partir daí se deu a interação da companhia com músicos nordestinos, como por exemplo, o grupo "O Forró do Avanço", que acabou contribuindo para a incorporação de alguns elementos que serão constitutivos da atual identidade do Oficina. Advém daí, por exemplo, a relação com a terra e a incorporação de cirandas e cantos xamânicos em seu repertório.

Nesse período, os arquitetos Lina Bo Bardi e Edson Elito começaram a explorar as possibilidades cênicas do espaço físico do teatro destruído e a elaborar um projeto de reconstrução composto de muitas camadas de articulação com a cidade. Desde a vontade de deixar a luz do sol entrar no teatro através de uma abertura lateral, até dimensionar um projeto que dialogasse com seu entorno, através de barracões nos baixios do viaduto e a arborização do terreno ao lado dessa abertura (face oeste do teatro). De forma que esses estudos se relacionavam também com outras propostas de Lina Bo Bardi como a apresentada, em 1981, para a revitalização do Vale do Anhangabaú.

19 TEATRO Oficina. In: ENCICLOPÉDIA Itaú Cultural de Arte e Cultura Brasileiras. São Paulo: Itaú Cultural, 2019. Disponível em: <http://enciclopedia.itaucultural.org.br/grupo112413/teatro-oficina>. Acesso em: 08 de Out. 2019. Verbete da Enciclopédia.

ISBN: 978-85-7979-060-7 
E foi também nessa mesma época que o Grupo Silvio Santos começou a comprar os lotes do entorno do teatro para uma investida especulativa com os imóveis do bairro. Em novembro de 1980 o Grupo Silvio Santos pressionou e ameaçou a companhia tentando obter sua sede. Após uma grande mobilização da opinião pública e da imprensa, Silvio Santos anunciou publicamente sua desistência. A partir desse movimento, em 1982, o Teatro foi tombado pelo CONDEPHAAT, tendo Aziz Ab'Saber como presidente e Flávio Império como conselheiro. No ano seguinte, foi desapropriado pelo estado, tornando-se um espaço cultural sob a direção do Oficina, e, ao longo da década de 1980, o antigo teatro com projeto de Flávio Império foi sendo demolido, com a anuência deste, para a construção do projeto arquitetônico de Lina Bo Bardi e Edson Elito.

Em 1991, o arquiteto Paulo Mendes da Rocha desenvolveu um novo estudo a partir do projeto original de Lina Bo Bardi, propondo a travessia do viaduto e criando, numa sobra de terreno do outro lado da rua, duas torres que abrigariam a administração e o centro de memória do teatro, além de um bar. No entanto este projeto não se realizou e, somente em 1993, o teatro foi finalmente reinaugurado com a nova edificação feita a partir do projeto de Bardi- Elito. Este momento inaugurou uma nova fase da companhia, em que se radicalizava a vocação do grupo para montagens musicais, com grande participação de elenco coral e banda ao vivo.

Após consagradas montagens, como Hamlet (1993), Bacantes(1996) e Cacilda! (1998), o início do século XXI marca uma virada na companhia com "Os Sertões". Esse processo de trabalho que durou 7 anos - de 2000 até 2007 - resultou em cinco peças sobre obra de Euclides da Cunha e aprofundou a atuação social da companhia no bairro. Nasceu, em 2002, o Movimento Bexigão, com o objetivo promover a inclusão de jovens em situação de risco social, por meio da arte e de oficinas. Durante a montagem esse movimento incorporou crianças moradoras das ocupações e dos cortiços do bairro para formar um coro de crianças sertanejas que atuariam na peça.

Paralelamente, nesse inicio de século o Grupo Silvio Santos seguiu com seu projeto especulativo naquela região e, pouco a pouco, foi comprando todas as casas no entorno da face oeste do Teatro, incluindo imóveis tombados e uma sinagoga. Essas casas foram demolidas e a área foi transformada em um estacionamento. No ano 2000 foi aprovado pela Prefeitura, a construção do Shopping Center Bela Vista Festival Center nesse terreno pertencente ao Grupo SS. Porém, a construtora se negou a seguir os parâmetros construtivos do município e, por medida cautelar, a obra foi embargada. Em 2004 o Grupo SS convida o escritório Brasil Arquitetura - coordenado por arquitetos que trabalharam próximos à Lina - para a elaboração de um projeto que pudesse atender às necessidades de mercado do grupo, com a construção do shopping center, mas com a contrapartida da inclusão de um projeto de Teatro de Estádio. 
O projeto mobilizou e dividiu a opinião pública, acirrando a tensão entre o Grupo SS e o Teatro Oficina. De um lado, a defesa de que o empreendimento teria o potencial de trazer revitalização para o bairro. Do outro, o Teatro Oficina problematizava o projeto, exageradamente adensado e alienado de seu entorno e da história do bairro. Existia a avaliação de que o ambicionado Teatro de Estádio - idealizado por Lina Bo Bardi como um teatro aberto à cidade - estaria confinado a uma caixa preta, descaracterizando-se totalmente a ideia original. Além disso, a proposta apresentada não considerava os recuos necessários e legais para a área envoltória de um bem tombado e comprometeria a transparência do janelão da fachada oeste. De forma que o projeto foi abandonado após o CONPRESP pedir alterações no desenho.

Diante desse impasse, Silvio Santos visitou o teatro durante a montagem de "Os Sertões" e surgiu ali, pela primeira vez, a ideia de uma possível troca de terreno com a União. A partir do vislumbre dessa possibilidade, a companhia resgatou o programa do "Anhangabaú da Feliz Cidade" e aprofundou uma proposta de implantação do Teatro de Estádio e da Universidade Antropófaga que funcionariam, junto da Oficina de Florestas, no terreno em disputa no entorno do teatro. ${ }^{20}$ Nesse momento um projeto arquitetônico foi elaborado por João Batista Martinez, irmão de Zé Celso Martinez. 0 projeto absorvia a experiência de montagem de "Os Sertões" e incorporava as curvas de nível da topografia de Canudos. Além disso, a ideia de uma Universidade Antropófaga se apresentava como proposta bastante pioneira na intenção de incorporar vários tipos de saberes, buscando uma formação mais completa a partir do entendimento do artista como agente de transformação social. Porém esse projeto não se viabilizou.

No ano de 2008 outra proposta foi apresentada pelo Grupo SS para o terreno em disputa: um condomínio residencial com 3 prédios de quase 100 metros cada, que no entanto também não conseguiu aprovação dos órgãos de preservação do patrimônio (CONPRESP, CONDEPHAAT e IPHAN). Até que em 2010 por ocasião das Dionisíacas - sequência de quatro espetáculos do repertório da Companhia: “Taniko", “Cacilda!!", “Bacantes" e "Banquete” - a companhia saiu em turnê por oito capitais brasileiras com apresentações em espaços

20 "Inspirada num antigo morador do Bixiga - o grande poeta modernista, pós-modernista e antropófago, Oswald de Andrade -, a Universidade tem como superobjetivo a formação não somente de atores para o teatro, cinema ou TV, mas atuadores na sociedade, nas zonas de conflito, áreas de risco, formados na experiência do estudo e contato com os pontos tabus, que impedem nossa evolução democrática para a liberdade, incorporando o ensino com crianças, adultos, através de experiências artísticas, filosóficas, científicas, e mergulhando nos temas tabus, evitados pela educação de péssimo padrão de hoje." <https://www.universidadeantropofaga.org> 
preparados para receber 2.000 espectadores dentro da perspectiva do Teatro de Estádio. E para as apresentações que foram realizadas em São Paulo, Zé Celso, conseguiu autorização do Silvio Santos para montar temporariamente o Teatro de Estádio no terreno em disputa, de modo que as apresentações acontecessem lá. A partir desse momento o grupo reestabeleceu relação com aquele espaço adjacente ao teatro e iniciou uma jornada de ressignificação e apropriação de alguns dos elementos com que entrava em contato. Por exemplo, a montanha de entulhos formada a partir dos escombros de todas as construções demolidas pelo Grupo SS - incluso aí a Sinagoga da Rua Abolição - foi batizada de Sambaqui e incorporada em diversas apresentações e rituais. Mais importante ainda foi a experiência de entrar de contato com aquele espaço esvaziado, fazendo com que o projeto do Teatro de Estádio de outrora começasse a perder sentido, e a potencia do vazio passasse a redirecionar tudo que seria pensado para aquele espaço de lá para frente.

Desde então Companhia tem incorporado esses signos em suas apresentações e promovido ações para a ressignificação daquele lugar. Nesse sentido, como é característico da linguagem do Teatro Oficina, essas ações se configuraram como rituais que apelam para um tipo de conexão com o espaço que transcende o da materialidade física, agregando valores místicos e incorporando diversas camadas de interpretação. Como aconteceu em 2011, quando o prólogo da peça "Macumba Antropófaga" saiu em cortejo pelo bairro com o objetivo de abraçar o terreno ao redor do teatro. É importante ressaltar que esse espetáculo foi bastante significativo, por resgatar os valores que a Universidade Antropófaga vislumbrava, tendo como inspiração fundamental o poeta - e habitante do Bixiga - Oswald de Andrade. A peça funcionou como um rito de abertura da Universidade, nas palavras do grupo, "a primeira dentição" da Universidade.

A partir de então, as ações que vieram sendo propostas para o entorno do Teatro revelaram-se muito significativas para essa pesquisa, pois já indicavam o território de interesse da proposta que será apresentada aqui na sequência. Por exemplo, o prólogo da "Macumba Antropófaga" relacionava alguns lugares de memória do bairro e que estão circunscritos nessa região em torno do terreno, sendo estes a última casa de Oswald de Andrade, o TBC (Teatro Brasileiro de Comédia) - que, apesar de ser tombado como patrimônio histórico da cidade, passa por um processo de degradação e está desde 2008 fechado para o público - e a Casa de Dona Yayá, um dos últimos casarões que representam o "cinturão de chácaras" que contornavam o centro da cidade no século XX e onde funciona atualmente o Centro de Preservação Cultural da Universidade de São Paulo. A encenação do Teatro Oficina articulava esses pontos com outros que estão ao redor do terreno criando gestos mágicos que buscavam a trazer vida e potência a esses espaços de memória que se encontravam - e infelizmente ainda se encontram- abandonados. 
Ao longo dos anos de 2012 e 2013 vários atos foram pensados e realizados nesse sentido. Por exemplo, em 2013, foi realizada a 'Acupuntura Urbana no Corpo de Sampã', uma expedição de artistas da companhia que realizou ações nas em obras de Lina Bo Bardi pela cidade de São Paulo:

\begin{abstract}
“Gestos mágicos, precisos como a plantação das árvores nativas evocadas por Lina no projeto do Palácio das Indústria, no terreno entorno ao Teatro; o Furo no Portal da Japurá; a sagração de uma árvore no Vale do Anhangabaú; a invocação do Rio do Bixiga, desviado do seu leito natural, do Córrego das Águas Pretas, confinado no canal de concreto e o rio Anhangabaú aterrado no fundo do vale, reafirmou a importância e a atualidade das obras de Lina a serem completadas e a urgência de pôr ao Vivo, os Rios Vivos de Sampã."21
\end{abstract}

Neste mesmo ano, na X Bienal de Arquitetura, que aconteceu na cidade de São Paulo, o arquiteto e professor Guilherme Wisnik assumiu a curadoria do evento e convidou o Teatro Oficina para uma residência com a intenção de desenvolver o programa "Anhangabaú da Feliz Cidade". A residência teria ainda o objetivo de elaborar um novo projeto para o terreno no entorno ao teatro com o apoio de outros arquitetos estrangeiros. De forma que o grupo formado para a residência resgatou os projetos e estudos desenvolvidos, ao longo de mais de quarenta anos, para aquele terreno e acabou incorporando em uma nova proposta, principalmente, as ideias desenvolvidas por Lina Bo Bardi, Edson Elito e Paulo Mendes da Rocha, transcendendo os limites físicos do terreno no entorno do Teatro e pensando aquele espaço como parte de uma rede que compõe a vida cultural no centro da cidade.

O grupo levantou algumas questões importantes a partir da tipologia do bairro. Considerando, por exemplo, a qualidade sinuosa e estreita das ruas, o projeto de verticalização que vinha sendo proposto para região, significaria uma paisagem privada de céu e sol. Ou ainda, pelo fato do bairro ser formado por artesãos, a combinação de residência/ oficina acabou fazendo dele um bairro de pedestres. E a partir de um mapeamento bastante cuidadoso de outros equipamentos existentes no bairro, o grupo elaborou o projeto de um Corredor Cultural, integrando o TBC, a Casa de D. Yayá e outros pontos de cultura e resistência como a Praça Roosevelt e o Parque Augusta, através de caminhos de pedestres

21 <http://teatroficina.com.br/anhangabau-da-feliz-cidade/cosmologia/ 
e ciclovias verdes. 0 projeto apresentou também novas propostas de uso para os espaços "vazios" que existem nos baixios do minhocão, privilegiando um uso público do espaço e criando áreas de convivência. Seguem aqui alguns dos mapas que foram elaborados na ocasião.

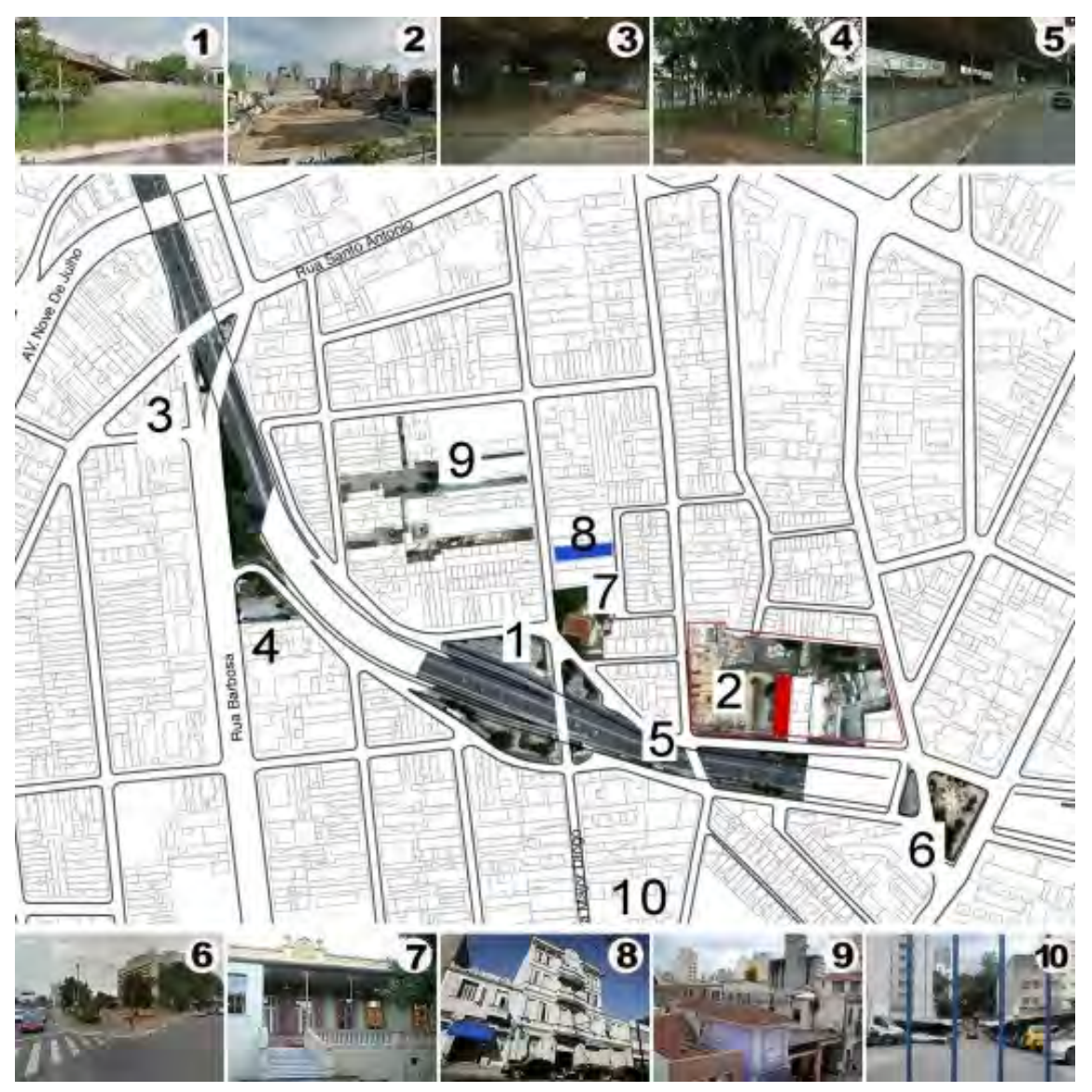

Vazios e equipamentos do Bixiga: 1) vazio próximo à rua Major Diogo; 2) terreno vizinho ao Teatro Oficina; 3) rua Santo Antônio; 4) praça Ítalo Bagnon; 5) rua Jaceguai; 6) praça Pérola Byington; 7) Casa de Dona Yayá; 8) Teatro Brasileiro de Comédia. 
A requalificaçăo urbana deste residuos deve conciliar um desenho urbano na escala do pedestre com um projeto de paisagem, incluindo usos năo convencionais de quintais e lotes vagos.
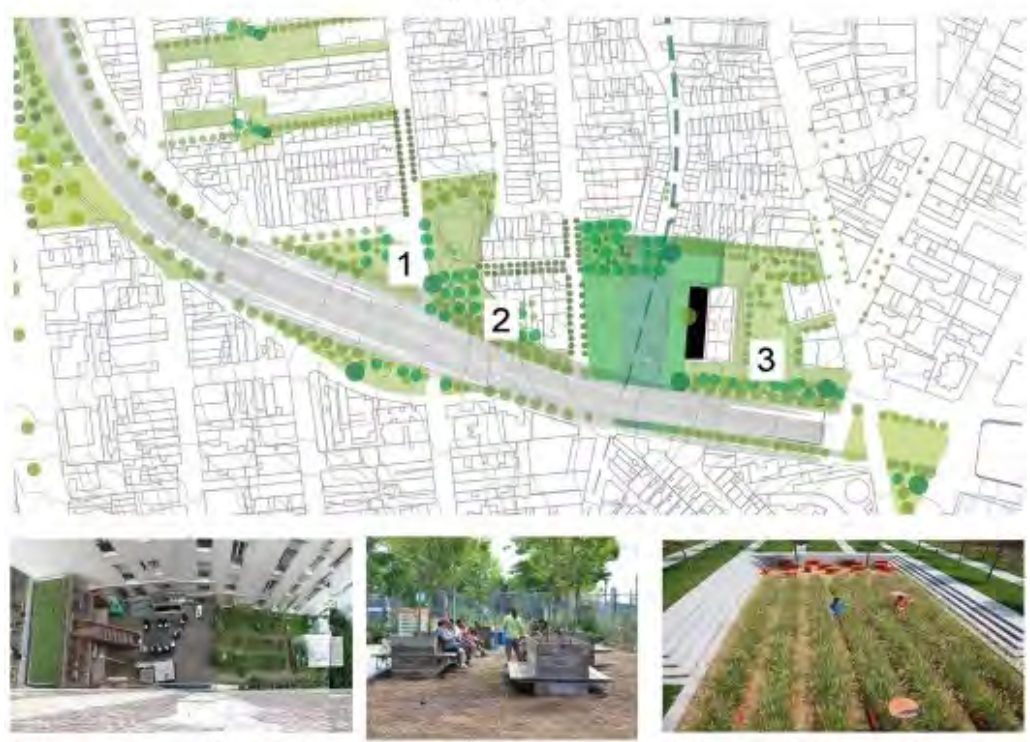

1_Jardins comunitários / Paris

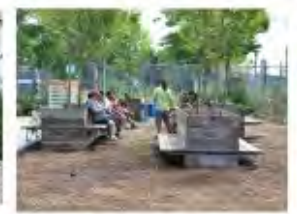

2_Viveiro de mudas I Brooklyn

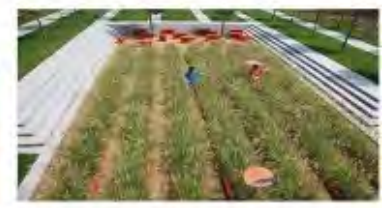

3_Agricultura Urbana / Turenscape

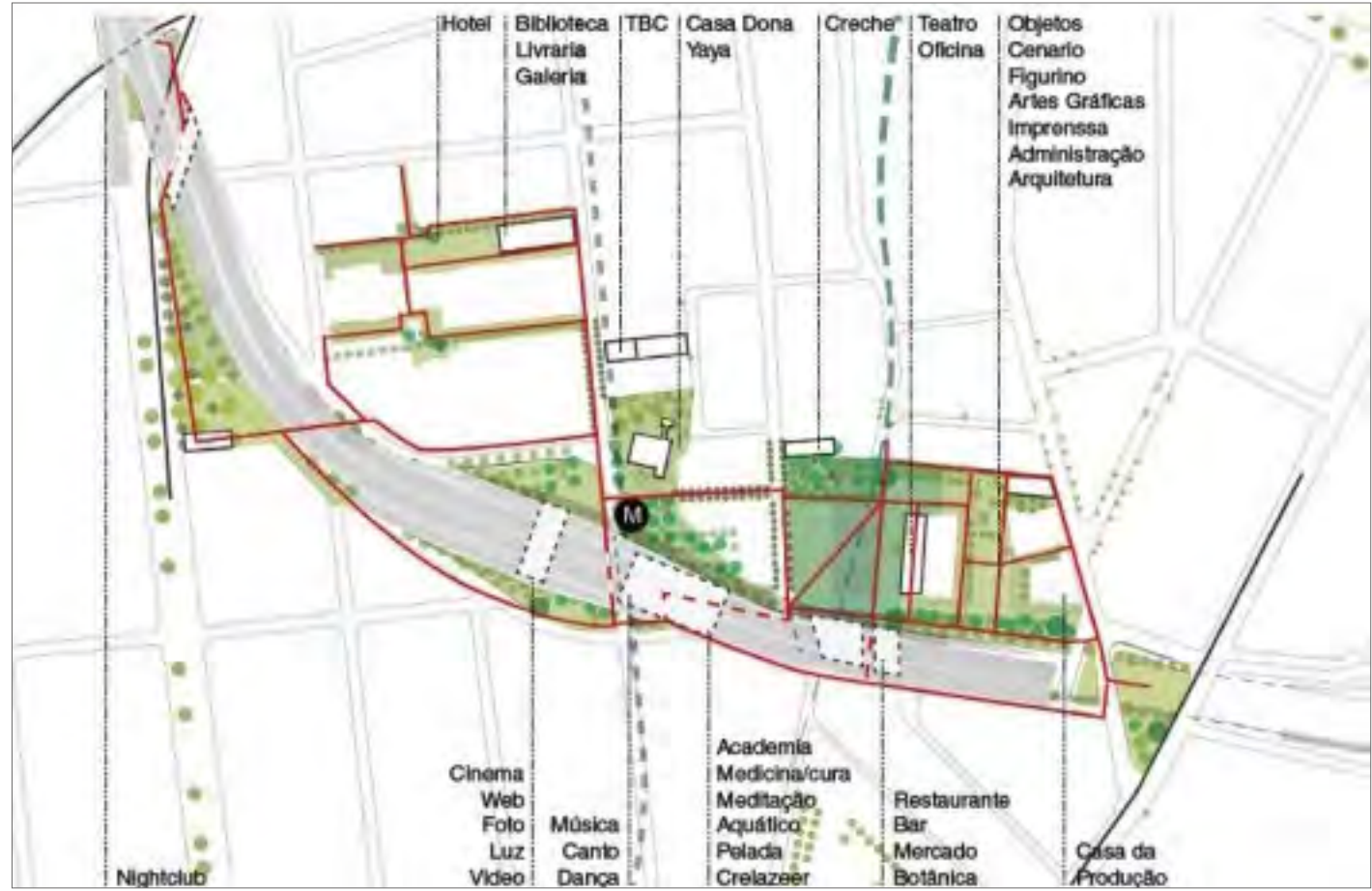

FONTE: http://vitruvius.com.br/revistas/read/minhacidade/15.180/5617 
Dando sequência aos achados da Bienal, em 2014, o Teatro Oficina promoveu o “Terreyro Coreográfico", buscando, a partir de diferentes perspectivas sensíveis, pensar e requalificar as dimensões do espaço público, e nesse caso especifico, dos baixios do Minhocão. Durante um ano foram realizados vários diferentes tipos de ação ritual e cultural naquele espaço na tentativa de - segundo o grupo - transformar o espaço e cultivar um lugar público que valorizasse a mistura e as diferentes perspectivas estéticas e culturais. Até que em 2015 aconteceu a "segunda dentição" da Universidade Antropófaga, que culminou na criação do "Teat(r)o Bloco Pau-Brasil", uma encenação que percorreu o bairro durante o carnaval de 2016 e em outras datas festivas. Nesse mesmo ano, o grupo se articulou e mobilizou a opinião publica contra a tentativa da Prefeitura de privatizar os baixios do viaduto, conseguindo derrubar a tentativa.

\section{Parque Bexiga}

Em 2017, ressurgiu a ameaça do Grupo Silvio Santos de construir as torres residenciais - 3 torres, com 100 metros de altura e 3 andares de estacionamento subterrâneo - sendo esta aprovada pelo CONDEPHAAT em outubro daquele ano, embora o terreno estivesse inserido na área envoltória de outros bens tombados para além do Teatro Oficina, como a Casa de Dona Yayá, a Escolinha Primeiras Letras e o Castelinho da Brigadeiro. Desde então o movimento pelo Parque do Bixiga começou a ganhar força e de lá para cá inúmeros debates públicos foram promovidos com o intuito de escutar a população do bairro e promover a discussão do tema; além de muitas ações e rituais visando atrair a atenção da opinião pública. A mobilização de diversos agentes culturais e políticos, culminou no projeto de resgate do Rio Bixiga, afluente do Anhangabaú que passa em baixo do terreno ao lado do Teatro.

Atualmente o Parque do Bixiga já tramita como um projeto de Lei (805/2017) que prevê, para aquele terreno de quase $11 \mathrm{mil} \mathrm{m}^{2}$, a criação de uma área verde pública, de característica cultural. A proposta é que o Parque, diferentemente daqueles pensados unicamente como áreas arborizadas, possa estruturar um programa público abrangendo cultura, educação, saúde e ecologia e resgatar o caráter histórico do bairro, tradicionalmente marcado pela diversidade cultural. O Bixiga é hoje o bairro mais adensado da cidade de São Paulo e a sua única área pública verde é a Praça Dom Orione, de forma que o bairro possuí o pior indicador de área verde dentro da Subprefeitura da Sé22. Diante dessa

22 https://medium.com/@uniantropofaga/o-parque-do-bixiga-\%C3\%A9-nosso-66162493bed8 
evidência a luta pelo parque é, também, uma luta que envolve questões de saúde pública do bairro; no caso da construção das torres, uma área gigante do Bexiga seria privada de luz solar durante quase todo o dia.

Em 05 junho de 2019 - dia do meio ambiente - foi realizado no Teatro Oficina o "Grande Ato em defesa do Parque do Bexiga". Para o evento foram convidados diferentes especialistas e muitos os agentes de resistência que atuam dentro e fora daquele território no sentido de pensar as questões referentes ao direito à cidade. Além de mobilizar a opinião pública em defesa do projeto de lei que tramita na prefeitura, o evento tinha como objetivo a apresentação pública de um novo projeto, desenvolvido a muitas mãos, por um grupo de arquitetos que se formou com intenção de estudar o projeto original de Lina Bo Bardi a partir da perspectiva do Rio Bexiga. Esse projeto tem como ponto de partida as características geográficas do terreno e propõe uma ocupação muito pouco adensada, em que o rio é o protagonista; resgatando assim as linhas originais de Lina Bo Bardi para pensar a ideia de um Teatro de Estádio, a partir da simplicidade radical, e de passarelas que percorrem o espaço.

O evento foi esclarecedor da urgência pela criação do parque e o resgate do rio, e do que isso significaria no contexto da cidade de São Paulo para os todos aparelhos no entorno do terreno, como por exemplo, a preservação da paisagem tombada nos jardins da Casa de Dona Yayá ou a ocupação Nove de Julho, e uma nova lógica de ocupação do centro da cidade. 0 projeto de intervenção que apresentarei na sequência surgiu de maneira intuitiva a partir da minha proximidade com as questões problematizadas pelo parque, e, quando me debrucei mais a fundo na trajetória descrita acima, pareceu-me fazer ainda mais sentido.

\section{Arco-íris da Feliz Cidade}

A questão do Parque do Bixiga transcende a disputa entre o Teatro Oficina e o Grupo Silvio Santos e esse território não pode ser pensado de forma isolada do contexto no qual está inserido. Claramente, o parque faz parte de um conjunto patrimonial da cidade que deve ser preservado e que tem sido ameaçado física e simbolicamente. É o caso do TBC, por exemplo, que representa um importante lugar de memória do bairro e está totalmente abandonado e esquecido pelo poder público. Ou dos jardins da Casa de Dona Yayá, sendo estes o último resquício da vegetação originária do bairro, e que teria sua paisagem muito comprometida com a possível construção das torres do Silvio Santos. Dessa forma, qualquer proposta para aquele espaço deveria ter a intenção de articular física e simbolicamente esses espaços. 
Foi então que, partindo dos estudos que compuseram essa dissertação, veio a ideia de realizar um mapeamento dos postes de luz presentes, desde da Rua Jaceguai - Teatro Oficina e Parque Bixiga - até a Rua Major Diogo na altura do TBC, e pensar uma intervenção para esses postes. Ao todo são 5 postes na Jaceguai e mais 3 postes na Major Diogo até o TBC. Os postes que estão localizados em cima do Elevado e que são responsáveis pela iluminação da curva que a Jaceguai faz até a Casa de Dona Yayá não foram considerados, pois fazem parte de uma outra camada de iluminação - tem características específicas - e integram a malha viária da cidade.

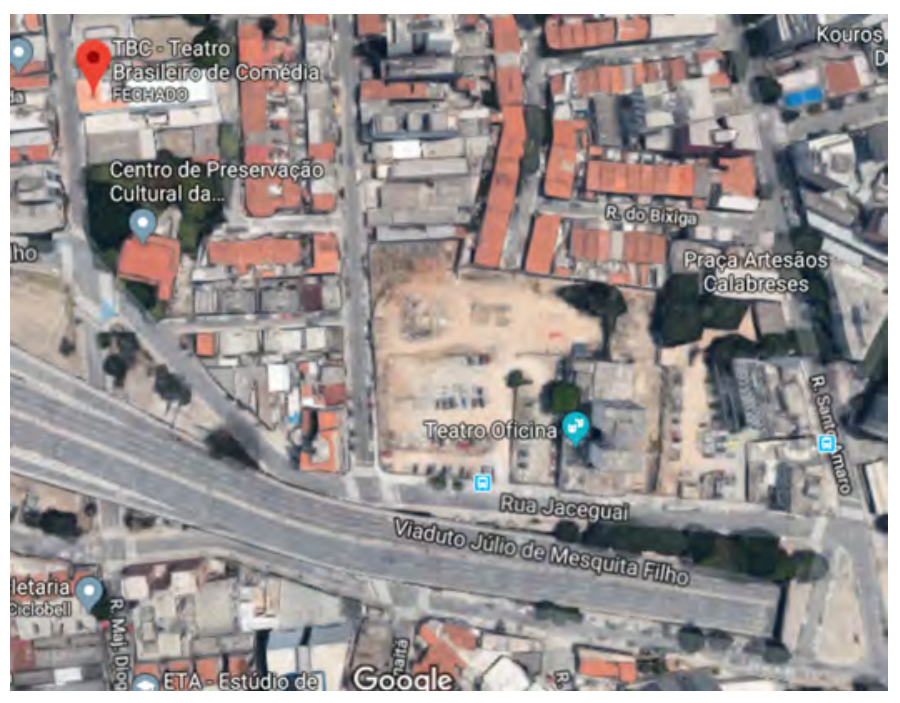

FONTE: https://www.google.com.br/maps

A partir desse recorte comecei a pensar qual tipo de intervenção poderia articular uma possível ponte entre os objetos em questão, e que pudesse trazer isso para o nível simbólico. E nesse sentido resgatarei aqui um pouco do simbolismo envolto na figura do Arco-Íris, desde o sentido mais profundo e mitológico de ponte entre dois planos, que remonta à Goethe e à tensão entre luz e sombra, até o sentido mais prosaico, enquanto símbolo da luta política LGBT. Portanto, pouco a pouco, a ideia de projetar um Arco-Íris - a partir dos postes públicos - desde a Jaceguai até a Major Diogo foi ganhando cada vez mais força. 0 desejo seria então cobrir a luz dos postes com filtro de cor, como foi feito por Guilherme Bonfanti no espetáculo Bom Retiro. Porém, diferentemente do que Bonfanti fez, meu objetivo não seria construir traquitanas de caráter permanente e sim criar uma proposta mais efêmera com traquitanas mais leves que possam ser fixadas rapidamente através de corda. Ou seja, gostaria que essa ação de colocar as traquitanas tivesse uma dimensão performática. 
Outra questão que surgiu a partir do mapeamento dos postes é a escuridão da curva da Rua Jaceguai e dos baixios do Minhocão - desde a esquina da Rua Abolição até a Casa de Dona Yayá - que somente conta com os postes acima do Elevado. Assim o projeto acabou se desenvolvendo para que desde o primeiro poste da Jaceguai, próximo à Praça Pérola Byington, ao longo dos cinco postes da rua até o último, em frente ao Parque do Bixiga, se formasse um transição de cor desde o violeta até o amarelo. E a partir do amarelo do parque, em referencia às latas de fogo de Hélio Oiticica, fossem acesas latas de fogo no Baixio do Minhocão, desde a Rua Abolição até a Casa de Dona Yayá; de forma que o fogo iluminasse a sombra projetada por aquela construção. Até que então na Rua Major Diogo, nos primeiros 3 postes de luz da rua, se desse uma sequência de um amarelo alaranjado até finalizar com o vermelho, em frente do TBC. Outra ideia para compor a intervenção seria a instalação de uma chapa metaloide fina em cada poste, para que dançasse ao vento produzindo um ruído que remetesse ao barulho de um rio.

Meu objetivo inicial era realizar essa intervenção antes do depósito dessa dissertação. No entanto, devido ao contexto politico e social da cidade hoje e aos desafios materiais para a realização da intervenção, optei por investir na concepção material do projeto. Nesse sentido, considerando a importância conceitual de Hélio Oiticica para a pesquisa, decidi pela construção de uma maquete.

\footnotetext{
"À medida, porém, que a arquitetura vai-se tornando não-objetiva, "abstrata", o espaço passa a crescer de importância. Assim, para mim, quando realizo maquetas ou projetos de maquetas, labirintos por excelência, quero que a estrutura arquitetônica recrie e incorpore o espaço real num espaço virtual, estético, e num tempo, que é também estético. Seria a tentativa de dar ao espaço real um tempo, uma vivência estética, aproximando-se assim do mágico, tal o seu caráter vital. (...) 0 labirinto porém, como labirinto, ainda é a idéia abstrata mais próxima da arquitetura estática no espaço. (...) Seria portanto a ponte para uma arquitetura espacial, ativa, ou espácio-temporal. (...) Esses sulcos são como "regados pelo espaço" (...) 0 espaço e o tempo se casam em definitivo. " (OITICICA, 1986, p.26)
}

Me pareceu ser mais produtivo, ao invés de tentar realizar a performance a qualquer custo e de forma precária, investir da elaboração conceitual da mesma. Acredito que esse processo vai permitir que ela ganhe potência, a partir da a articulação de todas as camadas simbólicas intencionadas, e sigo almejando a possibilidade de realiza-la em um futuro próximo, com condições materiais adequadas. De todo modo a construção da maquete foi 
uma oportunidade maravilhosa de pensar a totalidade da proposta e, depois de finalizada, esta tornou-se em si um objeto muito interessante, onde a arquitetura dos prédios que a intervenção pretende dialogar ganham uma dimensão gigante. Algumas questões cruciais, me parece, são com ela amplificadas, como, por exemplo, a conexão que existe entre o tecido verde do jardim da Casa de Dona Yayá e o que significaria um futuro parque. Ou por exemplo o protagonismo do Minhocão naquela arquitetura urbana.

No caso dessa proposta ser realizada, o contexto material e simbólico que irá possibilitar a sua realização por certo direcionará bastante a maneira com que as traquitanas serão colocadas e toda a performance que fará parte da realização. Minha intenção é que isso aconteça a partir da articulação entre os objetos e as forças presentes naquele território e com as quais o trabalho pretende dialogar. A ideia inicial é que a performance comece na Rua Jaceguai, desça passando pelos baixios do Minhocão, pelos jardins de Yayá até o TBC para depois ser finalizada no Parque. Seria bonito se os performers pudessem, eles mesmos, subir as traquitanas nos postes por meio de corda e que houvesse música que dialogasse com os ruídos produzidos pelo metaloides que também estarão sendo instalados. 0 horário ideal para realização do trabalho é no fim da tarde, passando pelo crepúsculo até a noite. A ideia de trazer a simbologia do arco-íris tem também a ver com a tentativa de se estabelecer uma ponte entre dois opostos, dois planos, sendo nesse caso pertinente que ele apareça entre o dia e a noite. 

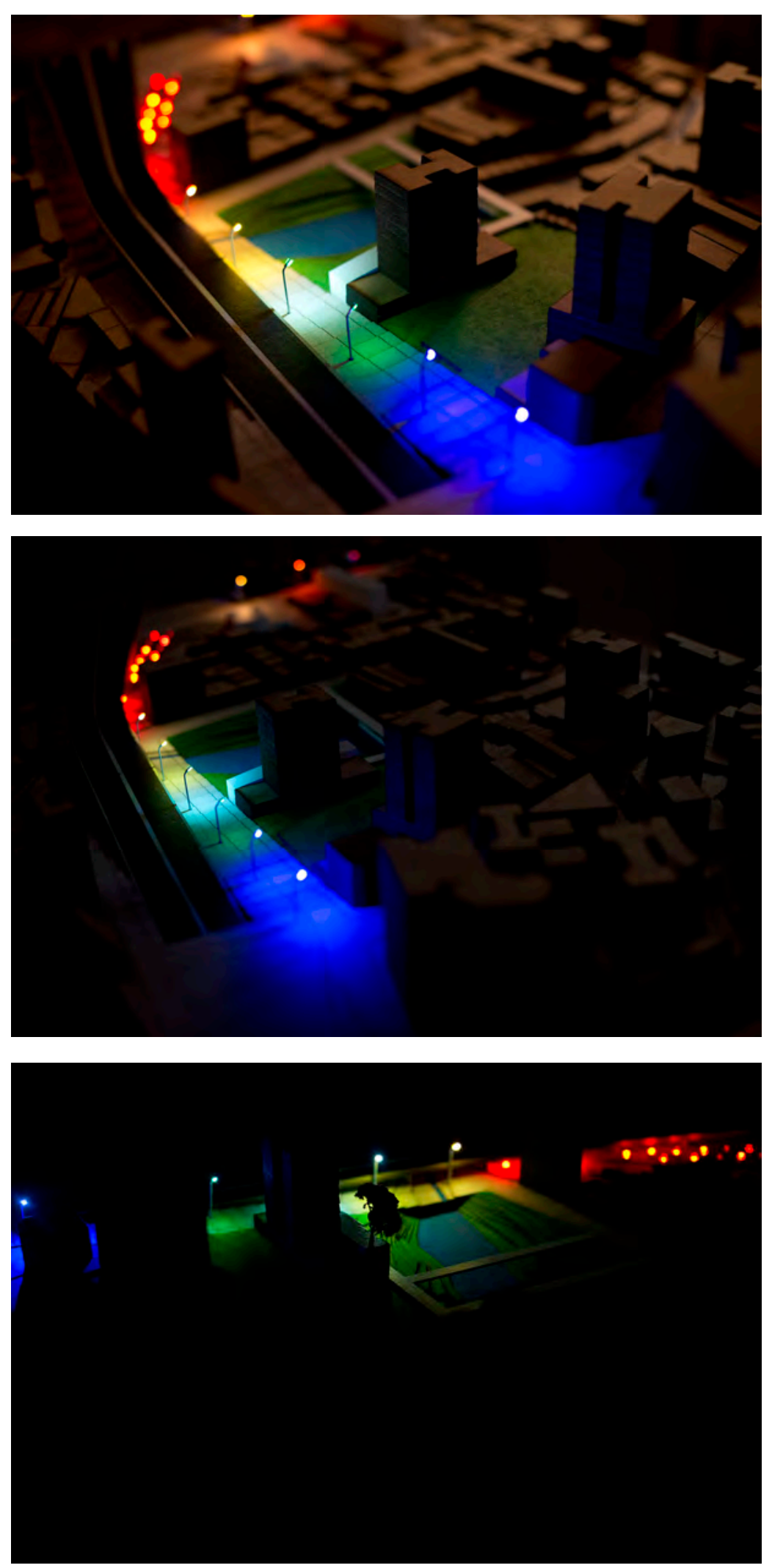

Maquete Arco-Iris da Feliz Cidade, 2019.

Concepção: Lúcia Galvão

Construção: Guilherme Tanaka

Foto: Emiliano Capozoli 

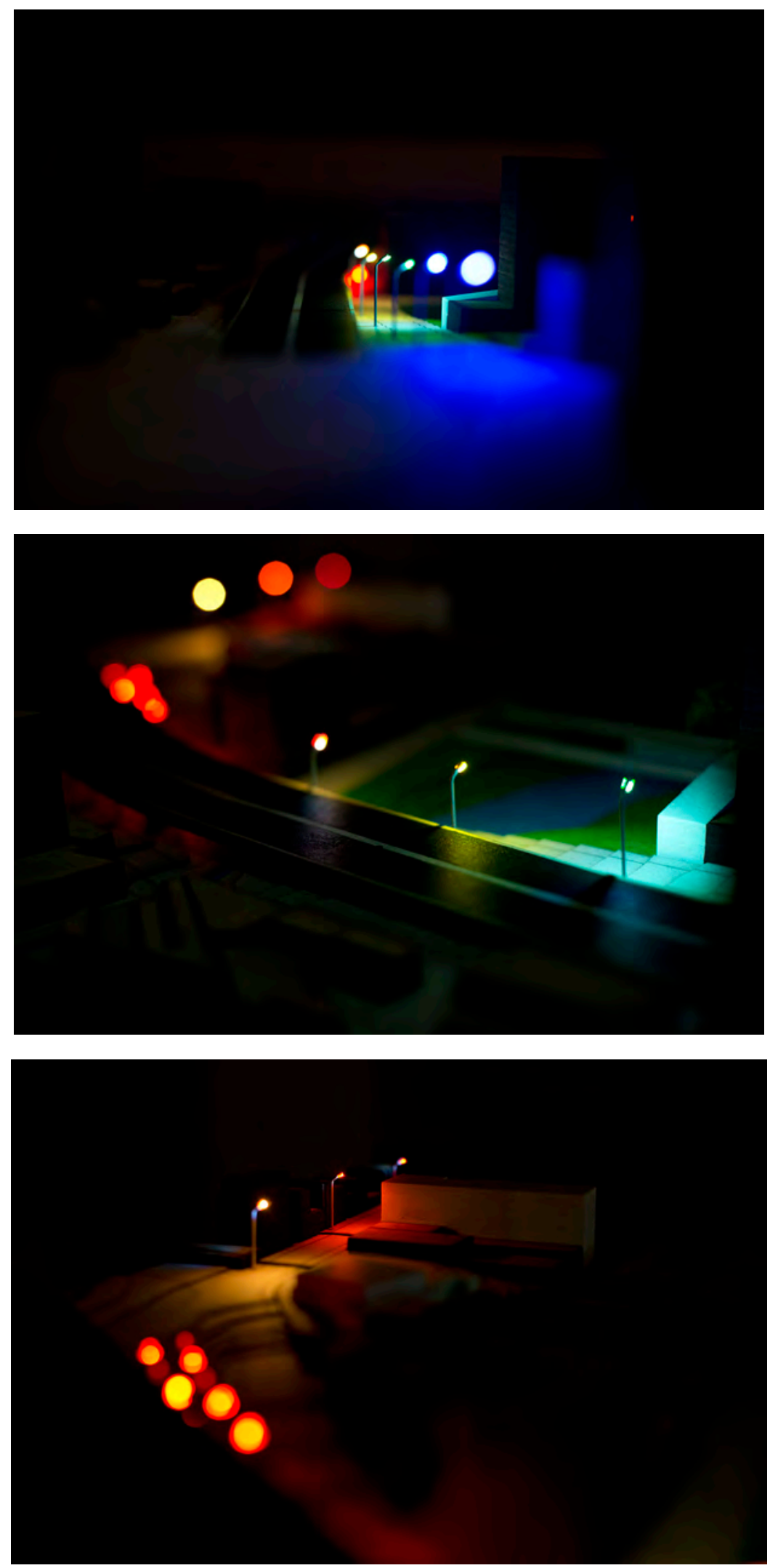

Maquete Arco-Iris da Feliz Cidade, 2019.

Concepção: Lúcia Galvão

Construção: Guilherme Tanaka

Foto: Emiliano Capozoli 

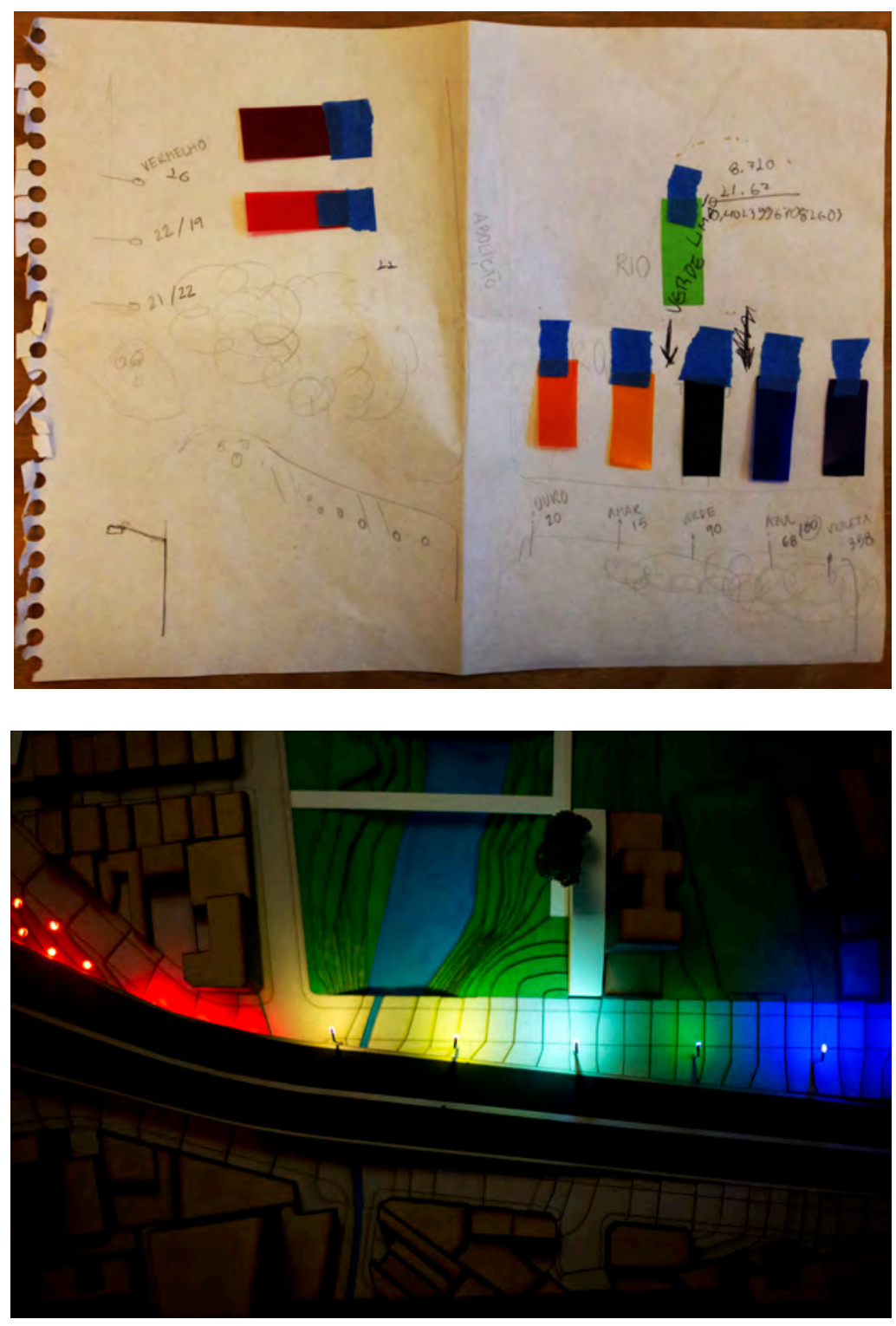

Maquete Arco-Iris da Feliz Cidade, 2019.

Concepção: Lúcia Galvão

Construção: Guilherme Tanaka

Foto: Emiliano Capozoli 


\section{CONSIDERAÇÕES FINAIS}

Ao longo da dissertação pretendeu-se investigar o potencial performativo da luz dentro do contexto de intervenções urbanas e, para o desenvolvimento desse percurso, foram escolhidos alguns artistas brasileiros que trabalharam essa questão com propostas de trabalho muito diferentes, e no entanto muito próximas. 0 primeiro capítulo se empenhou em situar essa noção de luz performática - o objeto principal de toda a pesquisa - a partir das proposições conceituais de Hélio Oiticica e tendo como embasamento teórico fundamental a "Doutrina da Cores" de Goethe. A escolha de aproximar a pesquisa às reflexões de Oiticica está relacionada à dimensão "ambiental” e política que ele agrega à suas investigações e que parecem muito apropriadas para ancorar as noção de luz e cor no contexto de intervenções urbanas.

Partindo, desde o principio, da vontade de retomar uma análise de intervenções que realizei na cidade de São Paulo, a escolha foi trazer luz à artistas e obras que buscavam dialogar com o espaço urbano a partir do uso performático da cor e da luz. A escolha das obras de Eleonora Fabião e Guilherme Bonfanti se deu justamente porque ambos encontram soluções extremamente poéticas - a partir da luz e da cor - para dialogarem com questões ambientais, politicas e simbólicas dos espaços aonde se inserem. Existe um uso da luz que independe de que a ação esteja inserida no campo da performance ou do teatro. Além disso existe um tipo de escolha artística também feita por ambos que se relaciona com o contexto material de onde essas ações acontecem e se traduzem em traquitanas e apropriações muito interessantes.

Não há dúvida que esse recorte não encerra o campo gigante em que muitos outros artistas poderiam estar citados, a saber: Carmela Gross, Lucia Koch, LuzInterruptos, Paulinho Fluxux, entre outros. Certamente ainda resta muito o que escrever e pensar sobre o assunto, principalmente no contexto acadêmico brasileiro, em que os estudos sobre iluminação ainda estão encontrando seu espaço. Essa dissertação pretende apenas abrir uma discussão sobre as questões mais específicas da iluminação no âmbito das relações que a arte pode estabelecer com o meio social em que está inserida. Escolhi alguns artistas para dialogar, a partir das minhas próprias intervenções, porque me parece que cor e luz desempenham poderosas armas de ressignificação do meio social.

Por fim, sobre a proposta pretendida para o bairro Bixiga, e que pretende afinar-se com a luta pelo Parque do Bixiga - que está na iminência de ser aprovado pela prefeitura é importante chamar atenção para a situação de risco em que alguns lugares de memória do bairro se encontram. Eles vem sofrendo a partir de uma violenta especulação imobiliária, que deixa de considerar muitos elementos simbólicos e materiais pertencente àquela paisagem. 


\section{BIBLIOGRAFIA}

\section{Livros e revistas}

BARROS, Anna. A arte da percepção: um namoro entre a luz e o espaço. São Paulo: Annablumme; Fapesp. 1999.

CASTRO, Márcio Sampaio de. Bexiga: um bairro afro-italiano. São Paulo: Annablume, 2008.

CERTEAU, Michel de. A invenção do Cotidiano-1:Artes de Fazer. Petrópolis: Ed. Vozes, 1994.

DEBORD, Guy. A sociedade do espetáculo; tradução Estela dos Santos Abreu. Rio de Janeiro: Contraponto, 2017.

FABIÃO, Eleonora. Ações: Eleonora Fabião; org. Eleonora Fabião, Andre Lepecki. Rio de Janeiro: Tamanduá Arte, 2015.

FABIÃO, Eleonora. azul azul azul e azul In: Das Virgens em Cardumes e a Cor das Auras (org.) Daniela Labra_São Paulo: WMF Martins Fontes, 2017.

FABIÃO, Eleonora. Performance e teatro: poéticas e políticas da cena contemporânea. Revista Sala Preta, PPGAC-USP, v.8, 2008.

FABIÃO, Eleonora. Performance e teatro: poéticas e políticas da cena contemporânea. Revista Próximo Ato: Teatro de Grupo. Org: Antônio Araujo, José Fernando Peixoto de Azevedo e Maria Tendlau. São Paulo: Itaú Cultural, 2011.

FABIÃO, Eleonora. The Archive of Everything that Exists in the World In: Infinite Record: archive, memory, performance (org.) Karmenlara Ely and Maria Magdalena Schwaegermann. New York: Brooklyn Arts Press, 2016.

GOTHE, J. W. Doutrina das Cores. São Paulo: Ed. Nova Alexandria, 1993.

GRÜNSPUN, Haim. Anatomia de um Bairro: o Bexiga. São Paulo: Livraria Cultura, 1979. 
HARDIN, C.L. Color for Philosophers: Unweaving the Rainbow. Indianapolis: Hackett Publishing Company, 1988.

HARVEY, David. Condição Pós-Moderna: Uma pesquisa sobre as Origens da Mudança Cultural. Tradução: Adail Ubirajara Sobral e Maria Stela Gonçalves. 25 ed. São Paulo: Edições Loyola.

HIKIJI, Rose S. G.; SILVA, Adriana de Oliveira (orgs.) Bixiga em Artes e Ofícios. São Paulo: Editora da Universidade de São Paulo: Edusp, 2014.

ITAÚ CULTURAL. Hélio Oiticica: museu é o mundo. - São Paulo: Itaú Cultural, 2010.

KELLER, Max. Light Fantastic: the art and design of stage lighting. Munich; London; New York: Prestel 1999

KLEIN, Yves. Overcoming the problematics of art: the writings of Yves Klein; translated, with an introduction by Klaus Ottmann. Paris: Spring Publications, 2007.

KWON, Miwon. One place after another: site- specific art and locational identity. Massachysetts Institute of Technology, 2002.

LEFEBVRE, Henri. A Vida Cotidiana no Mundo Moderno. Tradução: Alcides João de Barros. São Paulo: Editora Ática, 1991.

LUCENA, Célia Toledo. Bairro do Bixiga: a sobrevivência cultural. São Paulo: Brasiliense, 1984.

MAHNKE, Frank H. Color, Environment \& Human Rensponse. NY: Van Nostrand Reinhold, 1996.

MERLEU-PONTY, Maurice. Fenomenologia da Percepção. São Paulo: Livraria Martins Fontes Editora Ltda, 2011.

MERLEU-PONTY, Maurice. 0 olho e o espírito: seguido de A linguagem indireta e as vozes do silêncio e A dúvida de Cézanne; tradução Paulo Neves e Maria Ermantina Galvão Gomes Pereira; prefácio Claudio Lefort; posfácio Alberto Tassinari_São Paulo: Cosac e Naify, 2004. 
OITICICA, Hélio. Aspiro ao grande labirinto. Rio de Janeiro: Rocco, 1986.

PALLAMIN, Vera. Arte, cultura e cidade: aspectos estético-políticos contemporâneos. São Paulo: Annablume, 2015.

PEDROSA, Israel. Da cor à cor inexistente. Rio de Janeiro: Senac Nacional, 2014.

CORDEIRO, Graça Índias. A cidade e a escala da rua: usos e significados do passado na afirmação de 'tradições locais e urbanas

DOLFF- BONAKÄMPER, Gabi. Caminhando pelo passado dos outros. Tradução: Carlos Szlak.

FREHSE, Fraya. Memória e Espaço.

In Patrimônio Cultural: memórias e intervenções humanas. Org: Renato Cymbalista, Sarah Feldman, Beatriz M. Külh. São Paulo: Annablume: Núcleo de Apoio e Pesquisa São Paulo, 2017.

RANCIÈRE, Jacques. A partilha do sensível: estética e política; tradução de Mônica Costa Netto. São Paulo: EXO experimental org.; Editora 34, 2009.

ALBUQUERQUE, Johana. Bom Retiro: 958 metros de política na poética.

OLIVEIRA,Luís Fabiano e BALESTRERI, Silvia. Deambulações situacionistas em Bom Retiro 958 metros.

MEICHES, Mauro Pergaminik. Bom Retiro 958 metros - geografia da memória e memória poética.

NÉSPOLI, Elizabeth Maria. Recepção - Teatro da Vertigem:Uma poética do corpo e suas interações sociais.

GOES, Marta. Bom Retiro.

CALDAS, Miguel. Desenho de Som - Bom Retiro 136 Quilômetros. 
In Revista Sala Preta, v.12, n.2. Dossiê Bom Retiro: 958 metros - 0 acontecimento: olhares sobre o Vertigem. PPGAC-USP, 2012.

RIOUT, Denys. Yves Klein Expressing the Immaterial. Paris: Éditions Dilecta, Paris, 2010.

SANTOS, Milton. A Natureza do Espaço: Técnica e Tempo, Razão e Emoção. São Paulo: Editora Universidade de São Paulo, 2014.

ZAJONC, Arthur. Catching the Light: The Entwined History of Light and Mind. New York, Oxford University Press, 1993.

WESCHELER, Lawrence. Seeing is forgetting the name of the thing one sees: over thirty years of conversations with Robert Irwin. California, University of California Press, 2008.

\section{Teses e dissertações}

BERTUCCI, Patricia Morales. Intervenção Urbana, São Paulo (1978-1982): o espaço da cidade e os coletivos de arte independente Viajou Sem Passaporte e 3 Nós 3. São Paulo: ECA/USP, 2015.

GONÇALVES, Camila Teixeira. Intervenções contemporâneas no Bixiga: fissuras urbanas e insurgências. Dissertação de Mestrado. São Carlos: Instituto de Arquitetura e Urbanismo da Universidade de São Paulo, 2016.

KOCH, Lucia Machado. Estados Alterados do Lugar. Tese de Doutorado. São Paulo: ECA/USP, 2013.

NÉSPOLI, Elizabeth Maria. Teatro da Vertigem: Construção Poética e Recepção. Estudo do campo de tensão que se instaura no encontro da proposição artística com seus receptores. Tese (Doutorado) - Escola de Comunicações e Artes, Universidade de São Paulo, São Paulo, 2015. 


\section{Textos encontrados na internet}

BRAGA, Paula. A cidade, a política e a mutação da arte. Entre Hélio Oiticica e Cripta Djan. Arquitextos, São Paulo, ano 18, n. 208.03, Vitruvius, set. 2017 <https://www.vitruvius.com.br/ revistas/read/arquitextos/18.208/6720>.

FERNANDES, Gabriel; CAMARGO, Mônica Junqueira de. A Casa de Dona Yayá na preservação do Bexiga. Minha Cidade, São Paulo, ano 18, n. 209.01, Vitruvius, dez. 2017 <https://www.vitruvius. com.br/revistas/read/minhacidade/18.209/6796>.

GALLMEISTER, Marília; MATZENBACHER, Carila. 0 talento cultural do Bixiga \& o Anhangabaú da Feliz Cidade. Minha Cidade, São Paulo, ano 15, n. 180.05, Vitruvius, jul. 2015 <http://vitruvius.com.br/revistas/read/minhacidade/15.180/5617>.

LOEB, Angela Varela. Os Bólides do programa ambiental de Hélio Oiticica. ARS (São Paulo) vol.9 no.17 São Paulo 2011. <http://dx.doi.org/10.1590/S1678-53202011000100004 >

TEATRO Oficina. In: ENCICLOPÉDIA Itaú Cultural de Arte e Cultura Brasileiras. São Paulo: Itaú Cultural, 2019. Disponível em: <http://enciclopedia.itaucultural.org.br/grupo112413/teatrooficina>. Acesso em: 06 de Set. 2019. Verbete da Enciclopédia.

ISBN: 978-85-7979-060-7

ANTROPÓFAGA, Universidade. 0 Parque do Bixiga é da cidade.

Universidade Antropófaga, 2017. Disponível em: <https://medium.com/@ uniantropofaga/o-parque-do-bixiga-\%C3\%A9-nosso-66162493bed8>

\section{Sites}

http://guilhermebonfanti.com.br/22/bom-retiro-relatos-da-luz/ http://www.premiopipa.com/pag/artistas/eleonora-fabiao/ http://www.premiopipa.com/2018/03/conversa-com-eleonora-fabiao-por-luiz-camillo-osorio/ http://www.teatrodavertigem.com.br/ https://www.universidadeantropofaga.org/ http://teatroficina.com.br/ 